Chemical Technology Division

\title{
A LITERATURE REVIEW OF MIXED WASTE COMPONENTS: SENSITIVITIES AND EFFECTS UPON SOLIDIFICATION/STABILIZATION IN CEMENT-BASED MATRICES
}

C.H. Mattus

T.M. Gilliam

Date Published: March 1994
Prepared for the U.S. DEPARTMENT OF ENERGY OFFICE OF TECHNOLOGY DEVELOPMENT
Washington, D.C. 20585

Prepared by the

OAK RIDGE NATIONAL LABORATORY

Oak Ridge, Tennessee 37831-6285 managed by

MARTIN MARIETTA ENERGY SYSTEMS, INC. for the

U.S. DEPARTMENT OF ENERGY under contract DE-AC05-84OR21400 
CONTENTS

Page

LIST OF TABLES $\ldots \ldots \ldots \ldots \ldots \ldots \ldots \ldots \ldots \ldots \ldots \ldots \ldots \ldots \ldots$

ABBREVIATIONS AND CHEMICAL SYMBOLS $\ldots \ldots \ldots \ldots \ldots \ldots \ldots$ vi

EXECUTIVE SUMMARY $\ldots \ldots \ldots \ldots \ldots \ldots \ldots \ldots \ldots \ldots \ldots \ldots \ldots$

1. INTRODUCTION $\ldots \ldots \ldots \ldots \ldots \ldots \ldots \ldots \ldots \ldots \ldots \ldots \ldots$

2. HYDRATION MECHANISMS OF PORTLAND CEMENT $\ldots \ldots \ldots \ldots \ldots$

3. MECHANISMS OF RETARDATION AND ACCELERATION OF CEMENT SET-FACTORS AFFECTING THE DURABILITY OF WASTE FORMS . . . 12

3.1 ACCELERATING ADMIXTURES $\ldots \ldots \ldots \ldots \ldots \ldots \ldots \ldots \ldots \ldots \ldots$

3.1.1 Admixtures Accelerating $\mathrm{C}_{3}$ S Hydration $\ldots \ldots \ldots \ldots \ldots \ldots \ldots \ldots$

3.1.2 Admixtures Accelerating $\mathrm{C}_{3} \mathrm{~A}$ Hydration $\ldots \ldots \ldots \ldots \ldots \ldots \ldots$

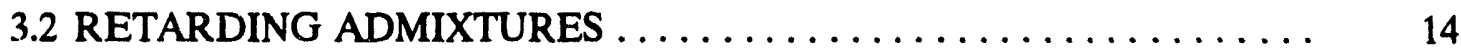

3.2.1 Admixtures Retarding $\mathrm{C}_{3} \mathrm{~S}$ Hydration $\ldots \ldots \ldots \ldots \ldots \ldots \ldots \ldots \ldots \ldots$

3.2.2 Admixtures Retarding $\mathrm{C}_{3} \mathrm{~A}$ Hydration $\ldots \ldots \ldots \ldots \ldots \ldots \ldots \ldots$

3.3 DURABILITY OF WASTE FORMS $\ldots \ldots \ldots \ldots \ldots \ldots \ldots \ldots \ldots$

4. REGULATORY LIMITS AS THEY APPLY TO MIXED WASTES . . . . . 18

5. REVIEW OF INORGANIC SPECIES THAT INTERFERE WITH

THE DEVELOPMENT OF CEMENT-BASED WASTE FORMS . . . . . . 22

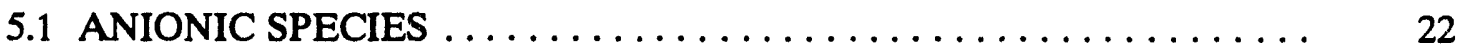

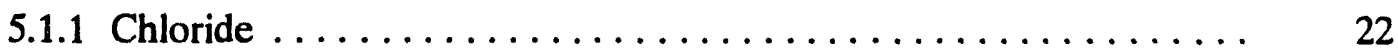

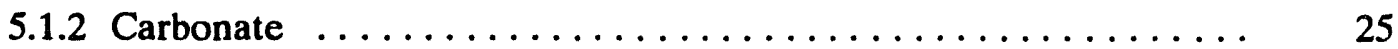

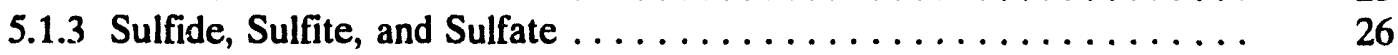

5.1 .4 Nitrate and Nitrite ..................... 31

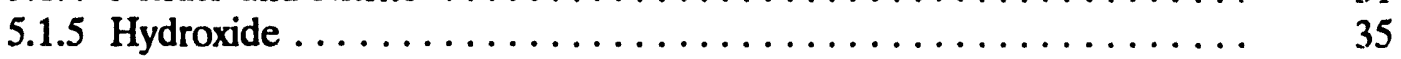

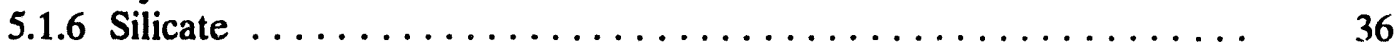

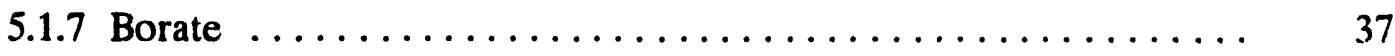

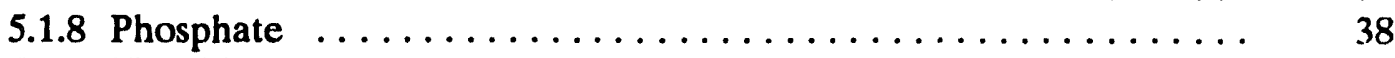

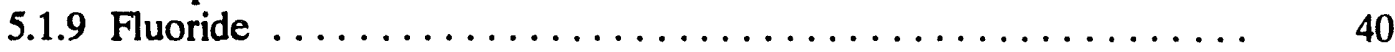

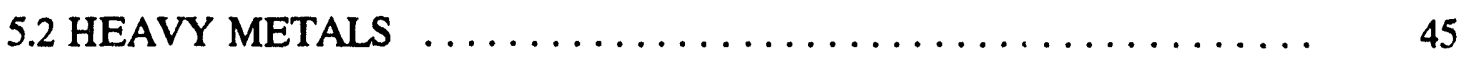

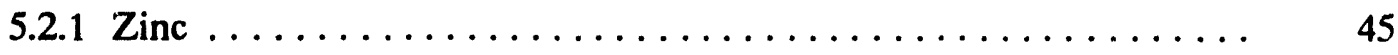

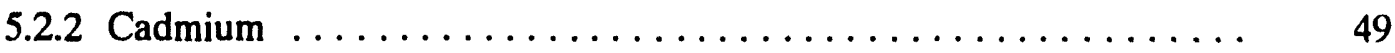




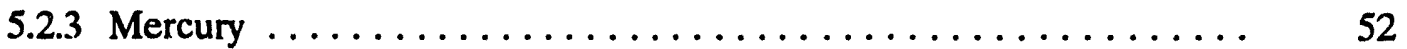

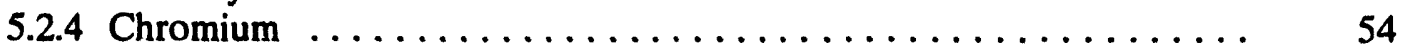

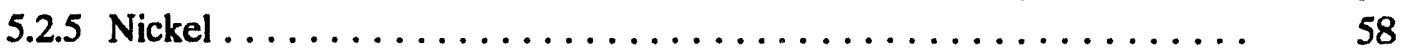

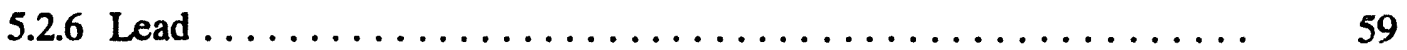

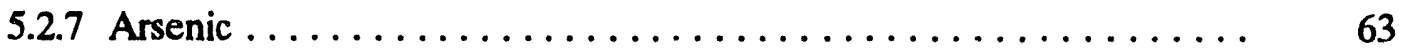

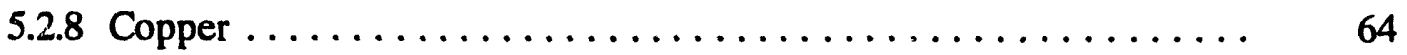

5.2.9 Other RCRA Metals: Barium, Selenium, and Silver $\ldots \ldots \ldots \ldots \ldots 6$

5.3 OTHER SPECIES $\ldots \ldots \ldots \ldots \ldots \ldots \ldots \ldots \ldots \ldots \ldots \ldots \ldots \ldots$

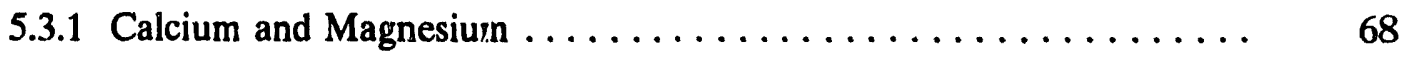

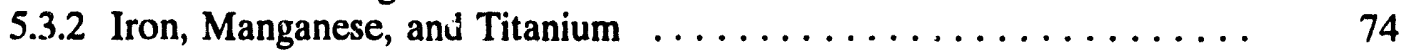

5.3.3 Thallium, Antimony, Beryllium, Vanadium, and Molybdenum ..... 75

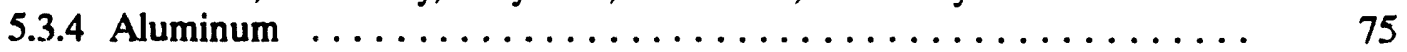

5.3.5 Sodium, Lithium, and Potassium ............... 76

6. REVIEW OF RADIOACTIVE SPECIES THAT CAN BE IMMOBILIZED IN CEMENT-BASED WASTE FORMS $\ldots \ldots \ldots \ldots \ldots \ldots \ldots \ldots \ldots \ldots \ldots$

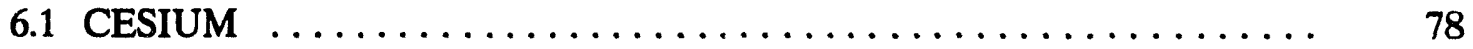

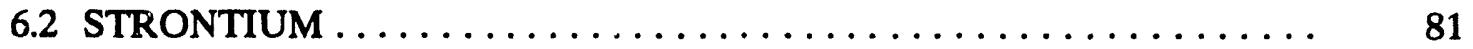

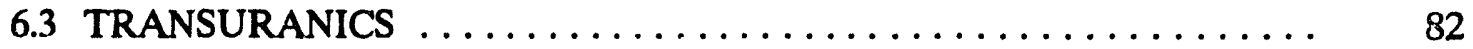

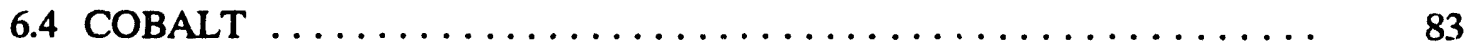

6.5 TECHNETIUM $\ldots \ldots \ldots \ldots \ldots \ldots \ldots \ldots \ldots \ldots \ldots \ldots \ldots \ldots \ldots$

7. REVIEW OF ORGANIC SPECIES THAT MAY INTERFERE

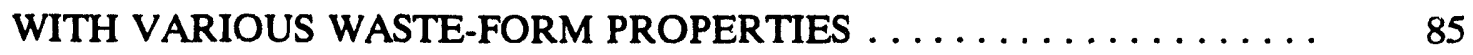

8. SUMMARY AND CONCLUSIONS $\ldots \ldots \ldots \ldots \ldots \ldots \ldots \ldots \ldots \ldots \ldots \ldots$

8.1 GENERAL CHARACTERIZATION $\ldots \ldots \ldots \ldots \ldots \ldots \ldots \ldots \ldots$

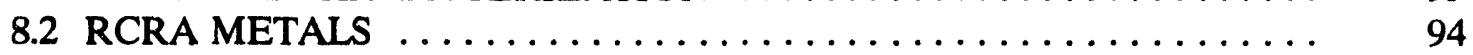

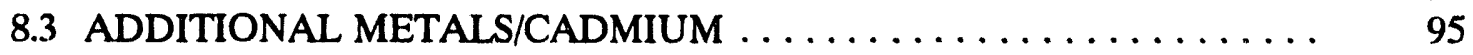

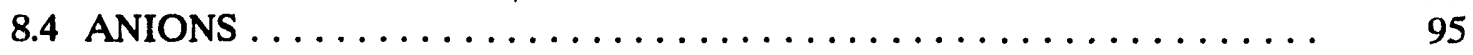

8.5 U.S. DEPARTMENT OF TRANSPORTATION REGULATIONS . . . . 95

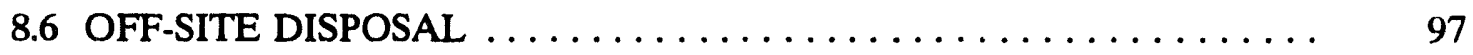

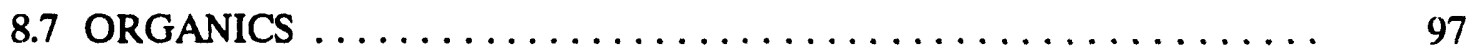

8.8 QUALITY ASSURANCE $\ldots \ldots \ldots \ldots \ldots \ldots \ldots \ldots \ldots \ldots \ldots \ldots \ldots \ldots$

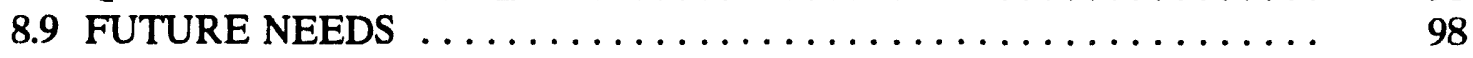

REFERENCES $\ldots \ldots \ldots \ldots \ldots \ldots \ldots \ldots \ldots \ldots \ldots \ldots \ldots \ldots \ldots \ldots \ldots$ 


\section{LIST OF TABLES}

ES.1 Waste characterization data required to support the development of grout waste forms

1. Summary data of anionic waste species

2. Summary data of metallic waste species

3. Waste characterization data required to support the development of grout waste forms 


\section{ABBREVIATIONS AND CHEMICAL COMPOUNDS}

BFS

BWR

$\mathrm{C}_{3} \mathrm{~A}$

$\mathrm{C}_{4} \mathrm{AF}$

$\mathrm{C}_{4} \mathrm{AH}_{13}$

$\mathrm{C}_{2} \mathrm{AH}_{8}$

$\mathrm{C}_{3} \mathrm{AH}_{6}$

$\mathrm{C}_{2} \mathrm{AH}_{6}$

$\mathrm{C}_{3} \mathrm{~A} \cdot 3 \mathrm{CaSO}_{4} \cdot 32 \mathrm{H}_{2} \mathrm{O}$

$\mathrm{C}_{3} \mathrm{~A} \cdot \mathrm{CaSO}_{4} \cdot 12 \mathrm{H}_{2} \mathrm{O}$

$\mathrm{C}_{3} \mathrm{~A} \cdot \mathrm{CaCl}_{2} \cdot 10 \mathrm{H}_{2} \mathrm{O}$

$\mathrm{CaCO}_{3} \cdot \mathrm{CaSO}_{4} \cdot \mathrm{CaSiO}_{5} \cdot 15 \mathrm{H}_{2} \mathrm{O}$

$\mathrm{CaCO}_{3}$

$\mathrm{C}_{2} \mathrm{~S}$

$\mathrm{C}_{3} \mathrm{~S}$

$\mathrm{CaSO}_{4} \cdot 2 \mathrm{H}_{2} \mathrm{O}$

$\mathrm{CaSO}_{4} \cdot 1 / 2 \mathrm{H}_{2} \mathrm{O}$

$\mathrm{CaSO}_{4}$

$\mathrm{CH}$

CSH

DDT\&E

DOE

DOT

DSSF

DTA

EDTA

EP

EPA

FFCA

FTIR

ICP

INEL

LDR

NRC

OPC

ORR

PCB

PCP

PFA

PWR

RCRA blast furnace slag

boiling-water reactor

tricalcium aluminate $\left(3 \mathrm{CaO} \cdot \mathrm{Al}_{2} \mathrm{O}_{3}\right)$

calcium aluminoferrite $\left(4 \mathrm{CaO} \cdot \mathrm{Al}_{2} \mathrm{O}_{3} \cdot \mathrm{Fe}_{2} \mathrm{O}_{3}\right)$

tetracalcium aluminate hydrates $\left(4 \mathrm{CaO} \cdot \mathrm{Al}_{2} \mathrm{O}_{3} \cdot 13 \mathrm{H}_{2} \mathrm{O}\right)$

dicalcium aluminate hydrates $\left(2 \mathrm{CaO} \cdot \mathrm{Al}_{2} \mathrm{O}_{3} \cdot 8 \mathrm{H}_{2} \mathrm{O}\right)$

tricalcium aluminate hydrates $\left(3 \mathrm{CaO} \cdot \mathrm{Al}_{2} \mathrm{O}_{3} \cdot 6 \mathrm{H}_{2} \mathrm{O}\right)$

dicalcium aluminate hydrates $\left(2 \mathrm{CaO} \cdot \mathrm{Al}_{2} \mathrm{O}_{3} \cdot 6 \mathrm{H}_{2} \mathrm{O}\right)$

ettringite

calcium monosulfoaluminate

calcium chloroaluminate

thaumasite

calcite

dicalcium silicate $\left(2 \mathrm{CaO} \cdot \mathrm{SiO}_{2}\right)$

tricalcium silicate $\left(3 \mathrm{CaO} \cdot \mathrm{SiO}_{2}\right)$

gypsum

hemihydrate

anhydrite

calcium hydroxide or portlandite $\left[\mathrm{Ca}(\mathrm{OH})_{2}\right]$

calcium silicate hydrates

development, demonstration, testing, and evaluation

U.S. Department of Energy

U.S. Department of $T_{l}$ insportation

double-shell slurry feed

differential thermogravimetrical ar alysis

ethylene diaminetetraacetic

Extraction Procedure

U.S. Environmental Protection Agency

Federal Facility Compliance Agreement

Fourier transform infrared

inductively coupled plasma-atomic emission

spectroscopy

Idaho National Engineering Laboratory

land disposal restriction

U.S. Nuclear Regulatory Commission

ordinary portland cement

Oak Ridge Reservation

polychlorinated biphenyl

pentachlorophenyl

pulverized fuel ash

pressurized-water reactor

Resource Conservation and Recovery Act 


\section{ABBREVIATIONS AND CHEMICAL COMPOUNDS (Continued)}

SEM

S/S

TCB

TCE

TCLP

TCP

TEA

TGA

UCS

VOC scanning electron microscope

solidification/stabilization

trichlorobenzene

trichloroethylene

Toxicity Characteristic Leaching Procedure

trichlorophenol

triethanolamine

thermogravimetrical analysis

unconfined compressive strength

volatile organic compound 


\section{EXECUTTVE SUMMARY}

On June 12, 1992, the U.S. Department of Energy (DOE) Oak Ridge Field Office signed a Federal Facility Compliance Agreement (FFCA) with the U.S. Environmental Protection Agency Region IV regarding Oak Ridge Reservation (ORR) mixed wastes subject to the land disposal restriction (LDR) provisions of the Resource Conservation and Recovery Act (RCRA). The LDR FFCA establishes an aggressive schedule for conducting treatability studies and developing treatment methods for those ORR mixed (radioactive and hazardous) wastes listed in Appendix B to the Agreement. These are wastes for which treatment methods and capabilities have yet to be defined. Compliance with Requirement 5 of the Agreement states that

... DOE shall submit to EPA for review and approval a plan for the treatment of the LDR prohibited wastes identified in Appendices 1B, 2B, and 3B. This plan must identify the treatment strategy for such wastes to meet LDR treatment standards and must include a schedule, not to exceed two (2) years after the submittal of this plan (i.e., March 1995), for the evaluation and prioritization of treatment method options, treatability studies if required, and technology development.

At a higher level, this requirement was satisfied by the DOE strategic plan for Appendix B Wastes ( DOE/OR-1083). In the strategic plan, the wastes are divided into two categories:

1. those wastes, listed in Appendix 1A, 2A, and 3A of the Agreement. for which treatment and facilities exist that meet the LDR standard; and

2. those wastes, listed in Appendix 1B, 2B, and 3B of the Agreement, for which no treatment methods or facilities exist that meet the LDR standards(hereafter referred to as Appendix B wastes).

A development, demonstration, testing, and evaluation (DDT\&E) program has been initiated to provide those efforts necessary to identify treatment methods for all of the wastes that meet Appendix B criteria. The DDT\&E program has assembled project teams to address treatment development needs in a variety of areas, including that of final waste forms (i.e., stabilization/solidification processes). As more definitive characterization data on the waste are obtained, any wastes newly classified as Appendix B wastes will be so identified in updates to the FFCA and will be included in treatment development programs.

In the context of this report, solidification refers to treatment that renders the waste a "solid." Solidification encompasses technologies such as filtration, drying, and calcination that remove liquid and result in a dry or "solid" residue. Coating the dry waste with a polymer or similar substance would be considered solidification within the context of this project. Stabilization, which may also involve solidification, refers to treatment which reacts with the waste constituents of concern to render them nonhazardous or convert them to a chemical form which is less hazardous. As most processes involving stabilization 
also involve solidification, they are referred to as stabilization/solidification (S/S) processes. The Final Waste Form Project will give priority to the more traditional S/S processes, but it will not exclude such technologies as filtration and drying. Waste-form types being actively considered by this project include grout (e.g., cement-based technology), glass (e.g., vitrification technology), and organic binders (e.g., polymer encapsulation). It is not clear, at present, what the final form and composition of the yet-to-be-determined treatment method residues will be and which waste streams will require, or are candidates for, $S / S$. In addition, ongoing waste characterization has not progressed to the point where potential waste candidates for $\mathrm{S} / \mathrm{S}$ can be readily identified. This process consists of reviewing existing waste records, conducting generator interviews, and performing sampling and analysis, where required, to acquire more detailed information on waste matrices and contaminants. As these data are obtained, candidate waste forms will become more apparent, and regulatory requirements for treatment of specific wastes can be clearly defined.

A comprehensive literature research has been performed, with the objective of determining waste characterization needs to support cement-based waste-form development. More specifically, the goal was to determine which waste species are problematic in term of consistent : roduction of an acceptable cement-based waste form and at what concentrations these species become intolerable. The literature search has confirmed that the knowledge of cement-based waste-form chemistry has not progressed to the point where this is possible.

Research to date in the area of cement chemistry has focused primarily on the simplest system: cement, water, and the species of interest. The majority of these studies have provided neither the definitive rationale for the mechanism of interaction between the species and the cement-water paste nor the absolute concentrations at which the interaction occurs. In addition, limited research into the synergistic effect of multiple species shows that synergistic effects definitely occur; however, the mechanism of interaction and the concentration levels remain poorly defined.

What is clear from the literature search is that cement-based waste forms, sometimes referred to as a "low-tech option," are anything but simple from the standpoint of wasteform chemistry. Indeed cement waste-form chemistry is extremely complex and is poorly understood even for the simple system of a single waste constituent in a cement-water paste. It is also clear that the following generalization can be made based upon the collective information presented in this report: the effects of any species on the cemeni. water paste chemistry are dependent upon the matrix components, the chemical form o: the species of interest, its solubility in the paste environment, and its ability to contact the: cement and, hence, interact. Consequently, quantifying the species of interest and the threshold concentration of that species in an actual waste becomes even more complex due to the nature of the waste itself. The waste is virtually never a single chemical species but is usually a complex mixture of crystalline and amorphous material composed of a variety of chemical constituents, present in soluble and/or insoluble form. The chemical form of the species of interest, the solubility of the species of interest, and the ability of the species to contact the cement are factors complicating the waste-form environment. 
The literature search has clearly established that no definitive waste characterization requirements exist. Consequently, only general guidance as to the waste constituents and concentrations of interest can be derived from available data. It is recognized that waste characterization is a costly and time-consuming endeavor. Considering the generic nature of the guidance that can be provided, it is not cost-effective to define an exhaustive list of species. More detailed characterization data needs will develop as experience is gained with each waste in laboratory-scale treatability studies.

The approach to waste characterization needs presented below is to request "screeningtype" characterization. The basic approach is to gather sufficient characterization data to know if a potential "problem species" is present and to utilize the treatability studies to determine if a problem exists. The screening data will suggest potential causes of the problem and provide guidance as to constituents requiring more detailed quantified analyses. It must be clearly understood that this approach requires that archived waste samples be maintained, so that additional analyses can be performed at a later date if required.

Waste characterization data needs have been identified that address shipping, treatability study regulations, and waste-form chemistry. It must be noted that the requested waste characterization data, summarized in Table ES.1, are generic and should be viewed as "screening-type" data. As such, sufficient quantities of waste samples should be archived so that more exhaustive characterization can be performed at a later date. Specifying the exact analytical methods for data acquisition is beyond the scope of this report as these methods will be determined by (1) analytical experience and knowledge of effective methods, (2) schedule, (3) budget, and (4) regulatory requirements. From the perspective of the Final Waste Form Project, the primary driver is that the data be technically defensible. In this regard, the assumption is made that detailed quality assurance/control requirements will be specified by the group that actually obtains the waste samples. However, the Final Waste Form Project requires, at a minimum, documentation of the following information on characterization data: procedures on sampling and analyses, confidence limits or levels, and chain of custody.

This report has focused on the minimum characterization needs, assuming that current cost and schedule constraints will not support an extensive characterization effort for all of the Appendix B wastes at this time. These screening data are sufficient only for initial "proof-of-principle" treatability studies. Ultimately a more detailed characterization will be required. These requirements will include the following:

1. The variability [concentration range (e.g., minimum and maximum)] of all hazardous constituents and radionuclides must be known, as they are the principal regulatory drivers with respect to product acceptability.

2. The variability [concentration range (e.g., minimum and maximum)] of the principal or major waste constituents $(>1 \mathrm{wt} \%)$ must be known as they will certainly dominate the waste-form chemistry and handling properties.

3. Sufficient analytical archived samples should be maintained based upon the assumption that additional characterization data, beyond that presented in this report, will have to 
be obtained, using the number of replicates defined in the analytical quality assurance plan. As development efforts are completed, both trace (minor) and major constituents of concern will be identified by experimentation. The archived samples can then be retrieved and the variability of these constituents determined.

Recognizing the cost and time involved in defining and obtaining sufficient statistically significant samples to determine the variability of waste constituents, it is a reasonable assumption that this analysis can be performed on only a limited number of Appendix B wastes in time to support the initial treatability studies. However, one should be aware of the need for this type of information, and the more detailed characterization should be obtained when feasible to do so. 
Table ES.1. Waste characterization data required to support the development of grout waste fo tos

\begin{tabular}{|c|c|c|c|c|}
\hline \multirow{2}{*}{$\begin{array}{l}\text { Characterization } \\
\text { Requirements }\end{array}$} & \multirow{2}{*}{ Section } & \multicolumn{2}{|c|}{ Performed on } & \multirow{2}{*}{$\begin{array}{c}\text { Analytical } \\
\text { Quantification } \\
\text { Limits } \\
\end{array}$} \\
\hline & & Solid & Liquid & \\
\hline $\begin{array}{l}\text { Gross characterization/ } \\
\text { description }\end{array}$ & 8.1 & $\begin{array}{l}\mathbf{Y} \\
\mathbf{Y}\end{array}$ & $\begin{array}{l}Y \\
Y\end{array}$ & \\
\hline $\begin{array}{l}\text { Water content } \\
\text { pH }\end{array}$ & & $\mathbf{Y}$ & $\mathbf{Y}$ & \\
\hline $\begin{array}{l}\text { TCLP } \\
\mathrm{As} \\
\mathrm{Ba} \\
\mathrm{Cd} \\
\mathrm{Cr} \\
\mathrm{Pb} \\
\mathrm{Hg} \\
\mathrm{Se} \\
\mathrm{Ag}\end{array}$ & 8.2 & $\begin{array}{l}\mathbf{Y} \\
\mathbf{Y} \\
\mathbf{Y} \\
\mathbf{Y} \\
\mathbf{Y} \\
\mathbf{Y} \\
\mathbf{Y} \\
\mathbf{Y}\end{array}$ & $\begin{array}{l}\mathrm{Y} \\
\mathrm{Y} \\
\mathrm{Y} \\
\mathrm{Y} \\
\mathrm{Y} \\
\mathrm{Y} \\
\mathrm{Y} \\
\mathrm{Y}\end{array}$ & $\begin{array}{rl}5 . & \mathrm{ppm} \\
100 . & \mathrm{ppm} \\
1 . & \mathrm{ppm} \\
5 . & \mathrm{ppm} \\
5 . & \mathrm{ppm} \\
0.2 & \mathrm{ppm} \\
1 . & \mathrm{ppm} \\
5 . & \mathrm{ppm}\end{array}$ \\
\hline $\begin{array}{l}\text { ICP } \\
\text { (Ag, Al, As, B, Ba, Be, Ca, Cd, } \\
\text { Co, Cr, Cu, Fe, K, Li, Mg, } \\
\text { Mn, Mo, Na, Ni, P, Pb, Sb, } \\
\text { Se, Si, Sn, Sr, Ti, V, Zn, Zr) }\end{array}$ & 8.3 & $\mathbf{Y}$ & $\mathbf{Y}$ & \\
\hline $\begin{array}{l}\text { Anions/Salts } \\
\text { Chloride } \\
\text { Carbonate } \\
\text { Sulfate } \\
\text { Sulfide } \\
\text { Sulfite } \\
\text { Nitrate } \\
\text { Nitrite } \\
\text { Hydroxide } \\
\text { Silicate } \\
\text { Borate } \\
\text { Phosphate } \\
\text { Fluoride }\end{array}$ & 8.4 & $\begin{array}{l}Y \\
Y \\
Y \\
Y \\
Y \\
Y \\
Y \\
Y \\
Y \\
Y \\
Y \\
Y\end{array}$ & $\begin{array}{l}Y \\
Y \\
Y \\
Y \\
Y \\
Y \\
Y \\
Y \\
Y \\
Y \\
Y \\
Y\end{array}$ & $\begin{array}{l}1 \text { wt } \% \\
1 \text { wt } \% \\
1 \text { wt } \% \\
1 \text { wt } \% \\
1 \text { wt } \% \\
1 \text { wt } \% \\
1 \text { wt } \% \\
1 \text { wt } \% \\
1 \text { wt } \% \\
1 \text { wt } \% \\
1 \text { wt } \% \\
1 \text { wt } \%\end{array}$ \\
\hline DOT & 8.5 & $\mathbf{Y}$ & $\mathrm{Y}$ & \\
\hline $\begin{array}{l}{ }^{234} \mathrm{U} \\
{ }^{235} \mathrm{U} \\
\mathrm{U} \text { (Natural) } \\
\mathrm{U} \text { (Depleted) } \\
{ }^{137} \mathrm{Cs} \\
{ }^{230} \mathrm{Th} \\
{ }^{232} \mathrm{Th}\end{array}$ & 8.6 & $\begin{array}{l}Y \\
Y \\
Y \\
Y \\
Y \\
Y \\
Y\end{array}$ & $\begin{array}{l}Y \\
Y \\
Y \\
Y \\
Y \\
Y \\
Y\end{array}$ & $\begin{array}{l}\mathrm{pCi} / \mathrm{g} \\
\mathrm{pCi} / \mathrm{g} \\
\mathrm{pCi} / \mathrm{g} \\
\mathrm{pCi} / \mathrm{g} \\
\mathrm{pCi} / \mathrm{g} \\
\mathrm{pCi} / \mathrm{g} \\
\mathrm{pCi} / \mathrm{g}\end{array}$ \\
\hline TOC & 8.7 & $Y$ & $\mathrm{Y}$ & $50 \mathrm{ppm}$ \\
\hline
\end{tabular}

${ }^{a}$ Or any other analytical method that provides the requested constituents. 


\section{INTRODUCTION}

On June 12, 1992, the U.S. Department of Energy (DOE) Oak Ridge Field Office signed a Federal Facility Compliance Agreement (FFCA) with the U.S. Environmental Protection Agency Region IV (EPA IV) regarding Oak Ridge Reservation (ORR) mixed wastes subject to the land disposal restriction (LDR) provisions of the Resource Conservation and Recovery Act (RCRA). The LDR FFCA (LDR FFCA, 1992) establishes an aggressive schedule for conducting treatability studies and developing treatment methods for those ORR mixed (radioactive and hazardous) wastes listed in Appendix B to the Agreement. These are wastes for which treatment methods and capabilities have yet to be defined. Compliance with Requirement 5 of the Agreement states that

... DOE shall submit to EPA for review and approval a plan for the treatment of the LDR prohibited wastes identified in Appendices 1B, 2B, and 3B. This plan must identify the treatment strategy for such wastes to meet LDR treatment standards and must include a schedule, not to exceed two (2) years after the submittal of this plan (i.e., March 1995), for the evaluation and prioritization of treatment method options, treatability studies if required, and technology development.

At a higher level, this requirement was satisfied by the DOE strategic plan for Appendix B wastes (U.S. DOE, 1993). In the strategic plan, the wastes are divided into two categories:

1. those wastes, listed in Appendices 1A, 2A, and 3A of the Agreement, for which treatment methods and facilities exist that meet the LDR standards; and

2. those wastes, listed in Appendices 1B, 2B, and 3B of the Agreement, for which no treatment methods or facilities exist that meet the LDR standards (hereafter referred to as Appendix B wastes).

A development, demonstration, testing, and evaluation (DDT\&E) program has been initiated to provide those efforts necessary to identify treatment methods for all of the wastes that meet Appendix B criteria. The DDT\&E program has assembled project teams to address treatment development needs in a variety of areas, including that of final waste 
forms (i.e., stabilization/solidification processes). As more definitive characterization data on the waste are obtained, any wastes newly classified as Appendix B wastes will be so identified in updates to the FFCA and will be included in treatment development programs.

In the context of this report, solidification refers to treatment that renders the waste a "solid." Solidification encompasses technologies such as filtration, drying, and calcination that remove liquid and result in a dry or "solid" residue. Coating the dry waste with a polymer or similar substance would be considered solidification within the context of this project. Stabilization, which may also involve solidification, refers to treatment which reacts with the waste constituents of concern to render them nonhazardous or convert them to a chemical form which is less hazardous. As most processes involving stabilization also involve solidification, they are referred to as stabilization/solidification (S/S) processes. The Final Waste Form Project will give priority to the more traditional S/S processes, but it will not exclude such technologies as filtration and drying. Waste-form types being actively considered by this project include grout (e.g., cement-based technology), glass (e.g., vitrification technology), and organic binders (e.g., polymer encapsulation). It is not clear, at preseni, what the final form and composition of the yet-to-be-determined treatment method residues will be and which waste streams will require, or are candidates for, S/S. In addition, ongoing waste characterization has not progressed to the point where potential waste candidates for $S / S$ can be readily identified. This process consists of reviewing existing waste records, conducting generator interviews, and performing sampling and analysis, where required, to acquire more detailed information on waste matrices and contaminants. As these data are obtained, candidate waste forms will become more apparent, and regulatory requirements for treatment of specific wastes can be clearly defined.

$\mathrm{S} / \mathrm{S}$ is a common technology used for immobilization of wastes prior to storage or landfilling. The technology has been most commonly studied as a potential technique for immobilization of toxic metal ions or radioactive waste. Complete detoxification of metals by chemical, biological, or other means is impossible; therefore, methods which isolate the hazardous metals or radioelements are necessary. 
The legal driver for S/S originates with RCRA, which does not allow land disposal of many hazardous wastes unless they have been treated to prevent the migration of hazardous constituents into the environment, thus minimizing the short- and long-term threats to human health and environment.

The aim of the present work is to present information collected from a literature search about the mechanisms by which $S / S$ is accomplished and to define the nature of the interferences associated with the presence of various classes of waste components; the . components invesiigated are mainly inorganic, with some references to organics in general. Threshold values at which these interferences are observed, when available, will be provided to inform those involved in waste characterization or treatment of the known concentration where problems may appear and of the potential effect upon the waste-form host.

Conceptually, there are two broad classes of mechanisms involved in the immobilization of waste species in cement-based matrices: namely, physical entrapment and chemical interaction. A major potential concern is that interfering species, such as organic compounds, even in small amounts, can alter S/S processes sufficiently to substantially decrease the ability of the host matrix to immobilize anions, metal, ions, or radioelements, or even to jeopardize the integrity of the cement-based waste form.

It is well known that admixtures can alter the setting characteristics of portland cement. It is not clear whether, and at what concentrations, various waste components that are commonly present in waste streams interfere with the complex setting or chemical fixation reactions, resulting in an altered cement matrix or waste form with poor retention characteristics.

As discussed in this report, the chemistry which takes place during the normal hydration of cement is a complex succession of chemical reactions. Each reaction interacts with the others and leads to the development of hydrates, which are responsible for the compressive strengths of the curing cement paste. 
These reactions are sensitive to their environment, and their normal development can be disrupted by waste species incorporated in their matrix. These waste species may have a particular effect for a given concentration or in a given mixture of waste species; however, for another concentration or in another waste stream, the observed effect might be the opposite. Cement is a "living material" which reacts to its environment under various circumstances. Failure to respect all the requirements for achieving a durable waste form led to a product presenting problems. Two DOE-sponsored workshops illustrate the complexity of cement chemistry when it is applied to waste immobilization (U.S. NRC, 1989; Lomenick, 1990).

This report relies upon the experience of other researchers in the field, as presented in the open literature, as to the level of various waste species that can be considered for $S / S$. A detailed explanation of the synergistic effect of a combination of various waste species on cement-based wastc-form properties is beyond the scope of this report, but we may still point out the successes and failures of others. In this way, we can at least specify the approximate concentration range at which one may be able to solidify wastes, while keeping in mind that no two wastes are ever the same and that only rarely does waste contain a single waste species. 


\section{HYDRATION MECHANISMS OF PORTLAND CEMENT}

The four main constituents of clinker are tricalcium silicate, $\mathrm{C}_{3} \mathrm{~S}$ ( 35 to $65 \%$ ); dicalcium silicate, $C_{2} S$ (10 to $40 \%$ ); tricalcium aluminate, $C_{3} A(0$ to $15 \%)$; and calcium aluminoferrite, $\mathrm{C}_{4} \mathrm{AF}$ ( 5 to $15 \%$ ). In cement chemistry, the following nomenclature is used to designate the various reactive oxides:

- $\mathrm{C}=\mathrm{CaO}$,

- $\mathrm{S}=\mathrm{SiO}_{2}$,

- $\mathrm{A}=\mathrm{Al}_{2} \mathrm{O}_{3}$,

- $\mathrm{H}=\mathrm{H}_{2} \mathrm{O}$, and

- $\mathrm{F}=\mathrm{Fe}_{2} \mathrm{O}_{3}$.

Ordinary portland cement (OPC) is a mixture of clinker and gypsum, this last compound being added as a function of the concentration of calcium aluminate present in the clinker in order to control the rate of set. These four phases have characteristics and specific behaviors which are very different when mixed with water. Even though they all will produce hydration products, the heat generated by each one is different, as well as its rate of reaction with water. $\mathrm{C}_{3} \mathrm{~A}$ releases the maximum amount of heat $(320 \mathrm{cal} / \mathrm{g})$ and is also the first to react with water, followed by $C_{3} S$ and $C_{4} A F(120$ and $100 \mathrm{cal} / \mathrm{g}$ ), the former reacting slightly faster in the presence of water than the latter. The last phase, $C_{2} S$, generates the least amount of heat $(60 \mathrm{cal} / \mathrm{g})$ and is the slowest to react with water (Jones, 1990).

Different authors propose various theories on portland cement hydration. Authors such as Skalny and Young (1980), Regourd (1982), Glasser et al. (1987), Conner (1990), Lea (1971), and Taylor (1990) are among the most frequently cited sources on the topic.

As long ago as the end of the last century, Le Chatellier and Michaelis proposed different theories about the mechanisms of cement hydration. These two chemists agreed on one aspect of their theories, that the aluminate phase was dissolved, and also about the essential importance of $\mathrm{C}_{3} \mathrm{~S}$ in cement hydration. They did not agree on the reactions of 
silica during the hydration of cement. Since then, many other theories, sometimes conflicting, have been proposed by researchers.

Over the last two decades, due to the development and use of sophisticated analytical techniques, some mechanisms have been confirmed; however, much remains to be explained. The very early stages of hydration remain a particularly controversial topic among many scientists today. Most agree on the hydration mechanism for $\mathrm{C}_{3} \mathrm{~A}$, which follows a dissolution-crystallization process; however, scientists cannot reach a consensus on the mechanism surrounding $\mathrm{C}_{3} \mathrm{~S}$ hydration.

Even though a large number of theories exist for the hydration of $\mathrm{C}_{3} \mathrm{~S}$, a compromise can be described in the following hydration scheme. The hydration of $\mathrm{C}_{3} \mathrm{~S}$ could be the result of four consecutive steps:

1. During the initial hydrolysis stage, the water hydrolyzes $\mathrm{C}_{3} \mathrm{~S}$ by forming $\mathrm{OH}^{-}$and $\mathrm{Ca}^{2+}$. These ions are leached into solution, and there is a formation of an amorphous silicate surface layer on the external surface of $\mathrm{C}_{3} \mathrm{~S}$ grains.

2. In the second stage, the previous reactions continue their development by increasing the size of the amorphous silicate layer and the concentration of $\mathrm{Ca}^{2+}$ and $\mathrm{OH}^{-}$ present in solution. The kinetics, however, are reduced because of the electrical double layer that the ions must pass through. Nuclei of hydrated calcium silicates (CSH) and portlandite $(\mathrm{CH})$ are formed but cannot grow yet into crystals.

3. The third stage occurs when the solution becomes supersaturated with respect to calcium hydroxide, resulting in a rapid growth of crystals of $\mathrm{CH}$ and a development of CSH. These CSH "pseudocrystals" will be located at first close to the $\mathrm{C}_{3} \mathrm{~S}$ boundary, where the solution is the richest in the necessary silicate ions for crystal formation. Calcium hydroxide crystals can be found further from the surface, and their formation is controlled by the supersaturation of the solution. The reaction then becomes diffusion controlled. The calcium hydroxide crystallizes into hexagonal plates, while CSH is usually poorly crystallized. 
4. The rapid crystal growth of the previous stage slows down while the supersaturated solution concentration decreases. At this stage, the growth takes place in the contours of the grain, "inner CSH," and the size of the anhydrous part is reduced. The microstructure and composition of the inner and outer CSH can be very different as a result.

The literature usually indicates an "amorphous" nature of the CSH; however, these hydrates exhibit a short-range ordering even if they are considered $\mathrm{X}$-ray amorphous because the long-range ordering is minimal (Walton, 1990). When observed with a scanning electron microscope (SEM), some typical patterns for the CSH can be found; Taylor (1990) describes these patterns. On an X-ray spectrum of a fully hydrated OPC, one can observe very few and wide peaks corresponding to the diffraction of CSH. Taylor (1986) describes the CSH as a "gel structured at the nanometre level."

The hydration of $\mathrm{C}_{2} \mathrm{~S}$ has been studied less than the hydration of $\mathrm{C}_{3} \mathrm{~S}$, mainly due to its lesser abundance in clinker compared with $\mathrm{C}_{3} \mathrm{~S}$ and also because of its slow hydration kinetics in the total hydration mechanism. Researchers who studied this compound have concluded their work by saying that there are no major differences in the hydration mechanisms of the two silicates.

The theory for $\mathrm{C}_{3} \mathrm{~A}$ hydration that appears to be quoted most often by many researchers is that $\mathrm{C}_{3} \mathrm{~A}$ hydration is due to the growth of hexagonal-shaped crystals $\left(\mathrm{C}_{4} \mathrm{AH}_{13}\right.$ and $\left.\mathrm{C}_{2} \mathrm{AH}_{8}\right)$ around each grain. These crystals, because of the exothermic hydration reaction, will be transformed into $\mathrm{C}_{3} \mathrm{AH}_{6}$ (cubic-shaped crystals), which are stable at higher temperatures. If no sulfate were added to $\mathrm{C}_{3} \mathrm{~A}$, these crystals could provoke a flash set: this is why gypsum is added to act as a retarder by forming a coating of ettringite (needlelike or rodlike crystals with an hexagonal base). As long as gypsum reacts with $C_{3} A$, the retardation effect takes place; when the gypsum is completely consumed, the ettringite can

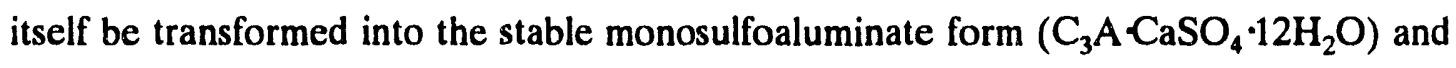
will release sulfate ions into the solution to complete the hydration of the remaining $\mathrm{C}_{3} \mathrm{~A}$. 
The hydration of the last phase involves calcium aluminoferrite and is very similar to that of $\mathrm{C}_{3} \mathrm{~A}$. The kinetics of the reaction, however, is much slower, and the hydration products formed will have a substitution of part of their aluminum by iron, the microstructure being the same.

When cement, which is a mixture of these four phases, is mixed with water, there is nearly an immediate reaction associated with the release of heat. The alkalies present in the various phases will dissolve, and the pore solution will become basic. The fastest-reacting cement phases, $\mathrm{C}_{3} \mathrm{~S}$ and $\mathrm{C}_{3} \mathrm{~A}$, start dissolving incongruently, liberating calcium and hydroxides ions into the pore solution. This solution becomes supersaturated with respect to calcium hydroxide, and this hydroxide will start to precipitate. By using spectroscopy techniques, scientists have been able to determine, within $5 \mathrm{~s}$ after the start of hydration, the superficial composition of hydrating $\mathrm{C}_{3} \mathrm{~S}$. They describe the cement grain surfaces as sites where continual exchanges occur between solid and solution.

During the early period, that is, up to $3 \mathrm{~h}$ into the reaction, tricalcium aluminate, $C_{3} A$, will react very fast with the sulfate from gypsum to form gelatinous ettringite. These amorphous gel deposits will surround the cement grains, forming a layer which will partially prevent water from gaining access to grains for further hydration. This decrease in the rate of hydration is called the dormant phase. In this phase, the reaction is continuing, but very slowly compared with the faster reactions involved at the start of the hydration reaction. The length of this phase is about 0.5 to $2 \mathrm{~h}$.

The middle period of the hydration lasts 3 to $20 \mathrm{~h}$. At the beginning of this period, the unstable protective film formed around the cement grains will be ruptured after a few hours, allowing the mechanisms of hydration to resume at a normal rate. This end of the dormant phase, corresponding to the rupture of the semipermeable layer surrounding $\mathrm{C}_{3} \mathrm{~S}$ grains, can be explained by the action of osmotic pressure (theory of Double) or the crystallization of $\mathrm{Ca}(\mathrm{OH})_{2}$ on its surface (theory of Jennings). Both theories, however, come to the same conclusion: the silica-rich solution inside the membrane can react with the $\mathrm{Ca}^{2+}$ in the external solution, forming $\mathrm{CSH}$ and $\mathrm{CH}$, also called portlandite. The rate of formation of these crystals is accelerated after the dormant phase. 
During this middle phase, setting and hardening will occur. The hydration is progressing, and $\mathrm{CSH}$ are now found in the shells of anhydrous $\mathrm{C}_{3} \mathrm{~S}$ grains. The space between the grains is filled with the various hydrates, replacing the initial solution. The imbricate structure of the various hydrates will cause hardening and the development of mechanical strength. The late period sees only a continuation of these reactions, and after 1 month, an ordinary portland cement reaches about $90 \%$ of its final strength.

Water is a constituent of all the hydrates formed during the hydration process. The amount of water to add to cement in order to obtain a neat paste is a function of the properties of the cement itself (e.g., finesse, composition, temperature) and for an OPC is usually slightly less than $30 \mathrm{wt} \%$ of the cement weight. If a cement is mixed with insufficient water, it will develop less mechanical strength than if the correct amount of water is used. The integrity of a waste form created with insufficient water could be jeopardized. The primary non-balanced reactions, showing only the reactants and products, which are known to occur during the cement hydration and the principal hydrates that are formed when cement comes in contact with water are as follows:

$\mathrm{C}_{3} \mathrm{~S}, \mathrm{C}_{2} \mathrm{~S}$

$\mathrm{C}_{3} \mathrm{~A}$

$\mathrm{C}_{3} \mathrm{~A}+$ gypsum $\rightarrow \quad \mathrm{C}-\mathrm{S}-\mathrm{H}$ and $\mathrm{Ca}(\mathrm{OH})_{2}$

A fully hydrated cement paste contains a volume of about 50 to $60 \% \mathrm{CSH}$ and 20 to $25 \%$ $\mathrm{Ca}(\mathrm{OH})_{2}$.

$\rightarrow \mathrm{C}_{2} \mathrm{AH}_{8}+\mathrm{C}_{4} \mathrm{AH}_{13}+\mathrm{C}_{3} \mathrm{AH}_{6}$

$\rightarrow \quad \mathrm{C}_{3} \mathrm{~A} \cdot 3 \mathrm{CaSO}_{4} \cdot 32 \mathrm{H}_{2} \mathrm{O}$ ettringite $\mathrm{C}_{3} \mathrm{~A} \cdot \mathrm{CaSO}_{4} \cdot 12 \mathrm{H}_{2} \mathrm{O}$ calcium monosulfoaluminate $\mathrm{C}_{4} \mathrm{AH}_{13}$ calcium aluminates

Calcium sulfoaluminates represent 15 to $20 \%$ of the fully hydrated cement paste volume.

$\mathrm{C}_{4} \mathrm{AF}$

- $\mathrm{C}_{2}(\mathrm{~A}, \mathrm{~F}) \mathrm{H}_{8}+\mathrm{C}_{4}(\mathrm{~A}, \mathrm{~F}) \mathrm{H}_{13}+\mathrm{C}_{3}(\mathrm{~A}, \mathrm{~F}) \mathrm{H}_{6}$ 


$$
\begin{array}{ll}
\mathrm{C}_{4} \mathrm{AF}+\text { gypsum } \rightarrow \quad & \mathrm{C}_{3}(\mathrm{~A}, \mathrm{~F}) \cdot 3 \mathrm{CaSO}_{4} \cdot 32 \mathrm{H}_{2} \mathrm{O} \\
& \mathrm{C}_{3}(\mathrm{~A}, \mathrm{~F}) \cdot \mathrm{CaSO}_{4} \cdot 12 \mathrm{H}_{2} \mathrm{O} \\
& \mathrm{C}_{4}(\mathrm{~A}, \mathrm{~F}) \mathrm{H}_{13}
\end{array}
$$

Chemical fixation of mixed wastes can be achieved by using of OPC because of substitution/incorporation of some species in the hydrated crystalline phases. Glasser (1992) reports that some of these species can be incorporated by the following:

1. substitution for calcium: $\mathrm{Sr}^{2+}, \mathrm{Ba}^{2+}, \mathrm{Pb}^{2+}$;

2. substitution for hydroxyl: $\mathrm{F}^{-}, \mathrm{Cl}^{-}, \mathrm{Br}^{-}, \mathrm{I}^{-}$;

3. substitution for $\mathrm{SO}_{4}$ in ettringite and monosulfoaluminate: $\mathrm{IO}_{3}{ }^{-}, \mathrm{CrO}_{4}{ }^{2-}, \mathrm{SeO}_{4}{ }^{2-}$; or

4. substitution for $\mathrm{Al}, \mathrm{Fe}: \mathrm{M}^{3+}, \mathrm{Cr}^{3+}$.

Although the number of reactions involved in the hydration of OPC is complex for the neat cement, neat cement is rarely, if ever, used alone. When used as a binder to produce waste forms, OPC might be blended with additives that will modify some properties of the final product. Some of the additives used for this purpose and the effect that they may have can be generally summarized as follows:

- Fly ash: Decreases permeability, increases mix fluidity, and lowers initial heat evolution. When added to an OPC, a pozzolanic fly ash will generate CSH, which is more amorphous, contains more aluminum, and has a Ca:Si ratio lower than OPC CSH (Regourd, 1987).

- Blast furnace slag: Decreases permeability, lowers internal solution redox potential (Eh), lowers initial heat evolution, increases mix fluidity, and helps with the retention of mobile species, especially reducible species. Blast furnace slag (BFS) is also a hydraulic material that is activated in cement by the portlandite $(\mathrm{CH})$ released by the clinker, producing hydrated compounds such as $\mathrm{CSH}$ with 
low Ca:Si ratios and sulfoaluminates (Glasser et al., 1987; Regourd, 1987; Daimon, 1980).

- Natural pozzolans, clays: Increase sorption of certain cations. No hydration products are generated by clays in the presence of OPC.

- Silica fume: Decreases permeability and increases sorption of metals and nonmetals. Its hydration in an OPC blend will produce type III CSH with a very low Ca:Si ratio (Glasser, 1992; Regourd, 1987).

- Sodium silicate: Precipitates heavy metals, decreases permeability, increases strength, and hastens the set in the presence of pozzolans, ashes and fumes. It produces $\mathrm{CSH}$ by capturing the calcium ions released by the hydrolysis of cement.

- Calcium hydroxide, sodium hydroxide: Condition borate and sulfate waste as well as other waste species which can be precipitated to form insoluble or inoffensive compounds better suited for the final waste form and hasten set in the presence of pozzolans, ashes, and fumes.

\begin{abstract}
Although the single effect of any one of the common additives in the preceding list can be stated in general terms, specific reactions between more than one additive or reactions with OPC or waste solution are far too complex to contemplate. It is for this reason that waste-form development and its associated science must rely so heavily upon an empirical approach to this developing field.
\end{abstract}




\section{MECHANISMS OF RETARDATION AND ACCELERATION OF CEMENT SET- FACTORS AFFECTING THE DURABILITY OF WASTE FORMS}

The hydration mechanisms of cement pastes are complex series of chemical reactions, dissolutions, precipitations, exchanges, and crystallizations which can be disturbed in many different ways. The most common disturbance resulting from the presence of altering waste species results in inhibiting or accelerating the expected rate of some phase of the process.

Many mixed wastes very often contain "troublesome" species, presenting problems for the set of cement or the durability of the final waste form. In the following sections, descriptions of such troublesome species will be made, and threshold values at which interferences can be obtained will be presented, when available. It should be understood that the effects of each are also a function of the particular type of waste stream and other components. Lea (1971) discusses the effect of various salts on the setting of cement and states: "The available data are often conflicting and the effect produced often varies with the composition of the portland cement used."

In a review of cement-based immobilization at DOE sites, Dole (1985) discusses the complexity of dealing with mixtures of many waste species. He also presents the ranking of common anions and cations which can be accelerators or retarders of the set of portland cement, as follows :

\section{Cations:}

$$
\begin{aligned}
& \mathrm{Ca}^{2+}>\mathrm{Ni}^{2+}>\mathrm{Ba}^{2+}, \mathrm{Mg}^{2+}>\mathrm{Fe}^{3+}>\mathrm{Cr}^{3+}>\mathrm{Co}^{2+}>\mathrm{La}^{3+}>\mathrm{NH}^{4+}, \mathrm{K}^{+}>\mathrm{Li}^{+}>\mathrm{Cs}^{+}>\mathrm{Na}^{+} \\
& <----------A c c e l e r a t i o n \mid
\end{aligned}
$$

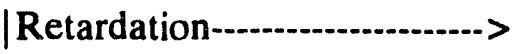

$$
\begin{aligned}
& \mathrm{Cu}^{2+}>\mathrm{Zn}^{2+}>\mathrm{Pb}^{2+}
\end{aligned}
$$


Anions:

$$
\begin{aligned}
\mathrm{OH}^{-}>\mathrm{Cl}^{-}>\mathrm{Br}^{-}>\mathrm{NO}_{3}^{-}>\mathrm{SO}_{4}^{2-}>>\mathrm{CH}_{3} \mathrm{CO}_{2}^{-} \\
<<- \text {Acceleration } \mid
\end{aligned}
$$

This type of ranking must be considered as only a general guide, and caution must be exercised when using it. Because a cation is never found alone but is associated with at least a single anion, the presence of the anion will also contribute to the total effect of the waste salt on cement properties. As an example, Regourd (1982) ranked the common chloride salts and noticed that the accelerating effect, when considering $\mathrm{C}_{3} \mathrm{~S}$ hydration, was more pronounced for $\mathrm{MgCl}_{2}$ than for $\mathrm{CaCl}_{2}$. Also, it is observed that the concentration at which the salt is added can modify the observed effect on the set of the cement.

The previous section states that $C_{3} S$ and $C_{3} A$ are the two main phases responsible for the beginning of hydration in cement. Under normal circumstances, $\mathrm{C}_{3} \mathrm{~A}$ is responsible for abnormalities and the rate at which the set is achieved, while $\mathrm{C}_{3} \mathrm{~S}$ hydration affects the final set of cement. These two phases are not sensitive to the same compounds, and, in the case of a mixed waste incorporated into a cement matrix, the final result upon the set will be a compromise of various effects.

\subsection{ACCELERATING ADMIXTURES}

\subsubsection{Admixtures Accelerating $\mathrm{C}_{3} \mathrm{~S}$ Hydration}

The role of an accelerator is to promote the dissolution of the calcium cations and anions from cement, thus promoting the formation of $\mathrm{CSH}$ and $\mathrm{CH}$ nuclei (Taylor, 1990). The mechanisms inducing this accelerating reaction are not known, and little research has been performed on this topic. However, most inorganic electrolytes, especially soluble calcium salts, are found to be accelerators for $\mathrm{C}_{3} \mathrm{~S}$.

Among them, calcium chloride is the most widely used and studied. Aqueous solutions of various chlorides are commercially found in accelerating admixtures such as $\mathrm{Ca}, \mathrm{Al}$, and $\mathrm{Na}$, as well as in aqueous solutions of alkali carbonates, aluminates, and silicates (Lea, 1971). 
Calcium salts usually have an accelerating effect more pronounced than that of potassium salts. On the other hand, sulfate, chromate, and thiosulfate are stronger accelerators than chlorides of calcium or potassium (Regourd, 1982).

Both carbonates, $\mathrm{Na}_{2} \mathrm{CO}_{3}$ and $\mathrm{CaCO}_{3}$, are known to be accelerators as well, even though the mechanism of their action is not understood (Taylor, 1990). Also, calcium aluminates, magnesium oxide, and sodium bicarbonates are listed by Conner (1990) as accelerators that are found in commercial systems. Jones (1990) indicates that sodium fluoride, sodium aluminate, and potassium carbonate are known to be accelerators as well.

\subsubsection{Admixtures Accelerating $\mathrm{C}_{3} \mathrm{~A}$ Hydration}

Very few studies are related to the acceleration effect of $C_{3} A$. However, a few organic compounds are known to be accelerators of $\mathrm{C}_{3} \mathrm{~A}$ hydration, among which triethanolamine is the most we!l known and the most often used commercially. Its effect is comparable to that of sugar, and, when added in large quantities, it will provoke a flash set, even though these compounds are normally retarders with respect to $C_{3} S$ hydration. Skalny and Young (1980) reported that fluoride, which is a retarder for $C_{3} S$ hydration, is recognized as an accelerator for $\mathrm{C}_{3} \mathrm{~A}$.

\subsection{RETARDING ADMIXTURES}

Many waste stream species can produce a retardation of the set when incorporated in cement. Among these, organic compounds such as phenols, glycols, alcohols, carbonyl, carboxylate, chlorinated hydrocarbons, oil, and grease exhibit such an effect. Some inorganic species produce a similar effect: sodium salts of phosphoric, boric, and oxalic acids; some chloride salts; and some heavy metals such as copper or zinc are among the most important (Jones, 1990; Regourd, 1982).

Banfill and Saunders (1986) stated that the mechanisms explaining the retardation effect observed when organic compounds are added to portland cement can possibly be explained by two effects: 
1. The induction period is lengthened due to the sorption of the organic species onto the membranes formed in hydrated cement, and

2. the growth rate of calcium hydroxide crystals is slowed due to the poisoning effect of the sorbed compounds.

Young (1972) studied and reviewed the possible mechanisms that may explain the retarding effect of organic compounds on cement hydration. The conclusion drawn from his analysis was that retardation is probably related to the adsorption of the organics onto calcium hydroxide, thus provoking a retardation of $\mathrm{C}_{3} \mathrm{~S}$ hydration. He also thinks that there is adsorption of organics onto the surface of the hydrated aluminate phases, which could also retard the hydration of $\mathrm{C}_{3} \mathrm{~A}$.

Jennings et al. (1986) studied the effect of organic retarders on pastes of $\mathrm{C}_{3} \mathrm{~S}$-water and of $\mathrm{C}_{3} \mathrm{~A}$-gypsum-water. Their conclusion was that some retarders are incorporated into the hydration products that exist around the $\mathrm{C}_{3} \mathrm{~S}$ grains, slowing the hydration process. The phase change that ends the induction period is, for them, poisoned by the organic compounds present in this layer. For the $\mathrm{C}_{3} \mathrm{~A}$ system, a decrease in the concentration of the organic compounds measured in the surrounding solution showed that part of these organic compounds are adsorbed by the aluminate hydration products.

When comparing the retarding effect of organic compounds, Skalny and Young (1980) concluded that to be a good retarder an organic compound needs a strong chelating group, the best one being $\beta$-hydroxyl-carboxylate.

\subsubsection{Admixtures Retarding $\mathrm{C}_{3} \mathrm{~S}$ Hydration}

Retarding waste species will increase the length of the dormant period of $\mathrm{C}_{3} \mathrm{~S}$ hydration and delay $\mathrm{Ca}(\mathrm{OH})_{2}$ precipitation. The mechanism by which this effect occurs is, according to many authors, related to the formation of a coating of insoluble, amorphous gels around the $\mathrm{C}_{3} \mathrm{~S}$ grains, preventing access to the solution. This phenomenon is observed in the presence of fluorides and phosphate salts (Skalny and Young, 1980), as well as in organic compounds such as lignosulfonates, sodium gluconate, sugar, and many other 
organic acids. The magnitude of the delay is usually a function of the concentration of the admixture used.

\subsubsection{Admixtures Retarding $\mathrm{C}_{3} \mathbf{A}$ Hydration}

The retardation effect can also result from interferences with the development of $\mathrm{C}_{3} \mathrm{~A}$ hydration. The presence of sodium and potassium ions in the internal pore solution will produce a very basic environment and will function as a retarder for $\mathrm{C}_{3} \mathrm{~A}$ because of the formation of an amorphous precipitate of $\mathrm{Ca}(\mathrm{OH})_{2}$.

Chromate, sulfate, and carbonate salts can also moderate the set of cement. Chromate salts act similarly to sulfate by forming chromoaluminate crystals $\left(\mathrm{C}_{3} \mathrm{ACaCrO} \mathrm{CrH}_{2} \mathrm{O}\right)$ that can cover $\mathrm{C}_{3} \mathrm{~A}$ grains (Regourd, 1982). As already discussed, gypsum is added to clinker to regulate the rate of hydration. When calcium chloride salt is added, the moderating effect of gypsum is affected, and an acceleration of the set is observed instead, along with the formation of calcium chloroaluminates, $\mathrm{C}_{3} \mathrm{~A} \cdot \mathrm{CaCl}_{2} \cdot 10 \mathrm{H}_{2} \mathrm{O}$.

In a carbonated pore solution (containing $\mathrm{Na}_{2} \mathrm{CO}_{3}$ or $\mathrm{CaCO}_{3}$ ) the formation of ettringite will decrease, and new crystals of thaumasite $\left(\mathrm{CaCO}_{3} \mathrm{CaSO}_{4} \cdot \mathrm{CaSiO}_{5} \cdot 15 \mathrm{H}_{2} \mathrm{O}\right)$ will be observed instead. This decrease in the amount of ettringite, a set regulator, will result in an accelerating effect upon the cement.

The most well known species for retardation of $\mathrm{C}_{3} \mathrm{~A}$ reactivity is sucrose (sugar), which forms complexes with $\mathrm{C}_{3} \mathrm{~A}$ and aluminate phases, acting as a piotective layer. Added as a solution of $1 \%$ sugar, this species almost completely inhibits the setting and hardening of cement paste.

\subsection{DURABILTY OF WASTE FORMS}

The risk of attack by external species during storage of waste forms will not be examined because this subject is too broad and is very specific to the local environment of the storage area. However, some of the species found in mixed wastes that are immobilized in 
cement-based waste forms can compromise the integrity of the waste form during storage. In order to maintain its containment properties, a package must maintain its integrity: that is, have no cracking, spalling, or other physical damage (Glasser, 1992). This is also a requirement of both DOE and the U.S. Nuclear Regulatory Commission (NRC).

The greatest risk for such damage comes from the formation of expansive compounds formed by reaction between the waste and the cement itself. Other kinds of adverse physical reactions originate from thermal stresses resulting from excessive heat produced during hydration, thermal cycling, settlement, internal shrinkage, and waste reactions producing gas pressure. Tailoring a correct formulation containing the right additives can prevent some of these problems.

In the context of this report, we concentrate our attention on the chemical interactions that can take place in a solidified waste form during storage and compromise its ability to contain the hazardous and radioactive species.

Some authors discuss the role of organics not only as being a problem for the set of cement but also as presenting a danger for the durability of the waste form. Toste (1984) indicated that ethylene glycol, as well as some organic acids (acetic, butyric, formic, and lactic), can promote a slow disintegration of concrete, while stearic acid will promote a rapid disintegration. Glasser (1992) mentioned citrate, oxalate, ethylene diaminetetraacetic (EDTA), and sugar as being able to produce degradation products.

Cracking and spalling can occur as a result of the formation of expansive ettringite in a waste form containing a sulfate-rich waste which has not been pretreated in order to reduce the mobility and availability of the sulfate ions and the formation of more insoluble sulfate compounds. The transformation of monosulfoaluminate into ettringite is accompanied by a $77 \%$ volume increase (Roy, 1986). Many wastes, if not pretreated, can present problems for the waste-form integrity: not only sulfate compounds but also acid compounds and, to a lesser extent, chloride and magnesium compounds. Roy (1986) reported that sodium and potassium chloride, if concentrated in solution, can cause disintegration of concrete. 


\section{REGULATORY LIMIS AS THEY APPLY TO MIXED WASTES}

The dual nature of mixed wastes, hazardous and radioactive, means that they must comply with three types of regulations (four types if they are shipped off-site over public roads). These regulations include those of EPA, NRC, DOE and the U.S. Department of Transportation (DOT).

In our literature review, we found threshold values for some waste species indicating at what concentration they could present a problem for cement-based waste forms. The problems encountered were related to the set of the cement, the durability of the waste forms, and the ability of the waste forms to confine the hazardous or radioactive species inside of the matrix.

If a waste stream does not contain species that could alter the set of the cement binder or the durability of the resulting waste form, then the leaching properties become the only concern for this particular waste form. In this case the limits found in the regulations become the detection limit that needs to be considered as a conservative sensitivity level. Both the constituent of interest and the acceptable concentration limit specified in the regulations are waste specific.

Mattus et al. (1988) wrote a review and synopsis of the different regulations which apply to mixed wastes, that is, toxicity characteristic contaminants (RCRA waste), National Primary Drinking Water Standards, National Secondary Drinking Water Standards, NRC requirements, and DOE regulations. Gilliam et al, (in press) wrote an update of the regulatory review, which includes the LDR of RCRA. A comparison of the two documents clearly points out the changing nature of the regulations. The reader is cautioned that references to regulatory required concentration limits reflect values current at the time that the document was prepared and that the regulations are subject to change.

A synopsis of the regulations is beyond the scope of this report, and the reader is referred to the two summary documents for additional detail. The listing of waste categories is 
lengthy and will not be presented here. However, the toxicity characteristic contaminants and regulatory levels for RCRA wastes represent a significant portion of the inorganic constituents of concern and are presented in the following table.

\begin{tabular}{|c|c|c|}
\hline $\begin{array}{l}\text { EPA hazardous } \\
\text { waste number }\end{array}$ & Contaminant & $\begin{array}{l}\text { Regulatory level (mg/L) } \\
\text { for the TCLP extract }\end{array}$ \\
\hline$\overline{\mathrm{D} 004}$ & Arsenic & 5.0 \\
\hline D005 & Barium & 100.0 \\
\hline D018 & Benzene & 0.5 \\
\hline D006 & Cadmium & 1.0 \\
\hline D019 & Carbon tetrachloride & 0.5 \\
\hline D020 & Chlordane & 0.03 \\
\hline D021 & Chlorobenzene & 100.0 \\
\hline D022 & Chloroform & 6.0 \\
\hline D007 & Chromium & 5.0 \\
\hline D023 & 0 -Cresol & 200.0 \\
\hline D024 & $m$-Cresol & 200.0 \\
\hline D025 & $p$-Cresol & 200.0 \\
\hline D026 & Cresol & 200.0 \\
\hline D016 & 2,4-D & 10.0 \\
\hline D027 & 1,4-Dichlorobenzene & 7.5 \\
\hline D028 & 1,2-Dichloroethane & 0.5 \\
\hline D029 & 1,1-Dichloroethylene & 0.7 \\
\hline D030 & 2,4-Dinitrotoluene & 0.13 \\
\hline D012 & Endrin & 0.02 \\
\hline D031 & Heptachlor & 0.008 \\
\hline D032 & Hexachlorobenzene & 0.13 \\
\hline D033 & Hexacloro-1,3-butadiene & 0.5 \\
\hline D034 & Hexachloroethane & 3.0 \\
\hline D008 & Lead & 5.0 \\
\hline D013 & Lindane & 0.4 \\
\hline D009 & Mercury & 0.2 \\
\hline D014 & Methoxychlor & 10.0 \\
\hline D035 & Methyl ethyl ketone & 200.0 \\
\hline D036 & Nitrobenzene & 2.0 \\
\hline D037 & Penthachlorophenol & 100.0 \\
\hline D038 & Pyridine & 5.0 \\
\hline D010 & Selenium & 1.0 \\
\hline D011 & Silver & 5.0 \\
\hline D039 & Tetrachloroethylene & 0.7 \\
\hline D015 & Toxaphene & 0.5 \\
\hline D040 & Trichloroethylene & 0.5 \\
\hline D041 & 2,4,5-Trichlorophenol & 400.0 \\
\hline D042 & 2,4,6-Trichlorophenol & 2.0 \\
\hline D017 & $2,4,5-\mathrm{TP}$ & 1.0 \\
\hline D043 & Vinyl chloride & 0.2 \\
\hline
\end{tabular}

Source: 55 FR 11804 and 11815-11816 
If the TCLP extract of a waste stream contains concentrations for the preceding species below the regulatory level, the waste will not be considered as a RCRA waste. It will still have to comply with other regulations for its disposal, such as NRC or DOE requirements, LDR requirements and the EPA Safe Drinking Water Act.

This last regulation, the Safe Drinking Water Act, addresses the National Primary Drinking Water Standards and the National Secondary Drinking Water Standards. The primary standards, which are federal, are limits for public water systems and for hazardous waste sites. The secondary standards are not so stringent. The limits for these two standards are presented in the following tables:

National Primary Drinking Water Standards (values are in milligrams per liter unless otherwise indicated)

Contaminant Maximum concentration or level

Arsenic

0.05

Barium

1.00

Cadmium

0.01

Chromium

0.05

Fluoride

4.00

Lead

0.05

Mercury

0.002

Nitrate (as N)

10.0

Selenium

0.01

Silver

0.05

Endrin

Methoxychlor

0.0002

Toxaphene

0.1

2,4-D

0.005

2,4,5-TP Silvex

0.1

Radium

0.01

Gross alpha

$5 \mathrm{pCi} / \mathrm{L}$

Gross beta

$15 \mathrm{pCi} / \mathrm{L}$

Turbidity

Coliform bacteria

$4 \mathrm{mrem} /$ year

$1 /$ turbidity unit

$1 / 100 \mathrm{~mL}$

Source: 40 CFR 141.11-14 
21

National Secondary Drinking Water Standards

Contaminant

Maximum concentration (mg/L)

Chloride

Copper

Fluoride

250.0

Foaming agents

1.0

2.0

Iron

0.5

Manganese

Sulfate

0.3

Zinc

0.05

250.0

Source: 40 CFR 143.3 


\section{REVIEW OF INORGANIC SPECIES THAT INTERFERE WITH THE DEVELOPMENT OF CEMENT-BASED WASTE FORMS}

Many papers on the general topic of the influence of inorganic species that can interfere with the S/S process were found and reviewed: (U.S. EPA, 1989; Jones, 1990; Glasser, 1992; Conner, 1990; Metcalf \& Eddy Inc., 1991). Many authors make general observations about the observed effect of some of these species, and very few limits are presented regarding the maximum loading that does not cause problems for the final waste form. Many authors state that more studies need to be performed on the topic of interference.

Too little is known about the interference mechanisms which occur when a complex waste containing various inorganics is added even to neat portland cement. Most waste streams are mixtures of many species that can include inorganics, organics, and/or radioelements. When considering such complex wastes, all theoretical knowledge is of limited value, and tests need to be performed in order to examine the properties of the waste and its effect upon the host waste form.

Conner (1992) reviewed organic and inorganic species known to interfere with portland cement and the way these interferences are manifested in the final waste form: for example, effects on set time, durability, expansive degradation, or changes in porosity.

\subsection{ANIONIC SPECIES}

\subsubsection{Chloride}

The effect of chloride on the set of cement varies, depending upon the nature of the cation it is associated with and the concentration of the salt. Lea (1971) presents the following data on the influence of this anion, which is common to many wastes:

1. Calcium chloride: This salt has a dual effect upon the set because at concentrations less than $1 \%$ (based upon the weight of cement), the action of $\mathrm{CaCl}_{2}$ is to retard the set of OPC, while the addition of larger amounts produces an acceleration. In some 
cases, the addition of $3 \%$ can cause a flash set. The intended addition of $\mathrm{CaCl}_{2}$ as set accelerator usually requires up to $2 \%$, based upon the weight of cement (Troxell et al., 1968). Vidick et al. (1989) attributed this acceleration phenomenon to the ability of $\mathrm{CaCl}_{2}$ to shorten the time necessary to achieve supersaturation with respect to portlandite.

2. Sodium chloride: This salt produces erratic effects: it accelerates the set of some portland cements and retards others. Taylor (1990) discusses its use as an accelerator over a concentration range of 2 to $3.5 \%$ sodium chloride based upon the weight of cement.

3. Aluminum and magnesium chloride: These salts have a considerable accelerating effect upon the set of cement.

4. Alkali chlorides: The effect of alkali chlorides upon the hydration of cement is reported to be variable and otherwise minimal.

5. Barium and strontium chloride: These salts have only a slight accelerating effect upon the set of cement.

6. Ammonium, iron, and cobalt chloride: These salts retard set if their concentration is below $2 \%$, while they can accelerate it if the concentration exceeds $2 \%$, based upon the weight of cement.

Regourd (1982) states that the observed accelerating effect of chloride is related to the mobility of the chloride ion. The diffusion coefficient of chloride decreases in order from $\mathrm{MgCl}_{2}$ to $\mathrm{NaCl}$ :

$$
\mathrm{MgCl}_{2}>\mathrm{CaCl}_{2}>\mathrm{LiCl}>\mathrm{KCl}>\mathrm{NaCl} \text {. }
$$

The accelerating effect of chloride upon $\mathrm{C}_{3} \mathrm{~S}$ follows the same order.

In general, as the preceding sequence shows, calcium salts accelerate the set more than potassium salts. Anions such as sulfate, chromate, or thiosulfate accelerate the set even more than chloride. This is the case for calcium as well as potassium.

Brown et al. (1985) studied the effect of inorganic salts on tricalcium silicate hydration. They found that calcium chloride was the strongest accelerator among the species they 
investigated. Their conclusion was that there is interdependence of different factors in influencing the rate of $\mathrm{C}_{3} \mathrm{~S}$ hydration: the depression of the solution $\mathrm{pH}$, colloid flocculation, and microstructural development.

The influence of different types of saline waters upon the set of portland cement was studied by Ghorab et al. (1990), who showed that set time is not significantly modified when considering the amount of dissolved salts in water. Seawater containing $31 \mathrm{~g} / \mathrm{L}$ chloride and $2.5 \mathrm{~g} / \mathrm{L}$ sulfate had an initial set timt of $114 \mathrm{~min}$ and a final set of $310 \mathrm{~min}$. With the same formulation, but using a groundwatet containing $0.7 \mathrm{~g} / \mathrm{L}$ chloride and $0.9 \mathrm{~g} / \mathrm{L}$ sulfate, the initial set time was $108 \mathrm{~min}$, and the final, $374 \mathrm{~min}$. In the case of the groundwater, the authors believe that other species (for which no analyses were made) may have influenced the set time, thus yielding results that do not follow the concentration trend of chloride and sulfate.

Interestingly, even very mobile chloride ions can be chemically fixed, to a limited degree, by cement in some hydrates. In the CSH network (Taylor, 1990) and in crystals of monochloroaluminates, the following reaction is postulated:

$$
\mathrm{CaCl}_{2}+\mathrm{C}_{3} \mathrm{~A}+10 \mathrm{H}_{2} \mathrm{O} \rightarrow \mathrm{C}_{3} \mathrm{~A} \mathrm{CaCl}_{2} \cdot 10 \mathrm{H}_{2} \mathrm{O}
$$

This monochloroaluminate product is not stable in a sulfate environment, and there will be a transformation leading to the formation of expansive ettringite (Gegout et al., 1992) due to substitution.

As already stated, only a small portion of the chloride present in a waste will be chemically fixed in the hydrates of the cement. The remainder will exist as crystals embedded in the hydrate network. The porosity of the waste form will be the factor determining the leach rate. A low-porosity, high-tortuosity matrix will help aid the retention of these labile ions. Many studies performed on the topic of chloride diffusion favor the hypothesis that a finer microstructure is necessary to reduce the diffusion coefficient of chloride (Malek et al., 1988; Glasser, 1992). 
In the study of Fischer and Johnson (1988), the set time and leachability of highly saltladened wastes were investigated. They studied two matrices: a portland cement-based mixture, and a portland cement plus fly ash mortar mixture. Two mixtures of salts were used: $\mathrm{CaCl}_{2}-\mathrm{NaCl}$ and $\mathrm{KCl}-\mathrm{LiCl}$, with up to $18 \%$ salt inside the mortar matrix. Their conclusions are as follows:

1. In the case of cement paste, a formulation tailored with $2.8 \%$ salt based upon the weight of the waste form had a set time of several hours and leach indices between 7 and 8 for chloride.

2. It was found that up to $18 \mathrm{wt} \%$ salt in the mortar waste form was possible, but the longterm integrity of the waste form can be jeopardized by using more than $18 \%$ salt.

3. The cement plus fly ash mortar matrix exhibited a set time of $4.5 \mathrm{~h}$ using $8 \%$ salt, while the portland cement mortar set time was less than $2.3 \mathrm{~h}$.

4. In general, the leach indices of chloride from the studied mortar mixes were only slightly affected by a salt content up to about $7 \%$ (leach index in the range of 7 to 8 ). Above this level, leach indices decreased.

\subsubsection{Carbonate}

The action of carbonates and bicarbonates (the ratio of which in solution is $\mathrm{pH}$ dependent) upon the set of portland cement was not found to have been studied extensively; therefore, few data are available. Regourd (1982) states that $\mathrm{Na}_{2} \mathrm{CO}_{3}$ and $\mathrm{CaCO}_{3}$ are accelerators for $\mathrm{C}_{3} \mathrm{~S}$ hydration, but the mechanism of their action is not well understood.

Lea (1971) states that the alkali carbonates produce a very strong acceleration of the set and that an addition of 1 to $2 \%$ reduces the initial set time to only a few minutes. Sodium carbonate, when added to a cement with a normal set time, will cause a flash set; added in larger quantities it will not disturb the normal set, and with still increased amounts, a flash set will be obtained again. For potassium carbonate, an addition of $0.25 \%$ to portland cement will result in some retardation of the set, but in larger amounts, the set time decreases, and a flash set is possible. 
The action of the cation, once more, has an important effect, as ammonium carbonate is less active than the alkali carbonates. Lea (1971) states that bicarbonates are found to have a retarding effect upon the set as well.

Carbonate ions present in waste solution can change portlandite $\left[\mathrm{Ca}(\mathrm{OH})_{2}\right]$ into calcite $\left(\mathrm{CaCO}_{3}\right)$ or may be absorbed in the crystalline network of hydrated calcium silicates (CSH), causing them to become amorphous. As a result, there will be an increase in the mechanical strength due to a decrease in the cement paste porosity (Regourd, 1982).

Taylor (1990) also discusses the variable effect of carbonate ions, that, depending on th:? concentration, can accelerate, creating a flash set, or retard the set. He mentions some studies that showed that the retardation at low concentration was due to the formation of a denser protective layer around cement grains. The same layers are likely to be less compact at higher concentrations of carbonate.

\subsubsection{Sulfide, Sulfite, and Sulfate}

\subsubsection{Sulfide and Sulfite}

Of these three forms of sulfur, it is primarily sulfate that is found in soluble form in waste streams. Sulfate stability in solution is sensitive to the presence of alkaline earths such as calcium or magnesium, for they are able to precipitate sulfate, depending upon the waste stream $\mathrm{pH}$. For this reason pretreatment of sulfate-containing solutions is easy to accomplish by way simply adding slaked lime or magnesia.

Sulfide $\left(\mathrm{S}^{2-}\right)$ is not stable in aqueous solution at either low $\mathrm{pH}$ or high $\mathrm{pH}$ : at low $\mathrm{pH}$ it may form hydrogen sulfide, and at high $\mathrm{pH}$ it is easily oxidized to sulfite $\left(\mathrm{SO}_{3}{ }^{2 \cdot}\right)$ or sulfate $\left(\mathrm{SO}_{4}{ }^{2-}\right)$, even by air. In addition, sulfide reacts with many metals, especially heavy metals, to form "highly insoluble" metal sulfides and is therefore used to treat waste streams containing heavy metals. The sulfite anion is the most unstable form and will not exist for very long in a waste stream that has access to the air, for it is quickly oxidized to sulfate. Therefore, of these three possible waste species, it is more probable that only sulfate will be of concern in S/S 
processing, for even sulfide is rarely soluble and tends to precipitate metals or be oxidized to sulfate. The only exception might be photographic waste streams.

If sulfite were present in cement, it would not be stable in the high-pH environment and would be oxidized slowly by oxygen diffusion to sulfate. The same is true for sulfide, which would also eventually be oxidized to sulfate. This conversion to sulfate causes an expansion due to the larger crystal size, and stress can cause cracking or spalling to occur. For this reason, waste streams containing any sulfide or sulfite should be oxidized to sulfate before immobilization.

Depending upon the amount of available aluminum in the waste or in the solid additives, sulfate can also react to form expansive sulfate-based ettringite, again causing waste-form swelling, cracking, or spalling. Other than the problems associated with ettringite formation, already discussed, little information is available in the literature on sulfide and sulfite.

\subsubsection{Sulfate}

Lea (1971) states that sulfate, when added in dilute solution, does not have a very marked effect upon cement properties. Calcium sulfate, however, is used in the cement industry as an additive to the clinker in order to control the rate of set and hydration of the aluminate phase. A synthetic sample of tricalcium aluminate, $C_{3} A$, when placed in water, will produce almost instantaneously a large amount of heat and will become hard in only a few seconds (fast set). These two phenomena, hardening and heat generation, are due to the crystallization of a dense, hydrated calcium aluminate from the supersaturated solution. To control the hydration of $\mathrm{C}_{3} \mathrm{~A}$ in cement, calcium sulfate in the form of gypsum $\left(\mathrm{CaSO}_{4} \cdot 2 \mathrm{H}_{2} \mathrm{O}\right)$ is most commonly used, but it can contain some hemihydrate $\left(\mathrm{CaSO}_{4} \cdot 1 / 2 \mathrm{H}_{2} \mathrm{O}\right)$ or anhydrite $\left(\mathrm{CaSO}_{4}\right)$. The amount added is dependent upon the calcium aluminate content of the cement in order to control the rate of set. This addition of sulfate will lead to the formation of ettringite instead of hydrated calcium aluminates.

Conner (1992), in a review of factors affecting the solidification of cementitious waste forms, states that gypsum is a retarder, while the hemihydrate form is an accelerator for the set. Lea 
(1971) agrees with this observed effect and also states that anhydrite exhibits the same effect that hemihydra te does. He provides the example of the addition of $4 \%$ hemihydrate, which results in an initial set time of about $0.5 \mathrm{~h}$, while the same amount of gypsum will require about $5.5 \mathrm{~h}$ to set.

Calcium sulfate is used more as a "regulator" for the set of cement than as a "retarder." A controlled amount of gypsum is added to clinker during the grinding phase when making cement. The amount of gypsum is closely controlled and regulated, usually to between 1 and $3 \%$ as $\mathrm{SO}_{3}$. An excessive amount of gypsum in cement can cause problems as a result of the formation of expansive sulfate-based ettringite.

Brown et al. (1985), in their study of the effect of inorganic salts on tricalcium silicate hydration, used a saturated solution of calcium sulfate. They observed that the precipitation of portlandite was at first delayed and thus retarded the set but that it was followed by a second phase that accelerated the set when the hydroxyl concentration in the solution decreased.

Although beneficial when used to control the set of cement, calcium sulfate can also be a dangerous waste species, due to its adverse effect upon the durability of the waste form. The transfor $\pi$ ation of calcium sulfate into ettringite can be represented by the following equation:

$$
\mathrm{C}_{3} \mathrm{~A}+3 \mathrm{CaSO}_{4}+32 \mathrm{H}_{2} \mathrm{O} \rightarrow \mathrm{C}_{3} \mathrm{~A} \cdot 3 \mathrm{CaSO}_{4} \cdot 32 \mathrm{H}_{2} \mathrm{O} \text { (ettringite) }
$$

This formation of crystalline ettringite can lead to cracking, swelling, and spalling and thus destroy the final waste form. Ping and Beaudoin (1992) explained this expansion mechanism of sulfate by saying that two conditions are necessary for the expansion: (1) confined crystal growth of ettringite and (2) a value of the solubility product ratio greater than one.

Sulfate ions can present problems for cement-based waste forms, internally or externally. External attack is treated in a number of studies related to the durability of cement paste or concrete in aggressive environments. When present in a waste stream being considered for immobilization in a cement matrix, the greatest risk of attack will be internal. 
Ouyang et al. (1988) describe both kinds of suifate attack. In both cases, the processes lead to the formation of destructive ettringite, but the mechanisms are different for each.

During the internal attack, all the sulfate ions are available to react with $\mathrm{C}_{3} \mathrm{~A}$ as soon as the hydration starts. Gypsum will react with the alkalies of the cement to form portlandite, thus releasing sulfate ions into the cement paste, and leading to the formation of ettringite. When the sulfate ions are exhausted from the internal solution, there is a transformation of ettringite in monosulfoaluminates, which releases more $\mathrm{SO}_{4}{ }^{2 \cdot}$ in the solution, allowing the sulfate ions to react with the excess of anhydrous aluminate phase remaining in the paste. The rate of formation of expansive ettringite in both systems will control the degree and possibility of cracking. If the expansion occurs when the set is not yet complete and the material is still sufficently plastic to accept the deformation, there will be no cracking. If the mechanism occurs after the waste form is hard, the difference in densities between the different crystalline phases will cause cracking to occur. Zhou and Colombo (1984) report a density of $1.73 \mathrm{~g} / \mathrm{cm}^{3}$ for ettringite compared with an average of $2.5 \mathrm{~g} / \mathrm{cm}^{3}$ for the other hydrates. The calcium monosulfoaluminate crystals can also react with the sulfate present in the waste form as the nonhydrated calcium aluminate does, both processes leading to the formation of ettringite.

The conclusion of Zhou and Colombo's study was that cement containing more than $7 \% \mathrm{C}_{3} \mathrm{~A}$ should not be used when there is risk of internal or external sulfate attack. Also, in the case of internal attack, the expansion increases with the amount of cement used in the formulation.

Palmer and Smith (1986) tested the effect of adding increased amounts of sodium sulfate to OPC. The waste that they used was a solution of sulfuric acid that was neutralized and then evaporated to obtain a sodium sulfate salt. They measured an accelerating effect from sodium sulfate on the set time as determined both by conduction calorimetry and by obtaining higher unconfined compressive strengths (UCSs) at only 2 days. They also noticed that this acceleration effect resulted in a very high temperature $\left(120^{\circ} \mathrm{C}\right)$ on a 220 liters-scale test. As a result, they modified their formulation to a $10 \%$ OPC $-90 \%$ BFS blended cement to minimize this effect. They concluded that salt/cement loadings up to $0.12 \%$ are stable 
under normal storage conditions, with BFS reducing the expansion phenomenon produced by sulfate attack.

At the Savannah River Plant, waste containing $1.9 \mathrm{wt} \% \mathrm{Na}_{2} \mathrm{SO}_{4}, 15.6 \mathrm{wt} \% \mathrm{NaNO}_{3}$, and 1.7 wt \% $\mathrm{Na}_{2} \mathrm{CO}_{3}$ was studied. Utilizing this Savannah River salt-based formulation with 38 to $48 \%$ waste solution in the final waste form, Langton et al. (1983) obtained a set time of less than $4 \mathrm{~h}$, which was the requirement for the saltstone waste form. The leach rate of nitrate, which was the must mobile species present in their waste, was used to calculate the release of the other species in the waste. The release was such that the calculated contaminant concentrations were well below drinking water limits in the groundwater at the perimeter of the 100 -acre disposal site.

At West Valley, a waste containing $2.7 \% \mathrm{Na}_{2} \mathrm{SO}_{4}$ in a mixture of salts at $39 \%$ total dissolved solids was studied by McVay et al. (1989). They had to modify their initial laboratory grout formulation using these salts due to the formation of bleed water at the pilot-plant scale. They solved the problem by adding calcium nitrate and sodium silicate to the Type I portland cement used. They also improved the final properties of their product by using these additives. Despite this problem, they were able to successfully immobilize this waste solution containing $2.7 \% \mathrm{Na}_{2} \mathrm{SO}_{4}$.

Evaporator concentrates generated from radioactive wastes produced by nuclear plants can be immobilized in cement-based waste forms. Simulated waste concentrates containing 25 to $50 \%$ sodium sulfate were studied by Zhou and Colombo (1984). They worked with two types of binders: masonry cement and Type I portland cement. They observed that masonry cement could not accer alt loadings greater than $7 \%$ and still maintain its desired properties in an aqueous environment. Incorporation of as much as $\mathbf{4 0 \%}$ salt was possible; however, when the cement was placed in water problems occured. The forms were stressed internally and lost their physical integrity. Under identical conditions, with salt loading up to $9 \%$, Type I Portland cement maintained its integrity.

A surrogate waste containing $225 \mathrm{~g} / \mathrm{L}$ sodium sulfate was studied by laboratories of the European Community. Vejmelka and Sambell (1984) reported that this surrogate was 
immobilized in a cement-based waste form. They did not specify if there were problems related to the set. The $\mathrm{X}$-ray diffraction spectra showed that at 25 days, the initial ettringite formed in the waste form disappeared to form calcium monosulfoaluminate, which is a stable form. They also reported the presence of anhydrous $\mathrm{Na}_{2} \mathrm{SO}_{4}$ salts.

In their study to assess the retention of cesium in cement-based waste forms, De Angelis et al. (1992) studied a boiling-water reactor (BWR) simulated evaporator concentrate containing $21.1 \% \mathrm{Na}_{2} \mathrm{SO}_{4}$ in solution. Radioelement leaching properties of their waste forms were good, despite the very high $\mathrm{Na}_{2} \mathrm{SO}_{4}$ loading content.

\subsubsection{Nitrate and Nitrite}

Nitrates are the most common anions found in many wastes. Nitrites are also sometimes found in waste streams associated with nitrates; however, few literature data were available on this species alone. A large number of publications discuss the solidification of nitrates in cement-based waste forms, usually as part of complex wastes streams. The biggest problem associated with this anion is that it is able to leach rapidly from many waste forms.

Lea (1971) states that nitrates, when added in dilute solution, do not have very marked effects upon cement properties. Nitrate salts are classified as set accelerators by EPA (U.S. EPA, 1989). However, this problem can be overcome, and large amounts of sodium nitrate can be incorporated in cement-based waste forms.

Rebagay and Dodd (1989) worked on two tanks of radioactive waste from the Hanford site. The concentration of nitrate in the actual waste was about $0.002 M$, and the simulated waste used was prepared at $1.5 \mathrm{M}$ nitrate. The major cation species was $\mathrm{Na}^{+}$, present at a concentration of about $0.5 \mathrm{M}$ in the actual waste and $5 \mathrm{M}$ in the simulant. Also present, but in lower quantities, were phosphate, nitrite, and sulfate. Rebagay and Dodd do not discuss problems with set time, and their formulation contained a mixture of Type II portland cement, fly ash, attapulgite clay, and Indian red clay. 
The release of nitrate using the actual waste was not detected (no leach index, below detection limits) due to the low concentrations in the waste. The simulated waste containing $5 M$ nitrate, however, released large amounts of this ion (leach index $=7.4$ ). The authors explain this release by saying that this species does not adsorb on additives such as clay, and does not participate in the cement or fly ash hydration reaction. Their conclusion was that the rate of nitrate release is strongly dependent upon the pore structure of the grout.

A study performed on a simulated evaporator concentrate waste from a French research nuclear center (Bouniol et al., 1988) examined the best admixtures possible to control the release of salt and radioelements. The simulated waste contained $144 \mathrm{~g} / \mathrm{L}$ nitrate, with many other salts present such as phosphate, fluoride, and chloride. The total salt content of the concentrate was $720 \mathrm{~g} / \mathrm{L}$. Additions of $\mathrm{Cs}^{+}, \mathrm{Sr}^{2+}, \mathrm{Co}^{2+}, \mathrm{UO}_{2}{ }^{2+}$ and $\mathrm{Th}_{4}{ }^{+}$salts were made to the simulated waste to represent the radioelements present in the actual waste. Results obtained from many formulations studied gave a range of set times, varying from about 1 to $5 \mathrm{~h}$. The complexity of this waste did not allow any speculation about the net effect of set time before the tests were performed. Leach testing for cesium resulted in leach indices above the NRC requirement of 6 . The conclusion of Bouniol et al.'s study was that salt brine concentrates can be successfully placed in cement-based waste forms by adjusting the formulation and the additives used.

Petersen et al. (1986) introduced $55 \mathrm{wt} \%$ of dry nitrate salt into a cement-based waste form. The formulation used consisted of $18 \mathrm{wt} \%$ Type I portland cement, $55 \mathrm{wt} \%$ spray dryer salt, and $27 \mathrm{wt} \%$ water. This mixture was pourable and became hard in $1 \mathrm{~h}$. Leach testing of the loaded waste forms was not performed, but the authors stated that the leaching performance was not expected to be good. Leaching performance was not of interest, since the final package was to be stored in a dry area.

Tallent et al. (1988) worked on the solidification of the simulated double shell slurry feed (DSSF) from the Hanford site. The composition of the waste was mainly hydroxides ( $\mathrm{NaOH}$ 8.7 $M$ and $\mathrm{KOH} 0.44 M$ ), nitrate [as $\mathrm{Al}\left(\mathrm{NO}_{3}\right)_{3} 1.5 \mathrm{M}$ ], and carbonate $\left(\mathrm{Na}_{2} \mathrm{CO}_{3} 0.3 \mathrm{M}\right)$. Their work did not re'inrt results on set time, but the leaching performance was studied. Most of the furmulations tested had nitrate leach indices above 7. 
Tallent et al. tried different types of admixtures and came to the following conclusions, common to many researchers in the literature:

1. Formulations with ground BFS and containing less fly ash reduce the size of the pores as well as the total porosity, thus improving the leaching performance for labile species such as nitrate. The network of pores is also more tortuous, slowing the diffusion of the nitrate ions.

2. A denser waste form can be achieved by an increase in the cementitious additive content and grout density, which will improve the leaching properties by decreasing the porosity.

3. Diluting the waste had little effect upon the nitrate leach index, which seemed to prove that nitrate was mainly immobilized by physical encapsulation as opposed to chemical reactions with cement hydrates.

Atkins et al. (1991), in their study of the interaction of nitrate with constructional materials, concluded that $\mathrm{NaNO}_{3}$ in massive amounts in OPC does not result in a major change in the $\mathrm{pH}$ of the pore fluid. A large part of the $\mathrm{NaNO}_{3}$ remains soluble and, as a result, can be leached. Atkins stated that the morphology of the cement hydrates is modified and that the presence of $\mathrm{NaNO}_{3}$ appears to enhance calcium solubility. There was very little uptake of nitrate by the $\mathrm{CSH}$, but sodium did seem to be fixed a little more.

At the Savannah River Plant, Langton et al. (1983) worked on a soluble salt-mixed waste, containing $15.6 \% \mathrm{NaNO}_{3}$ and $3.9 \% \mathrm{NaNO}_{2}$. They had to tailor a cement-based waste form ("saltstone") to have an adjustable set time up to $4 \mathrm{~h}$ and a bulk leach rate of $5-10{\mathrm{~g} . \mathrm{cm}^{-2}}^{-2} \mathrm{day}^{-1}$. Their results showed that the set time was accelerated considerably by the presence of the sodium salts, which were $32 \mathrm{wt} \%$ of the final form. They obtained a projected contaminant release rate, with concentrations below drinking water limits at the site boundary. Another study (Wilhite, 1986), reports the diffusion coefficient for the nitrate from saltstone of $1.04 \times 10^{-8} \mathrm{~cm}^{2} / \mathrm{s}$ for nitrate, equivalent to a leach index of 8 .

Tests reported by Palmer and Smith (1986) concluded that to improve the leachability of nitrate, the use of BFS-portland cement (90-10) was more beneficial than OPC alone. They also measured a retardation effect of nitrate upon the OPC. 
Bouniol (1987) studied the efficiency of various admixtures upon the retention of cesium in a $300 \mathrm{~g} / \mathrm{L} \mathrm{NaNO}_{3}$ solution using a portland cement-BFS-fly ash blend. The initial set time for a neat mortar (sand and blended cement) was $3 \mathrm{~h}$ with water and $4 \mathrm{~h} 20 \mathrm{~min}$ with the concentrated salt solution. The final sets for these materials were $5 \mathrm{~h}$ and $8 \mathrm{~h}$, respectively. The mineralogical composition was found to be almost the same in both the neat mortar with water and the salt containing form. The alumina phase $\left(\mathrm{C}_{2} \mathrm{AH}_{6}\right)$, however, did not appear when the salt was present. There was a delay in the appearance of portlandite caused by $\mathrm{NaNO}_{3}$, as well as a smaller amount of ettringite.

In another study, a surrogate waste containing $300 \mathrm{~g} / \mathrm{L}$ sodium nitrate was immobilized in a cement-based waste form. Vejmelka and Sambell (1984) reported that the hydration and set for this waste form were normal. This was illustrated by SEM examination at 13 days of hydration. Crystals of sodium nitrate were found in the cement matrix, not in the pores as expected, but inside the cement hydrates. These crystals were well developed in contrast to $\mathrm{Ca}(\mathrm{OH})_{2}$ which was not recognized by SEM examination due to the fact that the crystals were too fine to be detected by this technique. Their presence, however, was confirmed by $\mathrm{X}$-ray diffraction. Ettringite was also observed as a hydrated phase.

Dole (1985), in his review of grout development programs, described the complex role of some species contained in nuclear waste streams. He states that the nitrate ion is a mild accelerator at low concentration, but becomes a retarder at high concentration $(>1 M)$.

Spence et al. (1993) designed a model experiment to develop a grout formulation for tank 106-AN at the Hanford site. The simulated waste contained $1.3 M$ nitrate and $0.8 M$ nitrite, as well as $2.4 M$ hydroxides for the major species. Many of the formulations used different additives and mix ratios and resulted in leach indices above 6 for nitrate and nitrite.

Another study using simulated, low-level waste representing that at the Hanford site was performed by Claghorn et al. (1990). They produced and studied 39 solutions containing 6 major species: $\mathrm{AlO}_{2}^{-}(0.06$ to $0.78 M)$, nitrite $(0.13$ to $1.4 M)$, nitrate $(0.2$ to $2.4 M)$, phosphate ( 0 to $0.3 \mathrm{M})$, hydroxide $\left(6.5 \times 10^{-7}\right.$ to $\left.1.2 \mathrm{M}\right)$ and carbonate $(0.06$ to $0.70 \mathrm{M})$. The leach indices obtained were as follows: 8.0 for sodium, 8.1 for nitrite, and 8.0 for nitrate. 
At the Oak Ridge Y-12 Plant, Kass and Lefort (1991) tried to reduce the leachability of nitrate by using slaked and unslaked lime. The nitrate content of the waste solution was $12.4 \%$, added as sodium nitrate. They introduced $40 \%$ of this solution into a dry blend of Class $\mathrm{H}$ portland cement and Class $\mathrm{C}$ fly ash. The addition of $\mathrm{CaO}$ at $7 \%$, based upon the weight of the final waste form, reduced the concentration of nitrate in the leachate from $2533 \mathrm{ppm}$ in the control to $1273 \mathrm{ppm}$ from the mixture containing the calcium oxide.

\subsubsection{Hydroxide}

Hydroxide forms of sodium and potassium are, according to Lea (1971), accelerators for the set of cement. Unfortunately, articles found on this topic discussed waste streams containing various hydroxides usually associated with other species such as nitrate.

In a study by Way and Shayan (1989), various $\mathrm{NaOH}$ solutions were prepared for study. Up to $1 M \mathrm{NaOH}$, the effect upon the normal set was to shorten the dormant period. This resulted in an overall acceleration and was not accompanied by any change in the nature or in the order of appearance of the normal hydrates of portland cement, especially ettringite. At $2 M \mathrm{NaOH}$, there was also an acceleration noticed, as well as a modification of the normal crystallization. At 4.5 $\mathrm{M} \mathrm{NaOH}$, the pastes hardened very fast compared with the other concentrations studied. Ettringite was no longer detected, and new crystalline phases like sodium sulfate and sodium-substituted monosulfate were found.

Very often in complex mixed wastes, hydroxides are found with various salts and/or metals, and it is difficult to distinguish the specific action of each species. One example is given in the study of Cullinane et al. (1987), who synthesized a complex waste with ten interference species, one being $\mathrm{NaOH}$. Cullinane's conclusion was that for the three solid blends studied, (i.e., portland cement, cement/fly ash, and lime/fly ash), the presence of up to 2 wt $\%$ sodium hydroxide, based upon the weight of the waste form, increased the UCS, but that a decrease was obtained for additions between 5 and $8 \mathrm{wt} \%$ sodium hydroxide.

One of the tanks at the Hanford site (106-AN) was studied recently to establish the potential for solidification. Spence et al. (1993) developed a formulation for a complex mixed waste 
containing, among other species, $2.4 \mathrm{M}$ of total hydroxide, including $0.7 \mathrm{M} \mathrm{NaOH}$. The final waste form met the NRC requirements for radioelement leachability for many of the formulations examined. The set time was also in an acceptable range.

Tallent et al. (1988) studied another waste steam from the Hanford site (DSSF), which contained $8.7 \mathrm{M} \mathrm{NaOH}$ and $0.4 \mathrm{M} \mathrm{KOH}$. Despite the concentration, satisfactory leach indices were obtained for both nitrate and ${ }^{99} \mathrm{Tc}$, the most mobile species.

Atkins et al. (1991) studied the effect of alkalies on CSH gels, using sodium hydroxide solutions ranging from 0.25 to $0.80 \mathrm{M} \mathrm{NaOH}$. They saw that there was some uptake of sodium in the $\mathrm{CSH}$ structure and also that $\mathrm{NaOH}$ accelerates the hydration of $\mathrm{C}_{3} \mathrm{~S}$.

\subsubsection{Silicate}

Sodium silicate is used in its active form to accelerate the set of cement (Lea, 1971; Troxell et al., 1968). McVay et al. (1989) at West Valley searched for an additive to counteract an excess of bleed water. They tested, among other additives, sodium silicate and calcium nitrate at 8.4 to $11.2 \mathrm{~g}$ and 7 to $9 \mathrm{~g}$ per $100 \mathrm{~mL}$ of supernatant, respectively. Results obtained showed good processibility up to $9.8 \mathrm{~g}$ sodium silicate and $8.0 \mathrm{~g}$ calcium nitrate. The addition of these compounds improved the processibility, resulted in a higher density, reduced porosity, and increased the compressive strength of the Type I portland cement formulation.

McVay et al. attributed the increase in performance to the addition of excess calcium (calcium nitrate), which increased the mechanical strength, and sodium silicate, which closed the pores. It is also well known that calcium reacts with silicates (as the hydroxide as sodium silicate is quite alkaline) to form a good cement and pore sealing-agent. Troxell et al. (1968) also stated that the action of silicates, like water glass or sodium silicate, was to accelerate the set of portland cement. Soluble silicates are mentioned by Jones (1990) as being credited with forming more stable metal silicates than those formed by metal hydroxides. 


\subsubsection{Borate}

The strong retarding effect of borate and boric acid upon the set of portland cement is very well known. This species is found mainly in evaporator concentrates from nuclear plants. It is also commonly used in the cement industry to retard the set of mortars or concretes.

Even though, in general, all borates are set retarders, some borate compounds are more retarding than others. The study of Bensted et al. (1991) included work with ten different borate compounds, at concentrations of $0.3 \%$ based upon the weight of cement, and found that the most efficient borate retarders are those capable of releasing the most $\mathrm{B}(\mathrm{OH})_{3}$ or $\mathrm{B}(\mathrm{OH})_{4}$ monomer units in solution.

By the proper use of additives in a grout formula, immobilization of borate waste in portland cement can be achieved. Very often a waste pretreatment step will be necessary, however. Jeffrey et al. (1991) report results meeting the regulations for an aqueous waste containing $30 \%$ by weight of neutralized boric acid, with a set time within $24 \mathrm{~h}$. The reported leach indices for cesium and strontium present in the waste were above the NRC-regulated value of 6 .

French evaporator concentrates studied by Bernard and Nomine (1981) contained 25 to $50 \mathrm{~g} / \mathrm{L}$ of boron and were successfully immobilized in cement-based waste forms $\left(400 \mathrm{~L} / \mathrm{m}^{3}\right)$, meeting French nuclear requirements.

According to Vejmelka and Sambell (1984), attempts to immobilize a borate waste solution containing $135.5 \mathrm{~g} / \mathrm{L}$ boric acid and $208.2 \mathrm{~g} / \mathrm{L}$ sodium borate were not able to achieve a set in cement. In this case, the borate solution was not pretreated with $\mathrm{Ca}(\mathrm{OH})_{2}$. Thus, the inhibition of this species upon the set was still present at $\mathbf{3 5}$ days, although some hydration products were identified using $\mathrm{X}$-ray diffraction. $\mathrm{X}$-ray diffraction also revealed the presence of crystallized borate compounds in the waste form, some formed as a result of interactions between the cement and the waste solution. Borax and crystallized borate salts containing calcium $\left(\mathrm{Ca}_{4} \mathrm{~B}_{10} \mathrm{O}_{19} \cdot 7 \mathrm{H}_{2} \mathrm{O}\right)$ were also found. 
After evaporation, British pressurized-water reactors (PWRs), produce salt waste slurries containing $18.5 \%$ sodium borate, of which only $4.5 \%$ is in solution. After pretreatment to precipitate the soluble borate by adding $\mathrm{Ca}(\mathrm{OH})_{2}$ or $\mathrm{Ca}\left(\mathrm{NO}_{3}\right)_{2} \cdot 4 \mathrm{H}_{2} \mathrm{O}$, the final waste-form set time did not exceed 3-4 days (Palmer, 1986).

Other studies performed by Zhou and Colombo (1984) used masonry cement instead of portland cement to circumvent the retardation, or inhibition effect, of borate on portland cement. Zhou stated that as little as $5 \%$ dry boric acid inhibited the hydration of portland cement. He studied a range of boric acid concentrations from 12 to $25 \mathrm{wt} \%$, based upon the weight of the waste form. At a waste loading of $15 \%$, leach indices of radioelements such as ${ }^{85} \mathrm{Sr},{ }^{137} \mathrm{Cs}$ and ${ }^{60} \mathrm{Co}$ were still found to be above 6 , while the set took place within 14 days. The mechanical strength was reduced, however, as a result of the addition of borate.

Simulated borate waste concentrates containing 12 and $24 \%$ by weight boric acid $\left(\mathrm{H}_{3} \mathrm{BO}_{3}\right)$ were stabilized by adding slaked lime and then solidified in a cement-based was te form by Kim et al. (1992). The UCS reached $15 \mathrm{MPa}$ at 28 days. Cobalt, added as a tracer, was evaluated as absent after 120 days: the cumulative fraction leached was less than $0.1 \%$ for the waste form containing $12 \%$ boric acid.

\subsubsection{Phosphate}

Phosphate ions are often found in wastes generated in the nuclear industry. This ion's ability to cause problems is dependent upon what other waste species are present to compete in forming precipitates from the waste solution. In general, phosphate prevents the hydration of cement.

Lea (1971) states that sodium phosphate is a "cement destroyer." Phosphate salts are known to inhibit set time and hardening of cement, sometimes indefinitely. Phosphate compounds can be adsorbed onto the surfaces of cement grains, forming surface precipitates that are too impermeable to allow the hydration mechanism to develop normally. 
Atabek et al. (1990) studied an evaporator concentrate containing $720 \mathrm{~g} / \mathrm{L}$ of salts, of which $\mathrm{NaNO}_{3}$ was present at $150 \mathrm{~g} / \mathrm{L}$ and $\mathrm{Na}_{3} \mathrm{PO}_{4} \cdot 12 \mathrm{H}_{2} \mathrm{O}$ at $428 \mathrm{~g} / \mathrm{L}$. They found that part of the sodium phosphate was transformed into calcium phosphate, which is more stable and highly insoluble. One of the conclusions of their study was that the release of radionuclides appears to result from a competition between porosity and chemical fixation. However, in their surrogate, the addition of phosphate was beneficial because it improved the retention of strontium in the matrix due to precipitation as the phosphate salt of strontium. This benefit occurred as a result of substitution of calcium by strontium during the crystallization of hydroxylapatite.

At the Hanford site (Rebagay and Dodd, 1989), the Grout Treatment Facility had to immobilize a phosphate-sulfate waste containing $0.11 \mathrm{M}$ phosphate in the simulated waste. Also present in the surrogate were sulfate $(0.03 M)$, nitrate (1.5 $M)$ and sodium (5.1 $M)$. The reported leach index obtained for phosphate was 10.9 , which was much better than for nitrate $(\sim 7.5)$ and sulfate $(\sim 8.3)$. This result suggests that there is fixation of phosphate in the host matrix components.

Another study performed for the Hanford site by Sams et al. (1988) and Lokken et al. (1987) used a waste containing $0.36 \mathrm{M}$ phosphate and $1.1 \mathrm{M}$ sodium. Immobilization led to an acceptable final waste form meeting the NRC requirements as well as the process requirements. The reference formula used produced acceptable grouts that were processible and durable. The final grouts were found to pass the Extraction Procedure (EP)-Toxicity test.

The role of the associated cation in the presence of phosphate anions seems to be of great importance. Calcium phosphate, which is very insoluble, does not seem to present as many problems as more soluble forms do. Kertesz et al. (1990) worked on a phosphated ash waste composed of calcium pyrophosphate $\left(\mathrm{Ca}_{2} \mathrm{P}_{2} \mathrm{O}_{7}\right)$. They incorporated $30 \%$ of this waste in a $10 \%$ OPC - 90\% BFS blended cement. Their study did not address leachability, bis the waste form set without difficulty. 


\subsubsection{Fluoride}

Fluoride has been found to be an accelerator for $\mathrm{C}_{3} \mathrm{~A}$ hydration and a retarder for $\mathrm{C}_{3} \mathrm{~S}$. This compound does not seem to be a major waste species in the studies examined in the literature search. Conner (1990) indicates that fluoride can be easily insolubilized as calcium fluoride $\left(\mathrm{CaF}_{2}\right)$, and because of the large amount of calcium present in cement-based systems, this species is not known to present a problem for stabilization.

Table 1 presents data concerning anionic waste species that can potentially interfere with cement-based stabilization processes. The table summarizes the experiences of many researchers, and the expected levels of sensitivity of the various species to produce the observed effects are shown. 
Table 1 Summary data of anionic species

\begin{tabular}{|c|c|c|c|}
\hline Species & Concentrations employed & Observed effect & Reference $^{c}$ \\
\hline \multirow[t]{8}{*}{ Borates } & $\oplus 0.3 \mathrm{wt} \%$ various borate salts / cement & Retarder & Bensted et al., 1991 \\
\hline & $\bullet 30$ wt \% neutralized boric acid / waste form & Retarder & Jeffrey et al, 1991 \\
\hline & - $5 \mathrm{wt} \%$ dry boric acid / OPC waste form & Inhibition of the set & Zhou and Colombo, 1984 \\
\hline & $\begin{array}{l}135.5 \mathrm{~g} / \mathrm{L} \text { boric acid }+208.2 \mathrm{~g} / \mathrm{L} \text { sodium borate } \\
\text { solution }\end{array}$ & Inhibition of the set & Vejmelka and Sambell, 1984 \\
\hline & - $\left[\mathrm{H}_{3} \mathrm{BO}_{3}\right]=12$ and $24 \%$ solutions & Feasible & Kim et al., 1992 \\
\hline & -Slurries containing $18.5 \%$ sodium borate & Set in $3-4$ days & Palmer and Smith, 1986 \\
\hline & $\bullet 25$ to $50 \mathrm{~g} / \mathrm{L}$ boron solution & Set achieved & Bernard and Nomine, 1981 \\
\hline & $\begin{array}{l}\bullet 15 \text { wt \% boric acid / masonry cement-based waste } \\
\text { form }\end{array}$ & $\begin{array}{l}\text { Radioelements LI >6 } \\
\text { Set within } 14 \text { days, durability } \\
\text { and UCS poor }\end{array}$ & Zhou and Colombo, 1984 \\
\hline \multirow[t]{7}{*}{ Carbonates } & -Alkali carbonates 1 to $2 \mathrm{wt} \%$ / cement & Strong accelerator & Lea, 1971 \\
\hline & $\bullet \mathrm{K}_{2} \mathrm{CO}_{3}=0.25 \mathrm{wt} \% /$ cement & Retarder & Lea, 1971 \\
\hline & $-\mathrm{K}_{2} \mathrm{CO}_{3}>0.25 \mathrm{wt} \% /$ cement & $\begin{array}{l}\text { Accelerator and flash set } \\
\text { possible }\end{array}$ & Lea, 1971 \\
\hline & $\mathrm{Na}_{2} \mathrm{CO}_{3}$ solutions: & & \\
\hline & $\begin{array}{l}\bullet 1.7 \mathrm{wt} \% \mathrm{Na}_{2} \mathrm{CO}_{3} \text { and } 38 \text { to } 48 \% \text { waste } \\
\text { solution loading }\end{array}$ & Set achieved & Langton et al., 1983 \\
\hline & $\bullet 0.3 \mathrm{M} \mathrm{Na}_{2} \mathrm{CO}_{3}$ solution & Set achieved & Tallent et al., 1988 \\
\hline & $\bullet .702 \mathrm{M} \mathrm{Na}_{2} \mathrm{CO}_{3}$ solution & Set achieved & Claghorn et al., 1990 \\
\hline
\end{tabular}


Table 1 (continued)

\begin{tabular}{|c|c|c|c|}
\hline Species & Concentrations employed a & Observed effect ${ }^{b}$ & Reference $^{c}$ \\
\hline \multirow[t]{7}{*}{ Chlorides } & $\begin{aligned} &-\mathrm{CaCl}_{2} \\
&<1 \text { wt } \% / \text { cement } \\
& 2 \text { wt } \% / \text { cemeri } \\
& 3 \text { wt } \% / \text { cement }\end{aligned}$ & $\begin{array}{l}\text { Retarder } \\
\text { Accelerator } \\
\text { Flash set }\end{array}$ & Troxell et al., 1968 \\
\hline & $\bullet \mathrm{NaCl}$ & & \\
\hline & 2 to $3.5 \mathrm{wt} \%$ as $\mathrm{NaCl} /$ cement & Accelerator & Taylor, 1990 \\
\hline & $\begin{array}{c}\bullet \mathrm{NH}_{4} \mathrm{Cl}, \mathrm{FeCl}_{2}, \mathrm{FeCl}_{3}, \mathrm{CoCl}_{2} \\
<2 \mathrm{wt} \% / \text { cement } \\
>2 \mathrm{wt} \% / \text { cement }\end{array}$ & $\begin{array}{l}\text { Retarder } \\
\text { Accelerator }\end{array}$ & Lea, 1971 \\
\hline & $\bullet 31 \mathrm{~g} / \mathrm{L} \mathrm{Cl}$ solution (seawater) & Slight accelerator & Ghorab et al., 1990 \\
\hline & $\bullet 2.8$ wt $\%$ salt / cement-based waste form & $\begin{array}{l}\text { Set time: several hours } \\
\text { LI } 7 \text { to } 8(\mathrm{Cl})\end{array}$ & Fischer and Johnson, 1988 \\
\hline & $\bullet 10 \mathrm{wt} \%$ salt / mortar waste forms & $\begin{array}{l}\text { LI > } 6 \\
\text { Decrease of UCS }\end{array}$ & Fischer and Johnson, 1988 \\
\hline \multirow[t]{6}{*}{ Hydroxides } & $\bullet 8.73 M \mathrm{NaOH}+0.44 M \mathrm{KOH}$ solution & Set achieved & Tallent et al., 1988 \\
\hline & $\bullet 2.36 M$ total hydroxide solution & Set achieved & Spence et al., 1993 \\
\hline & $\bullet 1.24 M \mathrm{NaOH}$ solution & Set achieved & Claghorn et al., 1990 \\
\hline & $\begin{array}{l}-[\mathrm{NaOH}]<1 M \text { solution } \\
{[\mathrm{NaOH}]=2 M \text { solution }} \\
{[\mathrm{NaOH}]=4.5 M \text { solution }}\end{array}$ & $\begin{array}{l}\text { Accelerator } \\
\text { Accelerator } \\
\text { Strong accelerator }+ \\
\text { modification of the structure }\end{array}$ & Way and Shayan, 1989 \\
\hline & $\bullet 0.25$ to $0.80 \mathrm{M}$ & Accelerator & Atkins et al., 1991 \\
\hline & $\begin{array}{l}-2 \mathrm{wt} \% \text { / waste form } \\
-5 \text { to } 8 \mathrm{wt} \% \text { / waste form }\end{array}$ & $\begin{array}{l}\text { Increase of UCS } \\
\text { Decrease of UCS }\end{array}$ & Cullinane et al., 1987 \\
\hline
\end{tabular}


Table 1 (continued)

\begin{tabular}{|c|c|c|c|}
\hline Species & Concentrations employed " & Observed effect ${ }^{b}$ & Reference $^{c}$ \\
\hline \multirow[t]{11}{*}{ Nitrate } & $\begin{array}{l}-\mathrm{NO}_{2}(0.13 \text { to } 1.39 M)+\mathrm{NO}_{3} \\
(0.22 \text { to } 2.36 M)\end{array}$ & $\begin{array}{l}\mathrm{LI} \mathrm{NO}=8.0 \\
\mathrm{LI} \mathrm{NO}=8.1\end{array}$ & Claghorn et al., 1990 \\
\hline & $\bullet 12.4 \% \mathrm{NaNO}_{3}$ solution & Set achieved & Kass and Lefort, 1991 \\
\hline & $\begin{array}{l}-15.6 \% \mathrm{NaNO}_{3}+3.9 \mathrm{wt} \% \mathrm{NaNO}_{2} \text { solution (38 to } \\
48 \% \text { solution in final waste form) }\end{array}$ & $\begin{array}{l}\text { Accelerator } \\
\text { LI }-8\end{array}$ & $\begin{array}{l}\text { Langton, } 1989 \\
\text { Wilhite, } 1986\end{array}$ \\
\hline & $\bullet 1.5 \mathrm{M} \mathrm{NO}_{3}$ solution & $\mathrm{LI}=7.4$ & Rebagay and Dodd, 1989 \\
\hline & -144 $\mathrm{g} / \mathrm{L} \mathrm{NO}_{3}$ solution & Accelerator & Bouniol et al., 1988 \\
\hline & -300 g/L $\mathrm{NaNO}_{3}$ solution & Slight retarder & Bouniol, 1987 \\
\hline & - $300 \mathrm{~g} / \mathrm{L} \mathrm{NaNO}$ solution & Normal properties & Vejmelka and Sambell, 1984 \\
\hline & $\begin{array}{l}-\left[\mathrm{NO}_{3}\right]<1 M \text { solution } \\
{\left[\mathrm{NO}_{3}\right]>1 M \text { solution }}\end{array}$ & $\begin{array}{l}\text { Slight accelerator } \\
\text { Retarder }\end{array}$ & Dole, 1985 \\
\hline & $\bullet 1.33 \mathrm{MNO}_{3}+0.76 \mathrm{MNO}_{2}$ solution & LI $>6$ & Spence et al., 1993 \\
\hline & $\bullet 1.5 \mathrm{M} \mathrm{Al}\left(\mathrm{NO}_{3}\right)_{3}$ solution & $\mathrm{LI}>7$ & Tallent et al, 1988 \\
\hline & 055 wt \% dry nitrate salt / waste form & $\begin{array}{l}\text { Accelerator (poor leaching } \\
\text { properties expected) }\end{array}$ & Petersen et al., 1986 \\
\hline \multirow[t]{5}{*}{ Phosphate } & $\bullet .305 \mathrm{M} \mathrm{Na}_{2} \mathrm{PO}_{4}$ solution & Set achieved & Claghorn et al., 1990 \\
\hline & $\bullet 0.11 \mathrm{M} \mathrm{PO}_{4}$ solution & $L I=10.9$ & Rebagay and Dodd, 1989 \\
\hline & e.36 $\mathrm{MPO}_{4}$ solution & Set achieved & Sams et al., 1988 \\
\hline & $\begin{array}{l}-428 \mathrm{~g} / \mathrm{L} \mathrm{Na} \mathrm{NO}_{4} \cdot 12 \mathrm{H}_{2} \mathrm{O} / \text { mixed salts waste } \\
\text { solution }\end{array}$ & Set achieved & Atabek et al., 1990 \\
\hline & $\bullet 30$ wt \% $\mathrm{Ca}_{2} \mathrm{P}_{2} \mathrm{O}_{7} /$ waste form & Set achieved & Kertesz et al., 1990 \\
\hline
\end{tabular}


Table 1 (continued)

\begin{tabular}{|c|c|c|c|}
\hline Species & Concentrations employed * & Observed effect ${ }^{b}$ & Reference $^{c}$ \\
\hline Silicates & $\bullet 8.4$ to $11.2 \mathrm{~g}$ sodium silicate / $100 \mathrm{~mL}$ supernatant & Increase of UCS & McVay et al., 1989 \\
\hline \multirow[t]{8}{*}{ Sulfate } & - 4 wt $\% \mathrm{CaSO}_{4} \cdot 1 / 2 \mathrm{H}_{2} \mathrm{O} /$ cement & Accelerator & Lea, 1971 \\
\hline & $\mathrm{Na}_{2} \mathrm{SO}_{4}$ & & \\
\hline & $\begin{array}{l}1.9 \text { wt \% solution ( } 38 \text { to } 48.56 \text { solution in } \\
\text { final waste form) }\end{array}$ & Accelerator & Langton, 1989 \\
\hline & $\bullet 225 \mathrm{~g} / \mathrm{L}$ solution & Set achieved & Vejmelka and Sambell, 1984 \\
\hline & $21.1 \%$ solution & Set achieved & De Angelis et al., 1992 \\
\hline & 0.12 wt $\%$ / cement & Set achieved & Palmer and Smith, 1986 \\
\hline & $\bullet 2.7$ wt \% / solution & Set achieved & McVay et al., 1989 \\
\hline & $\bullet 9 \mathrm{wt} \%$ / waste form & Set achieved & Zhou and Colombo, 1984 \\
\hline
\end{tabular}

" A solidus or slash (I) preceded and followed by a space is used to indicate based upon the weight of." OPC = Ordinary portland cement.

- $\mathbf{L I}=$ leach index; UCS = unconfined compressive strength

c Complete citations are included in the reference section of this report. 


\subsection{HEAVY METALS}

Most researchers state that heavy metals are very often well stabilized in cement-based matrices but that there are differences in how they are retained in the matrix. Some waste streams will require pretreatment before their solidification in cement-based waste forms. Sludge generation prior to immobilization, such as that which occurs with metal-containing wastewaters, is usually subject to hydroxide precipitation.

Idaho National Engineering Laboratory (INEL, 1992) and Grosse (1991) reviewed waste treatment processes and summarized their findings as follows.

1. Metal removal can be achieved by hydroxide precipitation and is effective for As, Cd, $\mathrm{Cr}(\mathrm{III}), \mathrm{Cu}, \mathrm{Fe}, \mathrm{Mn}, \mathrm{Ni}, \mathrm{Pb}$, and $\mathrm{Zn}$. Sulfide precipitation is very effective for $\mathrm{As}, \mathrm{Cd}, \mathrm{Co}$, $\mathrm{Cu}, \mathrm{Fe}, \mathrm{Hg}, \mathrm{Mn}, \mathrm{Ni}, \mathrm{Ag}, \mathrm{Sn}$, and $\mathrm{Zn}$. In addition, carbonate precipitation is effective for $\mathrm{Cd}, \mathrm{Ni}$, and $\mathrm{Pb}$.

2. Reduction is mainly utilized for $\mathrm{Cr}, \mathrm{Hg}, \mathrm{Cu}, \mathrm{Ag}$, and soluble lead. This process usually uses sodium sulfite or ferrous sulfate salts as reducing agents to form less soluble forms of these metals.

Choosing the correct pretreatment is important because it may influence the results of the Toxicity Characteristic Leaching Procedure (TCLP) test of the final waste form. On the other hand, some of these metals can also inhibit the set of cement. Results of the literature search that focus on modification of the set time and leachability are presented for specific heavy metals as follows.

\subsubsection{Zinc}

The effect of soluble zinc present in waste streams, including metallic zinc, was discussed widely in the literature. Troxell et al. (1968) mentioned the use of metallic zinc or aluminum powder to produce low-strength cellular concrete. In the presence of alkalies liberated during the hydration of cement, the metal powders will form hydrogen gas. To produce such 
an effect, the authors stated that a concentration of 0.005 to $0.02 \%$ zinc, based upon the weight of cement, was necessary.

A fundamental study performed by Arliguie and Grandet (1990a), explained the fixation of the zinc ion in the presence of portland cement. They discussed the action of zinc on the set of the two most important mineralogical phases of cement, that is, tric:alcium silicate $\left(\mathrm{C}_{3} \mathrm{~S}\right)$ and tricalcium aluminate $\left(C_{3} A\right)$. The $C_{3} S$ hydration is always delayed in the presence of zinc due to the formation of a layer of amorphous zinc hydroxide $\mathrm{Zn}(\mathrm{OH})_{2}$. They also report that when the concentration of sulfate in the cement is above $4 \%$, the set will not occur.

The resulting effect of adding 5\% zinc, based upon the weight of cement, will, for the hydration of $\mathrm{C}_{3} \mathrm{~A}$, be a function of the concentration of sulfate in the cement already. $U p$ to $2.5 \%$ sulfate, there is an accelerating effect on $\mathrm{C}_{3} \mathrm{~A}$ hydration that releases larger amounts of $\mathrm{Ca}^{2+}$ and $\mathrm{OH}^{-}$ions into the interstitial solution. These ions will transform the layer of $\mathrm{Zn}(\mathrm{OH})_{2}$ present around $\mathrm{C}_{3} \mathrm{~S}$ into the hydroxyzincate of calcium, and, as a result, the hydration of $\mathrm{C}_{3} \mathrm{~S}$ can resume.

When the concentration of sulfate exceeds $2.5 \%$, the hydration of $\mathrm{C}_{3} \mathrm{~A}$ is retarded. Arliguie and Grandet observed that the layer of ettringite around the $\mathrm{C}_{3} \mathrm{~A}$ grains is denser and finer, thus slowing the contact of solution with anhydrous material. In this case, there is no counteracting effect upon the retardation of $\mathrm{C}_{3} \mathrm{~S}$ hydration, and the total system will be retarded by concentrations up to $5.5 \%$ sulfate; a concentration of $5.5 \%$ will completely inhibit the set.

In another study, Arliguie and Grandet (1990b) measured the set time of four commercial cements containing different proportions of $\mathrm{C}_{3} \mathrm{~A}$ and free calcium oxide $(\mathrm{CaO})$, with and without the addition of $5 \%$ zinc. The set time was increased by a factor as high as 30 upon adding $5 \%$ zinc, based upon the weight of cement. The higher the amount of free $\mathrm{CaO}$ or $\mathrm{C}_{3} \mathrm{~A}$, the smaller the retardation was.

Previous conclusions concerning the physical inhibition of calcium silicates by zinc are confirmed in other studies like those of Ortego et al. (1989) and Cocke (1990), who used 
different techniques such as Fourier transformed infrared (FTIR), thermogravimetrical analysis (TGA), and SEM. With these techniques, researchers could observe the interference of zinc in cement. The interference of this metal is even more pronounced than of others such as lead.

The work of Cullinane et al. (1987) illustrates this retardation phenomenon and indicates the level at which zinc nitrate induces interference upon the UCS. They report the following results of 28-day UCS as a positive or negative percent change based upon the control specimen, made with a portland cement binder. Ratios of the concentration of $t \mathrm{t}-\mathrm{Zn}\left(\mathrm{NO}_{3}\right)_{2}$ to the cement-plus-sludge are shown in the following list (the UCS percent variation compared with the control is indicated parenthetically):

- $0.02(+3)$

- $0.05(-73)$

- $0.08(-86)$

Tashiro et al. (1979) reporte' the same results as above, that is, a decrease of $71 \%$ in the UCS when $5 \% \mathrm{ZnO}$ was added to a cement mortar.

In several papers, Poon and his coworkers reported the effects of incorporating zinc nitrate (Poon et al., 1985, 1986; Poon and Perry, 1987). They examined the UCS, leaching properties, and microstructure of portland cement, with and without admixtures, upon adding $\mathrm{Zn}\left(\mathrm{NO}_{3}\right)_{2}$. The mechanical properties of an OPC/pulverized fuel ash (PFA) admixture containing $2 \% \mathrm{Zn}\left(\mathrm{NO}_{3}\right)_{2}$ and a control without zinc were similar to the effects described above.

Zinc has a strong retarding effect upon set because it forms a layer of amorphous gel on cement particulates. A study of the microstructure of zinc-containing waste forms reveals that the porosity is increased as a result of the formation of large crystals of ettringite and calcium monosulfoaluminates. 
Leaching studies of cement containing zinc show low concentrations of this metal in the leachates. An acetic acid leach test of a $0.2 \%$ solution of zinc released $0.32 \mathrm{ppm}$ from an OPC/PFA mixture and $1.8 \mathrm{ppm}$ from an OPC/silicate mixture.

Nine listed wastes were processed using portland cement in a study by Bricka and Cullinane (1990). Among the contaminants was zinc at a concentration in the raw composite of $2.61 \mathrm{mg} / \mathrm{L}$. The compressive strength developed by the cement-based waste form was about 1500 psi. The concentration of zinc in the TCLP leachate of the raw waste was $0.236 \mathrm{mg} / \mathrm{L}$ and $0.02 \mathrm{mg} / \mathrm{L}$ from the treated waste.

At the New Bedford Harbor Superfund site, Myers and Zappi (1992) worked with a waste sediment containing various metals. They studied different $S / S$ processes, including two that were portland cement based. Their results are summarized in the following table.

\begin{tabular}{lccc}
\hline Species & $\begin{array}{c}\text { Composite } \\
\text { sediment } \\
\text { concentration } \\
(\mathrm{mg} / \mathrm{kg})\end{array}$ & $\begin{array}{c}\text { Amount of metal } \\
\text { leached from } \\
\text { untreated sediment } \\
(\mathrm{mg} / \mathrm{kg})\end{array}$ & $\begin{array}{c}\text { Amount of metal leached } \\
\text { from cement-based } \\
\text { treated sediment } \\
(\mathrm{mg} / \mathrm{kg})\end{array}$ \\
\hline Cadmium & 35.4 & 0.113 & $<0.003$ \\
Chromium & 754 & 2.99 & 1.13 to $2.47^{2}$ \\
Copper & 1730 & 3.72 & 77.6 to $87.8^{2}$ \\
Lead & 2013 & 3.14 & 0.72 \\
Nickel & 122 & 0.57 & 5.5 to $8.96^{\mathrm{a}}$ \\
Zinc & 3017 & 13.1 & 0.88 to $1.44^{2}$ \\
\hline Value depending upon the admixtures used in the formulation.
\end{tabular}

The S/S process increased the amount of copper and nickel leached when compared with the untreated sample. Myers and Zappi do not have an explanation for this phenomenon and state that it has been observed by other researchers as well.

One of the five wastes presented in the study of Stegeman and Cote (1990) contained zinc as a pollutant, at a concentration of $900 \mathrm{mg} / \mathrm{kg}$ in a dredged sediment. The TCLP test was 
performed on the raw waste and exhibited a concentration of $0.24 \mathrm{mg} / \mathrm{L}$. Fifteen industrial proprietary solidification processes were tested on this waste. The TCLP concentrations of the solidified products ranged between 0.085 and $19.7 \mathrm{mg} / \mathrm{L}$, with three samples being below the detection limit.

\subsubsection{Cadmium}

Generally the literature states that cadmium can be fixed efficiently in cement-based waste forms. The cadmium-cement system generates $\mathrm{Cd}(\mathrm{OH})_{2}$ precipitates, which provide sites for the nucleation of hydrated cement phases: $\mathrm{CSH}$ and portlandite (Butler et al., 1990; Brown and Bishop, 1985).

This chemical fixation mechanism has been confirmed by Poon et al. (1986) in their permeability study. They used a $2 \% \mathrm{Cd}\left(\mathrm{NO}_{3}\right)_{2}$ solution to prepare the waste form samples. The measured UCS for three types of binders gave comparable results for the control and the cadmium-doped sample. The porosity of the doped sample was found to be above that of the control. This result was confirmed by the work of Campbell et al. (1987), who attributed this increase in porosity to the formation of abundant colloidal ettringite.

A study by Ortego (1990) confirmed that cadmium stabilization is enhanced by sulfide, which forms a very insoluble CdS precipitate. He performed a modified TCLP test, which consisted of seven consecutive extractions in an acetic acid solution, on two types of portland cement formulations containing $10 \mathrm{wt} \%$ cadmium nitrate in the waste form. The first formulation used portland cement alone, and the second had sodium sulfide added. The results are presented in the following table.

\begin{tabular}{lccc}
\hline & \multicolumn{3}{c}{ Cumulative extraction (\%) } \\
\hline & 1 day & 3 days & 7 days \\
Portland cement & 0.01 & 2.74 & 42.24 \\
Cement containing sulfide & 0.01 & 0.07 & 21.95 \\
\hline
\end{tabular}


Poon et al. (1987) incorporated a $2000-\mathrm{ppm} \mathrm{Cd}\left(\mathrm{NO}_{3}\right)_{2}$ solution in an $\mathrm{OPC} /$ silicate mixture and in an OPC/PFA mixture. After 5 days of leaching in an acetic acid solution, they measured a concentration of cadmium in the leachate of $0.01 \mathrm{ppm}$ for both mixtures.

Heimann and his coworkers (1992) studied the leachability of some heavy metals stabilized in different cement-based waste forms. Their conclusion regarding the stabilization of cadmium was that this species, if incorporated in a concentration range of 2200 to $27,000 \mathrm{mg} / \mathrm{kg}$ of cement paste, was very well retained in all three matrices evaluated. The leachability of cadmium was found to be below their 0.1-ppm detection limit.

A contaminated soil containing 10,000 ppm cadmium was stabilized by Akhter et al. (1990). They used different combinations of additives mixed with Type I portland cement. They evaluated the best formulation by the use of a modified EP Toxicity l ach test. The leachate concentration of the raw soil was $338 \mathrm{ppm}$. After an addition of $10 \%$ Type I portland cement plus $10 \%$ slag, the waste form released only $0.48 \mathrm{ppm}$. Among those studied, this type of mixture (OPC and BFS) seemed to be the most efficient in maintaining cadmium in the waste form. The authors stated that cadmium hydroxide was precipitated in an early stage during the hydration process and was serving as nuclei for the formation of CSH.

Chemical immobilization of heavy metals wastewaters is usually accomplished by utilizing hydroxide precipitation. Bricka and Hill (1989) studied another alternative to hydroxide precipitation, that is, using cellulose and starch xanthate to immobilize the heavy metals species. The cadmium concentrations in the sludges studied were, respectively, $19.9 \mathrm{mg}$ of cadmium per gram of dry cellulose sludge, $33.3 \mathrm{mg} / \mathrm{g}$ in a starch sludge, and $16.4 \mathrm{mg} / \mathrm{g}$ in the hydroxide sludge. The resulting sludges were solidified using Type I portland cement. The EP Toxicity leach tests were performed on these materials, and the results are presented in the following table. 


\begin{tabular}{lccc}
\hline & & \multicolumn{2}{c}{ Nature of the sludge } \\
\cline { 2 - 4 } & Starch & Cellulose & Hydroxide \\
\hline $\begin{array}{l}\text { Concentration of cadmium in the raw } \\
\text { sludge }(\mathrm{mg} / \mathrm{g})\end{array}$ & 33.3 & 19.9 & 16.4 \\
$\begin{array}{l}\text { Concentration of cadmium in the } \\
\text { leachate of the raw sludge }(\mathrm{mg} / \mathrm{L})\end{array}$ & 0.303 & 26.05 & 57.93 \\
$\begin{array}{l}\text { Concentration of cadmium in the } \\
\text { leachate of the solidified sludge }(\mathrm{mg} / \mathrm{L})\end{array}$ & $<0.0001$ & $<0.0001$ & $<0.0001$ \\
\hline
\end{tabular}

Jones et al. (1992) studied a synthetic waste treatment sludge containing $\mathrm{Cd}, \mathrm{Cr}, \mathrm{Hg}$, and $\mathrm{Ni}$. They tested different $\mathrm{S} / \mathrm{S}$ systems and examined the interferences created by adding other species to those already present in the waste. This sludge contained $6330 \mathrm{mg}$ cadmium per kilogram of dry sludge. The EP Toxicity test on the raw sludge resulted in a concentration of $57.9 \mathrm{mg} / \mathrm{L}$ cadmium in the leachate. The sludge stabilized in a portland cement-based matrix resulted in a concentration of only $0.0021 \mathrm{mg} / \mathrm{L}$.

In a study by Stegemann and Cote (1990), five hazardous wastes containing various contaminants were solidified using 15 industrial processes existing at the development or commercial stage. The resulting solidified products were studied by five independent laboratories that performed various tests, among them TCLP, to evaluate the performances of these waste forms. Leaching data for cadmium are summarized in the following table.

\begin{tabular}{lccc}
\hline Waste ID & $\begin{array}{c}\text { Concentration of } \\
\text { cadmiun in the raw } \\
\text { waste }(\mathrm{mg} / \mathrm{kg})\end{array}$ & $\begin{array}{c}\text { TCLP concentration } \\
\text { of cadmium of the } \\
\text { raw waste }(\mathrm{mg} / \mathrm{L})\end{array}$ & $\begin{array}{c}\text { Range of TCLP } \\
\text { concentration of the } \\
\text { solidified waste }(\mathrm{mg} / \mathrm{L})\end{array}$ \\
\hline $\begin{array}{l}\text { WTS solution } \\
\text { WES sludge }\end{array}$ & 4600 & 4600 & $\mathrm{ND}-31.5^{\mathrm{a}}$ \\
\hline ND = non detected & 4000 & $<0.004$ & $\mathrm{ND}-0.091^{\mathrm{b}}$ \\
$\begin{array}{l}\text { Six of 14 solidified products had TCLP concentration below the detection limit } \\
\text { Twelve of 14 solidified products had concentration below the detection limit }\end{array}$
\end{tabular}




\subsection{Mercury}

Elemental mercury, due to its volatility, is difficult to stabilize, and is sparingly soluble in polar and nonpolar solvents. Many publications show that retention of this species in cement-based waste forms is not very efficient because mercury does not exist as a strong surface-absorbing species.

McWhinney and coworkers (1990) studied the mechanism of mercury fixation in portland cement. They incorporated a $10 \%$ by weight aqueous mercuric nitrate in Type I portland cement and observed an instantaneous precipitate of mercuric oxide $(\mathrm{HgO})$ when the solution touched the cement. This precipitate is retained in the matrix by physical, not chemical, sorption. They did not see, with the techniques employed, evidence of any chemical bond formation between mercury and the cement. They also noticed that the fairly insoluble precipitate of mercuric oxide $(\mathrm{HgO})$ has the potential to retard the set by coating the calcium silicate and thus preventing a normal hydration.

Poon and Periy (1987) and Poon et al. (1986) evaluated the retention of mercury in portland cement-based waste forms. They incorporated a $0.2 \%$ solution of mercuric chloride and a $0.2 \%$ solution of mercuric nitrate. Five-day leaching tests resulted in concentrations of 5.4 and $1.2 \mathrm{ppm}$ in the leachate for mercuric chloride, depending upon the formulation used. The measured UCS was higher than for the control, due to the accelerating effect of the chloride when using mercuric chloride. When using $2 \% \mathrm{HgCl}_{2}$ and $3 \% \mathrm{Hg}\left(\mathrm{NO}_{3}\right)_{2}$ in solution, they obtained a UCS usually higher than that of the control sample.

In the case of the nitrate salt, the leaching test yielded $0.7 \mathrm{ppm}$ in the leachate. The effect upon the UCS was not as beneficial as it was for the chloride salt, as the UCS result was below the control. The authors also noticed a slight retardation effect of $\mathrm{Hg}\left(\mathrm{NO}_{3}\right)_{2}$ upon the set.

Clark et al. (1985) also studied the immobilization of mercury in cement-based systems. They observed that a $2 \%$ solution of mercury did not seriously affect the hydration of portland cement. The inability of mercury to form an insoluble hydroxide or silicate upon 
incorporation in cement indicates that this metal species is physically encapsulated in the matrix. Therefore, mercury ion leachabjlity will be sensitive to the permeability of the solidified waste form alone. In this study, Clark and coworkers obtained $131 \mathrm{ppm}$ of mercury in their leachates.

In their demonstration of the best available technology for various RCRA wastes, Bricka and Cullinane (1990) used portland cement as one of the binders for the fixation of many heavy metals. The raw waste composite they treated contained $25,900 \mathrm{mg} / \mathrm{L}$ of mercury. The resulting concentration of mercury in the TCLP leachate of the raw waste was $0.1 \mathrm{mg} / \mathrm{L}$. Upon stabilization with portland cement, the TCLP concentration of mercury increased, surprisingly, to $28.6 \mathrm{mg} / \mathrm{L}$. This is a demonstration that cement solidification may not be the best stabilization method for mercury.

Bricka and Hill (1989) compared the efficiency of three types of pretreatment-hydroxide, starch, and cellulose precipitation-for heavy metals present in wastewaters. After the precipitation process was completed, the resulting sludges were solidified in Type I portland cement. The authors evaluated the efficiency of the containment of the pollutants by using the EP Toxicity leach test. The results of these tests are presented in the following table.

\begin{tabular}{lccc}
\hline & \multicolumn{3}{c}{ Nature of the sludge } \\
\cline { 2 - 4 } & Starch & Cellulose & Hydroxide \\
\hline $\begin{array}{l}\text { Concentration of mercury in the raw } \\
\text { sludge (milligram of mercury per gram } \\
\text { of dry sludge) }\end{array}$ & 1.15 & 0.64 & 0.97 \\
$\begin{array}{l}\text { Concentration of mercury in the } \\
\text { leachate of the raw sludge (mg/L) }\end{array}$ & $<0.0008$ & 0.0133 & 0.8392 \\
$\begin{array}{l}\text { Concentration of mercury in the } \\
\text { leachate of the solidified sludge }(\mathrm{mg} / \mathrm{L})\end{array}$ & $<0.0008$ & 0.002 & 0.565 \\
\hline
\end{tabular}

Jones et al. (1992) studied a treatment of synthetic metal sludge containing $\mathrm{Cd}, \mathrm{Cr}, \mathrm{Hg}$, and Ni. They tested three different $\mathrm{S} / \mathrm{S}$ systems and examined the interference created by adding, one at a time, ten other species, organic and inorganic, to those already present in the waste. The results related to the interfering species will not be presented in this work: only the 
metal sludge leaching results obtained using the EP Toxicity leaching test are presented in the following table.

\begin{tabular}{lcccc}
\hline & \multicolumn{4}{c}{ Concentration } \\
\cline { 2 - 5 } Species & $\mathrm{Cd}^{2+}$ & $\mathrm{Cr}^{3+}$ & $\mathrm{Hg}^{2+}$ & $\mathrm{Ni}^{2+}$ \\
Sludge (mg/kg dry wt) & 6,330 & 3,170 & 44 & 29,350 \\
$\begin{array}{l}\text { EP Toxicity raw sludge }(\mathrm{mg} / \mathrm{L}) \\
\begin{array}{l}\text { EP Toxicity of portland } \\
\text { cement-based matrix (mg/L) }\end{array}\end{array}$ & 57.9 & 242 & 0.84 & 149 \\
$\begin{array}{l}\text { EP Toxicity of portland cement } \\
\text { plus fly ash matrix (mg/L) }\end{array}$ & 0.0021 & 0.010 & 0.95 & 0.083 \\
\hline
\end{tabular}

In a study by Stegeman and Cote (1990), 5 hazardous wastes containing various contaminants were solidified using 15 industrial cement-based processes existing at development or commercial stage. The resulting solidified products were studied by five independent laboratories that performed various tests, among them TCLP, to evaluate and compare the performances of these waste forms. Leaching data for mercury are summarized in the following table.

\begin{tabular}{lccc}
\hline Waste ID & $\begin{array}{c}\text { Concentration in } \\
\text { the raw waste } \\
(\mathrm{mg} / \mathrm{kg})\end{array}$ & $\begin{array}{c}\text { TCLP concentration } \\
\text { of the raw waste } \\
(\mathrm{mg} / \mathrm{L})\end{array}$ & $\begin{array}{c}\text { Range of the TCLP } \\
\text { concentration of the } \\
\text { solidified waste }(\mathrm{mg} / \mathrm{L})\end{array}$ \\
\hline WES solution & 200 & 2.8 & $\mathrm{ND}-3.1^{\mathrm{a}}$ \\
$\begin{array}{l}\text { Dredged sediment } \\
\text { Wood waste soil }\end{array}$ & 0.7 & 0.0006 & $\mathrm{ND}-0.013^{\mathrm{b}}$ \\
ND non detected & 0.02 & 0.011 & All 13 undetected \\
Three of the 14 solidified products had undetected TCLP values \\
Ten of the 15 solidified products had undetected values
\end{tabular}

\subsubsection{Chromium}

The literature generally states that chromium must be reduced from chromium (VI) to chromium (III) prior to any stabilization in order to form the insoluble chromium (III) form of the metal (Wiles and Barth, 1992). Chromium (III) is most insoluble between pH 5 
and 13. The interstitial liquid is commonly within this range during the hydration of a portland cement.

Using DTA, Tashiro et al. (1979) showed that chromium was an accelerator for the aluminate phase, $\mathrm{C}_{3} \mathrm{~A}$. Chromium also increased the total porosity as well as the average diameter of the pores at early stages when ettringite is forming. Tashiro et al. also studied mortar samples containing $5 \% \mathrm{Cr}_{2} \mathrm{O}_{3}$. Compared with the control, the UCS of these samples at 28 days dropped from 203 to $85 \mathrm{~kg} / \mathrm{cm}^{2}$ in the presence of chromium.

The active interaction of chromium was also studied by Brown and Bishop (1985), who came to the conclusion that this species was bound in the silicate matrix of the cement paste. The same conclusion was drawn by Mollah et al. (1992), who incorporated a $10 \mathrm{wt} \%$ chromium solution in portland cements with a water-to-cement-ratio of 0.40 . The results of FTIR analysis led them to think that $\mathrm{Cr}^{3+}$ could be incorporated in the CSH structure, because they thought a substitution of silicon (IV) by chromium (III) was possible. This was also the conclusion of a study made by Heimann et al. (1992): that is, chromium is being substituted in the silicate matrix during CSH formation. They also noticed that chromium was an accelerator and was incorporated in all the hydrates of OPC paste.

Davis and Cocke (1991) prepared two simulated aqueous wastes containing 10 and 20\% $\mathrm{Cr}\left(\mathrm{NO}_{3}\right)_{3}$, based upon the weight of portland cement paste. They measured the porosity of the waste form before and after leaching. They found that the fine porosity increased when chromium was added compared with the control.

Akhter et al. (1990) stabilized a soil contaminated with $12,200 \mathrm{ppm}$ chromium by using combinations of portland cement and various additives. The EP Toxicity leaching test performed on the raw soil obtained $441 \mathrm{ppm}$ chromium in the leachate. After stabilization, none of their tested grout formulations were able to pass the modified EP Toxicity leaching test to achieve less than the regulatory limit of $5 \mathrm{ppm}$ for this metal ion.

The study of Bricka and Cullinane (1990) involved a composite waste containing $1520 \mathrm{mg} / \mathrm{L}$ of chromium. The TCLP on the raw composite waste resulted in a leachate concentration of 
$2.2 \mathrm{mg} / \mathrm{L}$ chromium, while the portland cement-treated waste was $2.1 \mathrm{mg} / \mathrm{L}$. This result showed that portland cement, without additives, is not very effective for the fixation of chromium (IIi).

The need for the reduction of chromium (VI) to chromium (III) is well illustrated by two publications he first one relates to reduction before solidification in portland cement. Jacobs (1992, studied the reduction of chromium by ferrous ammonium sulfate, which, compared with other reductants, is very efficient over a broad range of $\mathrm{pH}$. He studied a waste material containing $6000 \mathrm{mg} / \mathrm{kg}$ of $\mathrm{Cr}^{6+}$ and lowered the concentration, through reduction, to below $100 \mathrm{mg} / \mathrm{kg}$ after using the correct waste loading and waiting 3 days for the reaction to be completed. This concentration of $100 \mathrm{mg} / \mathrm{kg}$ corresponded to the EP Toxicity limit of $5 \mathrm{mg} / \mathrm{L}$ (dilution by a factor of 20 during extraction procedure).

In a second illustration of this effect, Langton (1989) relied upon the reducing capacity of BFS as an alternative to portland cement in a waste form. Langton worked on the saltstone waste form from the Savannah River Plant. The radioactive, alkaline salt solution contained an average of between 230 and $1400 \mathrm{mg} / \mathrm{L}$ of $\mathrm{Cr}^{6}$. The slag-saltstone host was able both to reduce chromium (VI) to chromium (III) and to stabilize chromium at these concentrations, qualifying the waste form as nonhazardous based upon EP Toxicity and TCLP results. The author compared the diffusion coefficient of $\mathrm{CrO}_{4}{ }^{2 \cdot}$ in two matrices. The slag matrix resulted in a coefficient of $4.5 \times 10^{-13} \mathrm{~cm}^{2} / \mathrm{s}$ while the portland cement was $5 \times 10^{-9} \mathrm{~cm}^{2} / \mathrm{s}$. This factor of 10,000 illustrated the lower leachability of a slag waste form due to the lower porosity and permeability developed by such a binder and the reducing capacity of the slag.

Shin et al. (1992) studied two heavy metal sludges containing copper at a concentration of $74 \mathrm{mg}$ per gram of wet sludge and chromium at $27.5 \mathrm{mg} / \mathrm{g}$ of wet sludge. They showed that chromium is a slight set retarder, but it also produced waste forms developing lower UCS than the control. The ability of their waste forms to contain the hazardous species was monitored using the EP Toxicity test with three different types of leaching solutions: $0.1 \mathrm{~N}$ acetic acid solution, distilled water, and seawater. The concentrations of chromium found in the leachates were 0.8 to $7.3 \mathrm{mg} / \mathrm{L}$ in the leachate using acetic acid, $<0.2 \mathrm{mg} / \mathrm{L}$ in distilled water, and $<0.1 \mathrm{mg} / \mathrm{L}$ in seawater. 
A simulated Hanford waste studied by Claghorn et al. (1990) contained 1258 ppm chromium in solution. The authors experimented with the influence of variation of major species present in the waste. They studied 39 different combinations of the waste mixed with BFS, fly ash, and portland cement blend. They measured the concentration of the toxic species present in the leachates of each test. For chromium, they obtained concentrations ranging from 7.6 to $<0.1 \mathrm{ppm}$. Among the 39 combinations, 2 had concentrations of chromium above the $5-\mathrm{mg} / \mathrm{L}$ regulatory limit ( 7.6 and $6.1 \mathrm{ppm}$ ). The other 37 tests were all below 1.7 ppm.

Bricka and Hill (1989) tried different methods for the precipitation of chromium from wastewaters. Other than the traditional metal hydroxide precipitation, they tested starch xanthate and cellulose precipitation. They obtained sludges which contained $19.7 \mathrm{ing}$ of chromium per gram of dry cellulose sludge, $17.6 \mathrm{mg}$ of chromium per gram of dry starch sludge, and $74.9 \mathrm{mg}$ of chromium per gram of hydroxide sludge. The results of EP Toxicity tests on these materials are presented in the following table.

\begin{tabular}{lccc}
\hline & \multicolumn{3}{c}{ Nature of the sludge } \\
\cline { 2 - 4 } & Starch & Cellulose & Hydroxide \\
\hline $\begin{array}{l}\text { Concentration in raw sludge as } \\
\text { milligram of } \mathrm{Cr}^{3+} \text { per gram of dry } \\
\text { sludge }\end{array}$ & 17.6 & 19.7 & 74.9 \\
$\begin{array}{l}\text { Concentration in the leachate of the } \\
\text { raw sludge }(\mathrm{mg} / \mathrm{L})\end{array}$ & 12.66 & 3.385 & 242.0 \\
$\begin{array}{l}\text { Concentration in the leachate of the } \\
\text { solidified sludge }(\mathrm{mg} / \mathrm{l})\end{array}$ & 0.0643 & 0.075 & 0.0138 \\
\hline
\end{tabular}

Jones et al. (1992) studied a synthetic treatment sludge containing $3170 \mathrm{mg}$ chromium per kilogram of dry sludge. The EP Toxicity concentration of chromium in the raw sludge leachate was $242 \mathrm{mg} / \mathrm{L}$. After stabilization in a portland cement-based matrix, the concentration of the leachate fell to $0.010 \mathrm{mg} / \mathrm{L}$.

In a study by Stegemann and Cote (1990), 5 hazardous wastes containing various contaminants were solidified using 15 industrial cement-based processes existing at 
development or commercial stage. The resulting solidified products were studied by five independent laboratories that performed various tests, among them TCLP, to evaluate and compare the performances of these waste forms. Leaching data for chromium are summarized in the following table.

\begin{tabular}{lccc}
\hline Waste ID & $\begin{array}{c}\text { Concentration } \\
\text { in the raw waste } \\
(\mathrm{mg} / \mathrm{kg})\end{array}$ & $\begin{array}{c}\text { TCLP } \\
\text { concentration of } \\
\text { the raw waste } \\
(\mathrm{mg} / \mathrm{L})\end{array}$ & $\begin{array}{c}\text { Range of TCLP } \\
\text { concentration of the } \\
\text { solidified waste }(\mathrm{mg} / \mathrm{L})\end{array}$ \\
\hline WTC solution & 1,600 & 1,600 & $\mathrm{ND}-1.34^{\mathrm{a}}$ \\
WES sludge & 18,000 & 0.02 & $0.012-5.9^{\circ}$ \\
Aluminum sludge & 1,000 & 0.55 & $\mathrm{ND}-4.5^{\mathrm{b}}$ \\
Dredged sediment & 200 & 0.09 & $\mathrm{ND}-0.3^{\mathrm{c}}$ \\
\hline
\end{tabular}

ND = non detected

" Five of 14 solidified products had TCLP below the detection limit.

${ }^{b}$ Eleven of 13 solidified prociucts had TCLP concentration below the detection limit.

${ }^{c}$ Eleven of 15 solidified projucts had TCLP concentration below the detection limit.

\section{2 .5 Nickel}

Nickel has a solubility of only $7 \times 10^{-3} \mathrm{mg} / \mathrm{L}$ when precipitated as the hydroxide and a solubility of $7 \times 10^{-8} \mathrm{mg} / \mathrm{L}$ when precipitated as the sulfide (Grosse, 1991). Conner (1990) stated that this species does not present problems for fixation in cement-based matrices except when complexes are involved. In general, according to Conner, the concentrations of nickel in the leachates of EP Toxicity or TCLP tests are reduced by two or more orders of magnitude following $\mathrm{S} / \mathrm{S}$.

Bricka and Hill (1989) discussed the comparative efficiency of different metal precipitations from wastewaters, that is, starch, cellulose, and hydroxide precipitation. The results of the EP Toxicity leaching tests of these materials are as follows. 


\begin{tabular}{llcc}
\hline & \multicolumn{3}{c}{ Nature of the sludge } \\
\cline { 2 - 4 } & Starch & Cellulose & Hydroxide \\
\hline $\begin{array}{l}\text { Concentration of nickel in the raw sludge } \\
\text { as milligram of nickel per gram of dry } \\
\text { sludge (mg/g) }\end{array}$ & 13.1 & 19.9 & 80.0 \\
$\begin{array}{l}\text { Concentration of nickel in the leachate of } \\
\text { the raw sludge (mg/L) }\end{array}$ & 50.95 & 248.3 & 148.8 \\
$\begin{array}{l}\text { Concentration of nickel in the leachate of } \\
\text { the solidified sludge (mg/L) }\end{array}$ & 0.117 & 0.0038 & 0.0025 \\
\hline
\end{tabular}

Jones et al. (1992) studied a synthetic treatment sludge containing 29,350 mg of nickel per kilogram of dry sludge. This untreated sludge obtained a concentration of nickel in the EP Toxicity leachate of $149 \mathrm{mg} / \mathrm{L}$. When testing a portland cement-based S/S process, they measured a concentration of nickel in the leachates of only $0.083 \mathrm{mg} / \mathrm{L}$.

\subsubsection{Lead}

The amphoteric nature of lead makes it difficult to immobilize in cement-based waste forms. Lead is fairly insoluble as the hydroxide form between $\mathrm{pH} 7$ and 12 . Reductive processes do not yield good results for the retention of lead. Because the $\mathrm{pH}$ of interstitial pore liquid in a cement paste is often above 12 , control of $\mathrm{pH}$ is an important factor in improving lead retention in the waste form (Wiles and Barth,1992).

Lead acts as a retarder for the set of portland cement, an effect demonstrated in many publications. Ortego et al. (1989) used techniques such as TGA and FTIR spectroscopy to observe this phenomenon. They noticed that the retardation effect of lead was, as for zinc, one of the most important among the metals they studied. They think that the mechanism for hydration inhibition is a physical one, due to the formation of insoluble compounds around the silicate phases that prevent access to water, a theory also shared by Thomas et al. (1981).

The fixation of lead, through binding to the silicate matrix of the cement paste, was confirmed by the study of Brown and Bishop (1985). They state that the fixation mechanism 
can explain why the leachability of lead is dependent upon the dissolution of the silicate matrix.

In a study by Davis and Cocke (1991), lead nitrate-based solutions were immobilized at concentrations of 10 and $20 \%$, based upon the weight of cement paste. They monitored the porosity of the waste form before and after leaching. They observed that the porosity of lead-doped cement was above the control for the "capillary" pores. They correlated this observation to the retardation effect of lead on the set of cement.

The effect of adding lead nitrate at 2,5 , and $8 \mathrm{wt} \%$, based upon the weight of cement present in a cement-based matrix, was studied by Cullinane et al. (1987). They measured the UCS developed for these waste forms and compared them with a control sample. The percent change, when compared with the control, was, respectively, $-2 \%$ for $2 \% \mathrm{~Pb},+18 \%$ for $5 \% \mathrm{~Pb}$, and $+10 \%$ for $8 \% \mathrm{~Pb}$.

During the experiment they performed, Claghorn et al. (1990) varied the proportions of the major species in a simulated waste for the Hanford site. In this work, 39 formulations were tested, in which the grout was composed of $47 \mathrm{wt} \% \mathrm{BFS}, 47 \mathrm{wt} \%$ fly ash, and $6 \mathrm{wt} \%$ portland cement combined with the simulated waste. A mixed ratio of $1.1 \mathrm{~kg}$ dry blend per liter of simulated waste was used. This simulated waste had variable concentrations of the major species, but the concentration of lead in the waste was constant at $5.5 \mathrm{ppm}$.

EP Toxicity leach tests results obtained for the 39 combinations ranged from $<0.02$ to $0.1 \mathrm{ppm}$.

Bricka and Cullinane (1990), in their demonstration of S/S as the best demonstrated available technology, studied nine listed wastes, three of which contained lead. They measured UCS and TCLP leachability. The three portland cement-based waste forms produced that contained lead exhibited UCS above the current NRC-required value of $50 \mathrm{psi}$. The results of the TCLP leaching tests are presented in the following table. 
61

\begin{tabular}{cccc}
\hline Waste ID & $\begin{array}{c}\text { Raw composite } \\
\text { concentration } \\
(\mathrm{mg} / \mathrm{L})\end{array}$ & $\begin{array}{c}\text { Raw TCLP } \\
\text { concentration } \\
(\mathrm{mg} / \mathrm{L})\end{array}$ & $\begin{array}{c}\text { TCLP for the } \\
\text { cement-treated } \\
\text { waste }(\mathrm{mg} / \mathrm{L})\end{array}$ \\
\hline $\mathrm{K} 004$ & 666,820 & 1,410 & 0.54 \\
$\mathrm{~K} 061$ & 20,300 & 45.1 & 1.16 \\
$\mathrm{~K} 046$ & 967 & 103 & 0.078 \\
\hline
\end{tabular}

Tashiro et al. (1979) worked on synthetic mixtures of $C_{3} A$ and gypsum to which $5 \%$ by weight lead hydroxide $\left[\mathrm{Pb}_{2} \mathrm{O}(\mathrm{OH})_{2}\right]$ was added. DTA analysis showed a rapid acceleration of the set followed by a pronounced retardation, measured by the liberation of heat produced during the hydration reaction. They examined the sample by SEM and observed that there was no formation of abundant ettringite, as is the case for other heavy metals. The porosity, however, increased, as well as the average diameter of the pores, which shifted toward larger sizes. This observation, that lead did not appear to change the hydrated nature of the cement paste by generating abundant ettringite, was confirmed by Campbell et al. (1987).

Butler et al. (1990) proposed a theory explaining the poor retention of lead from cementbased matrices in leaching tests, compared with other metals such as cadmium. They suggested that when lead is present in a waste as a soluble salt, there are consecutive crystallizations and dissolutions of the lead salts, with these salts being more accessible to the leachate solution. These reactions will also depend upon changes in $\mathrm{pH}$ in the cement pore water. This theory is also advanced by Akhter et al. (1990), who worked with a soil contaminated with $10,900 \mathrm{ppm}$ lead. The EP Toxicity leaching test performed on the soil yielded a concentration in the leachate of $379 \mathrm{ppm}$. This soil was stabilized by adding $11 \%$ slag and $11 \%$ OPC. The waste form produced, had a concentration of $0.28 \mathrm{ppm}$ lead in the leachate of a modified EP Toxicity test.

Some authors have advanced the theory that phosphate can be useful in retaining certain species in cement-based waste forms. Ortego (1990) performed some tests on a waste containing lead nitrate, lead nitrate plus sodium sulfide, and lead nitrate plus sodium phosphate, introduced in the cement paste at $10 \mathrm{wt} \%$. After leaching in seven consecutive solutions of acetic acid, the cumulative weight percent extracted from the waste forms was as 
follows: $11.1 \%$ from the cement alone, $15.01 \%$ from the matrix containing sulfide, and $4.29 \%$ from the matrix containing phosphate.

De Percin (1990) described the performance of three solidification technologies tested at Superfund sites. The wastes at these sites were mixtures of organics and inorganics species such as lead. The Hazcon process was tested on a soil containing up to $2.3 \%$ lead, resulting in a concentration in the TCLP leachate of 20 to $50 \mathrm{mg} / \mathrm{L}$. After treatment, the concentration of lead in the leachate from the stabilized material was below $0.1 \mathrm{mg} / \mathrm{L}$.

The Chemfix technology was tested on both soil and ash matrices containing 18,000 to $117,000 \mathrm{mg} / \mathrm{kg}$ of lead. The TCLP results on the treated waste showed a reduction of 93.5 to $100 \%$, corresponding to a lead concentration in the leachate ranging from $<0.5$ to $46 \mathrm{mg} / \mathrm{L}$.

The last technology tested was Soliditech. The waste contained lead at concentrations ranging from 650 to $2470 \mathrm{mg} / \mathrm{kg}$. The TCLP leachate from the pretreatment filter cake contained $4.3 \mathrm{mg} / \mathrm{L}$ lead, while lead was not detected in the posttreated waste leachate.

In a study by Stegemann and Cote (1990), five hazardous wastes containing various contaminants were solidified using 15 industrial cement-based processes existing at development or commercial stage. The resulting solidified products were studied by five independent laboratories that performed various tests, among them TCLP, to evaluate the performances of these waste forms. Leaching data for lead are summarized in the following table. 


\begin{tabular}{|c|c|c|c|}
\hline Waste ID & $\begin{array}{l}\text { Concentration } \\
\text { in the raw } \\
\text { waste } \\
(\mathrm{mg} / \mathrm{kg})\end{array}$ & $\begin{array}{c}\text { TCLP } \\
\text { concentration of } \\
\text { the raw waste } \\
(\mathrm{mg} / \mathrm{L})\end{array}$ & $\begin{array}{c}\text { Range of TCLP } \\
\text { concentration of the } \\
\text { solidified waste } \\
(\mathrm{mg} / \mathrm{L})\end{array}$ \\
\hline WTC solution & 8100 & 8100 & ND - $4.3^{\star}$ \\
\hline Aluminum sludge & 40 & 0.004 & All 13 undetected \\
\hline Dredged sediment & 150 & $<0.01$ & All 15 undetected \\
\hline Wood waste soil & 70 & $<0.1$ & $N D-0.011^{b}$ \\
\hline
\end{tabular}

\subsubsection{Arsenic}

Arsenic is an element which has amphoteric properties and exists in different valence states. The valence state can change easily and rapidly with the redox potential. Arsenic should be reduced to the more insoluble trivalent or elemental form in order to be more effectively immolibilized in cement-based waste forms. The $\mathrm{pH}$ of the pore water of the waste form must be below 11, because arsenic (III) is soluble at $\mathrm{pH}$ values above 11 (Wiles and Barth, 1992).

In a study in which contaminated soils were immobilized using cement or pozzolanic fixing agents, Akhter et al. had to deal with a concentration of $12,200 \mathrm{ppm}$ arsenic in the waste. Among the different types of admixtures tested, only the one containing 44\% Type I portland cement was able to reduce the concentration of arsenic in the EP Toxicity leachate below the regulatory limit of $5 \mathrm{mg} / \mathrm{L}$, from $420 \mathrm{ppm}$ for the raw soil, to $4.56 \mathrm{ppm}$ for the treated waste form.

In surrogate low-level wastes from the Hanford site prepared by Claghorn et al. (1990), arsenic was present at a constant concentration of $5.5 \mathrm{ppm}$ among 39 variations of major species concentrations in the waste. EP Toxicity leach tests performed on the waste forms resulted in concentrations of arsenic in the range of $<0.008$ to $0.07 \mathrm{ppm}$. 
Alvarez et al. (1990) reported the results of two S/S processes performed at two Superfund sites: Tri State and Synco Resins. Arsenic was present in the contaminated soils at a concentration of $8.12 \mathrm{mg} / \mathrm{kg}$ of soil at Tri State and $581 \mathrm{mg} / \mathrm{kg}$ at Synco Resins. Different S/S systems were evaluated with water-to-total solids ratios of 0.30 to 0.45 and binder-to-soil ratios of $0.50,0.75$, and 1.0. For the portland cement matrix, the results of the TCLP leaching tests performed on the treated waste were below $0.005 \mathrm{mg} / \mathrm{L}$ for Tri-State and 0.016 1. $J .033 \mathrm{mg} / \mathrm{L}$ depending on the formulation used, for Synco Resins.

In a study by Stegemann and Cote (1990), five hazardous wastes containing various contaminants were solidified using 15 industrial processes existing at development or commercial stage. The resulting solidified products were studied by five independent laboratories that performed various tests, among them TCLP, to evaluate the performances of these waste forms. Leaching data for arsenic are summarized in the following table.

\begin{tabular}{lccc}
\hline Waste ID & $\begin{array}{c}\text { Concentration in the } \\
\text { raw waste }(\mathrm{mg} / \mathrm{kg})\end{array}$ & $\begin{array}{c}\text { TCLP concentration } \\
\text { of the raw waste } \\
(\mathrm{mg} / \mathrm{L})\end{array}$ & $\begin{array}{c}\text { Range of TCLP } \\
\text { concentration of the } \\
\text { solidified waste }(\mathrm{mg} / \mathrm{L})\end{array}$ \\
\hline WTC solution & 2400 & 2400 & $0.009-36.4^{\circ}$ \\
Aluminum sludge & 10 & 0.001 & $\mathrm{ND}-0.0017^{\mathrm{b}}$ \\
Wood waste soil & 70 & 0.0045 & $\mathrm{ND}-0.031^{\mathrm{c}}$ \\
ND non detected \\
"Forteen solidified products were tested. \\
"Twelve of 13 solidified products had TCLP concentrations below the detection limit. \\
'Eleven of 13 solidified products had TCLP concentrations below the detection limit.
\end{tabular}

\subsubsection{Copper}

Copper acts as a retarder for cement hydration. However, it is not known to present major problems during or after fixation in cement-based waste forms. Very few data related to work on this element are available from the literature.

Shin et al. (1992) tried to optimize a mixture design for the disposal of solidified, heavy metal sludges. One of the constituents of these sludges was copper, at a concentration of $74 \mathrm{mg}$ per gram of wet sludge. They observed an inhibition of the hydration of cement in the presence 
of copper. The measured set time of the control sample was $8 \mathrm{~h}$, while the waste-form set times were between 40 and $70 \mathrm{~h}$, depending upon the ratio of portland cement to sludge used. The measured UCS for the control sample was $270 \mathrm{psi}$, and the range for the waste forms was $180---340$ psi.

Shin et al. also leached selected waste forms in three types of leachants: $0.1 \mathrm{~N}$ acetic acid solution, distilled water, and seawater. They measured the copper concentration in the leachates and obtained 90 to $770 \mathrm{mg} / \mathrm{L}$ in acetic acid solution, 0.2 to $0.5 \mathrm{mg} / \mathrm{L}$ in distilled water, and 0.05 to $0.15 \mathrm{mg} / \mathrm{L}$ in seawater.

Cne of the five wastes presented in the study of Stegeman and Cote (1990) contained copper as a pollutant, at a concentration of $70 \mathrm{mg} / \mathrm{kg}$ in a dredged sediment. The TCLP test performed on the raw waste revealed a concentration of $0.019 \mathrm{mg} / \mathrm{L}$. Fifteen industrial proprietary solidification processes were tested with this waste. The TCLP concentrations of the solidified products ranged from 0.079 to $0.79 \mathrm{mg} / \mathrm{L}$, with three samples being below the detection limit.

\subsubsection{Other RCRA Metals: Barium, Selenium, and Silver}

Barium has a chemistry resembling that of calcium. Therefore, its incorporation in cementbased waste forms is not expected to present a problem when considering cement hydration chemistry and mechanisms. When this species is leached from the cement-based matrix, its release follows a diffusion mechanism (Roy, 1986). This species is itself a trace component of portland cement and can be substituted in the silicate phase for calcium. The barium sulfate salt is very insoluble, only $2.22 \mathrm{mg} / \mathrm{L}$ in cold water (CRC Handbook, 1992). For those waste streams that are extremely rich in barium, and where the leachability of this species is above the RCRA TCLP-regulated limit of $100 \mathrm{mg} / \mathrm{L}$, a pretreatment step to precipitate the barium as barium sulfate is necessary and can involve simply adding the proper amount of soluble sulfate salt. 
Selenium is not very often found in waste streams, and when it is present, its concentration in leachates is usually found to be well below the EPA TCLP regulatory limit of $1.0 \mathrm{mg} / \mathrm{L}$. No treatment process appears to exist for this element.

Silver nitrate and silver halides are the most common species found in association with this element. Silver chloride is fairly insoluble, with a solubility of only $0.89 \mathrm{mg} / \mathrm{L}$ in cold water (CRC Handbook, 1992). Silver does not usually present a problem for fixation in cementbased waste forms. However, if waste streams are loaded with high concentrations of silver, a treatment to form insoluble silver chloride can be employed, or the $\mathrm{pH}$ can be raised to form insoluble silver oxide $\left(\mathrm{Ag}_{2} \mathrm{O}\right)$.

A study by Claghorn et al. (1990), who worked with a surrogate waste from the Hanford site, illustrates the fixation of some of these species in cement-based waste forms. The grout preparation was performed by mixing $1.1 \mathrm{~kg}$ dry blend additives with $1 \mathrm{~L}$ of surrogate waste solution. Their surrogate waste contained $110 \mathrm{ppm}$ barium, $1.1 \mathrm{ppm}$ selenium, and $5.5 \mathrm{ppm}$ silver in solution. The concentrations of these species in the leachates of their EP Toxicity tests were $<0.2$ to $1.9 \mathrm{ppm}$ for barium, $<0.02 \mathrm{ppm}$ for selenium, and $<0.02$ to $0.03 \mathrm{ppm}$ for silver.

Another example of the fixation of a mixture of hazardous metals is discussed in a paper by Alvarez et al. (1990), who reported in their work the results of treatability studies performed for two actual Superfund sites: Tri State metal plating site at Columbus, Indiana, and Synco Resins site at Keatney, New Jersey. A water-to-total solid ratio of 0.30 to 0.45 was used as well as a binder-to-soil ratio of $0.50,0.75$ and 1.0 . The ability of their cement-based waste forms to reduce the mobility of a number of hazardous waste metals is illustrated in the following table, based upon work for the Tri State site. 
67

\begin{tabular}{lccc}
\hline Waste species & $\begin{array}{c}\text { Soil concentration } \\
(\mathrm{mg} / \mathrm{kg})\end{array}$ & $\begin{array}{c}\text { TCLP, untreated } \\
\text { soil }(\mathrm{mg} / \mathrm{L})\end{array}$ & $\begin{array}{c}\text { TCLP, treated soil } \\
(\mathrm{mg} / \mathrm{L})\end{array}$ \\
\hline Arsenic & 8.12 & $<0.005$ & $<0.005$ \\
Barium & 44.4 & 1.016 & 0.845 \\
Cadmium & 49.9 & 1.273 & $<0.005$ \\
Chromium & 506 & 0.687 & 0.267 \\
Copper & 99.2 & 0.063 & 0.080 \\
Lead & 267 & 0.100 & 0.036 \\
Mercury & $<0.12$ & ND & ND \\
Nickel & 159 & 0.512 & 0.045 \\
Selenium & ND & ND & ND \\
Silver & ND & ND & ND \\
Thallium & ND & ND & ND \\
Vanadium & 128 & ND & ND \\
Zinc & 79.0 & 0.337 & 0.036 \\
\hline
\end{tabular}

ND = not detected.

In addition to these TCLP results, similar results are available and are presented in the following table for the Synco Resins site TCLP tests. 


\begin{tabular}{lccc}
\hline Waste species & $\begin{array}{c}\text { Soil concentration } \\
(\mathrm{mg} / \mathrm{kg})\end{array}$ & $\begin{array}{c}\text { TCLP, untreated } \\
\text { soil }(\mathrm{mg} / \mathrm{L})\end{array}$ & $\begin{array}{c}\text { TCLP, treated } \\
\text { soil }(\mathrm{mg} / \mathrm{L})\end{array}$ \\
\hline Arsenic & 581 & 1.007 & 0.033 \\
Barium & 166 & 1.007 & 1.847 \\
Cadmium & 1.29 & 0.006 & $<0.005$ \\
Chromium & 65.3 & 0.014 & 0.016 \\
Copper & 91.5 & 0.116 & 0.194 \\
Lead & 224 & 0.092 & $<0.008$ \\
Mercury & 0.75 & ND & ND \\
Nickel & 20.7 & 0.052 & 0.045 \\
Selenium & ND & ND & ND \\
Silver & 0.74 & ND & ND \\
Thallium & ND & ND & ND \\
Vanadium & 42.2 & 0.8 & $<0.010$ \\
Zinc & 167 & 1.07 & 0.061 \\
\hline
\end{tabular}

ND = not detected.

Table 2 presents data concerning metallic waste species that can potentially interfere with cement-based $\mathrm{S} / \mathrm{S}$ processes. The table, a summary of the experiences of many researchers, shows the expected levels of sensitivity of the various species to produce the observed effects.

\subsection{OTHER SPECIES}

\subsubsection{Calcium and Magnesium}

Calcium and magnesium cations, when present in aqueous solutions, act to accelerate the set of cement and promote hardening (Taylor, 1990; Lea, 1971). This is because the saturation of cement pore solution with respect to calcium is achieved more quickly, and crystal growth is therefore promoted, with magnesium substituting for calcium to form its hydroxide. 
Table 2 Summary data of metallic waste species

\begin{tabular}{|c|c|c|c|}
\hline Species & Concentrations employed * & Observed efiect" & Reference " \\
\hline \multirow[t]{3}{*}{ Aluminum } & $\bullet 0.783 \mathrm{M} \mathrm{AlO}_{2}$ solution & & Claghorn et al., 1990 \\
\hline & $\bullet 0.421 \mathrm{M} \mathrm{AlO}_{2}$ solution & & Spence et al., 1993 \\
\hline & $\begin{array}{l}\bullet[A]] \text { metallic form }=0.005 \text { to } 0.2 \mathrm{wt} \% / \\
\text { cement }\end{array}$ & Hydrolysis & Troxell et al, 1968 \\
\hline \multirow[t]{4}{*}{ Arsenic } & -[As] $=12,200 \mathrm{ppm} /$ soil & EP tox: $4.56 \mathrm{ppm}$ & Akhter et al., 1990 \\
\hline & -[As] $=5.5 \mathrm{ppm}$ solution & TCLP: $<0.008$ to $0.07 \mathrm{ppm}$ & Claghorn et al, 1990 \\
\hline & $\begin{array}{l}\bullet[\mathrm{As}]=8.12 \mathrm{mg} / \mathrm{kg} / \text { soil } \\
\bullet[\mathrm{As}]=581 \mathrm{mg} / \mathrm{kg} / \text { soil }\end{array}$ & $\begin{array}{l}\text { TCLP: }<0.005 \mathrm{mg} / \mathrm{L} \\
\text { TCLP: } 0.033 \mathrm{mg} / \mathrm{L}\end{array}$ & Alvarez et al, 1990 \\
\hline & $\begin{array}{l}\text { [As] }=2400 \mathrm{mg} / \mathrm{kg} \text { synthetic solution } \\
\odot[A s]=10 \mathrm{mg} / \mathrm{kg} / \text { sludge } \\
\text { ๑As] }=70 \mathrm{mg} / \mathrm{kg} / \text { soil }\end{array}$ & $\begin{array}{l}\text { TCLP: } 0.009 \text { to } 36.4 \mathrm{mg} / \mathrm{L} \\
\text { TCLP: }<0.002 \mathrm{mg} / \mathrm{L} \\
\text { TCLP: }<0.03 \mathrm{mg} / \mathrm{L}\end{array}$ & Stegemann and Cote, 1990 \\
\hline \multirow[t]{2}{*}{ Barium } & $\bullet[\mathrm{Ba}]=110 \mathrm{ppm}$ solution & EP tox: $<0.2$ to $1.9 \mathrm{ppm}$ & Claghorn et al., 1990 \\
\hline & $\begin{array}{l}\bullet[\mathrm{Ba}]=44.4 \mathrm{mg} / \mathrm{kg} / \mathrm{soil} \\
\bullet[\mathrm{Ba}]=166 \mathrm{mg} / \mathrm{kg} / \text { soil }\end{array}$ & $\begin{array}{l}\text { TCLP: } 0.85 \mathrm{mg} / \mathrm{L} \\
\text { TCLP: } 1.85 \mathrm{mg} / \mathrm{L}\end{array}$ & Alvarez et al., 1990 \\
\hline \multirow[t]{6}{*}{ Cadmium } & $-\left[\mathrm{Cd}\left(\mathrm{NO}_{3}\right)_{2}\right]=10 \mathrm{wt} \% /$ cement waste form & $21.95 \%$ released at 7 days & Ortego, 1990 \\
\hline & $\bullet\left[\mathrm{Cd}\left(\mathrm{NO}_{3}\right)_{2}\right]=2000 \mathrm{ppm}$ solution & $0.01 \mathrm{ppm}$ released & Poon and Perry, 1987 \\
\hline & $\bullet[\mathrm{Cd}]=2.2$ to $27 \mathrm{~g} / \mathrm{kg}$ cement paste & $<0.1$ ppm leached & Heimann et al, 1992 \\
\hline & $\bullet[\mathrm{Cd}]=10,000 \mathrm{ppm} /$ soil & $0.48 \mathrm{ppm}$ leached & Akhter et al, 1990 \\
\hline & $\begin{array}{l}\bullet[C d]=4600 \mathrm{mg} / \mathrm{kg} / \text { solution } \\
\bullet[C d]=4000 \mathrm{mg} / \mathrm{kg} / \text { sludge }\end{array}$ & $\begin{array}{l}\text { TCLP: undetected to } 31.5 \mathrm{mg} / \mathrm{L} \\
\text { TCLP: } \leq 0.09 \mathrm{mg} /\end{array}$ & Stegemann and Cote, 1990 \\
\hline & $\begin{array}{l}\bullet[\mathrm{Cd}]=19.9 \mathrm{mg} / \mathrm{g} / \text { dry cellulose sludge } \\
\bullet[\mathrm{Cd}]=33.3 \mathrm{mg} / \mathrm{g} / \text { dry starch sludge } \\
\bullet[\mathrm{Cd}]=16.4 \mathrm{mg} / \mathrm{g} / \text { dry hydroxide sludge }\end{array}$ & $\begin{array}{l}\text { EP tox: }<0.0001 \mathrm{mg} / \mathrm{L} \\
\text { EP tox: }<0.0001 \mathrm{mg} / \mathrm{L} \\
\text { EP tox: }<0.0001 \mathrm{mg} / \mathrm{L}\end{array}$ & Bricka and Hill, 1989 \\
\hline
\end{tabular}


Table 2 (continued)

\begin{tabular}{|c|c|c|c|}
\hline Species & Concentrations employed " & Observed effect & Refierenoce \\
\hline \multirow[t]{2}{*}{ Cadmium } & $\bullet[\mathrm{Cd}]=35.4 \mathrm{mg} / \mathrm{kg} /$ sediment & $<0.003 \mathrm{mg} / \mathrm{kg}$ leached & Myers and Zappi, 1992 \\
\hline & $\bullet[\mathrm{Cd}]=6330 \mathrm{mg} / \mathrm{kg} / \mathrm{dry}$ sludge & EP tox: $0.0021 \mathrm{mg} / \mathrm{L}$ & Jones et al., 1992 \\
\hline \multirow[t]{13}{*}{ Chromium } & $\bullet\left[\mathrm{Cr}_{2} \mathrm{O}_{3}\right]=5 \mathrm{wt} \% /$ cement mortar & $\begin{array}{l}\text { Accelerator for } \mathrm{C}_{3} \mathrm{~A} \\
\text { Decrease of UCS }\end{array}$ & Tashiro et al., 1979 \\
\hline & $\bullet[\mathrm{Cr}]=10 \%$ solution & Accelerator & Mollah et al., 1992 \\
\hline & $\bullet\left[\mathrm{Cr}\left(\mathrm{NO}_{3}\right)_{3}\right]=10$ and 20 wt \% solution & Increase of fine porosity & Davis and Cocke., 1991 \\
\hline & $\bullet[\mathrm{Cr}]=12,200 \mathrm{ppm} /$ soil & Failed EP toxicity & Akhter et al., 1990 \\
\hline & $\bullet[\mathrm{Cr}]=1520 \mathrm{mg} / \mathrm{L}$ solution & TCLP: $2.1 \mathrm{mg} / \mathrm{L}$ & Bricka and Cullinane, 1990 \\
\hline & $\bullet\left[\mathrm{Cr}^{6+}\right]=6000 \mathrm{mg} / \mathrm{kg}$ & EP tox: $<5 \mathrm{mg} / \mathrm{L}$ & Jacobs, 1992 \\
\hline & $\bullet\left[\mathrm{Cr}^{6+}\right]=230$ to $1400 \mathrm{mg} / \mathrm{L}$ solution & EP tox passed & Langton, 1989 \\
\hline & $\bullet[\mathrm{Cr}]=27.5 \mathrm{mg} / \mathrm{g}$ of wet sludge & $\begin{array}{l}\text { Slight retarder, decrease of UCS } \\
<0.1 \text { to } 7.3 \mathrm{mg} / \mathrm{L} \text { leached }\end{array}$ & Shin et al, 1992 \\
\hline & $-[\mathrm{Cr}]=1258 \mathrm{ppm}$ solution & TCLP: $<0.1$ to $7.6 \mathrm{ppm}$ & Claghorn et al., 1990 \\
\hline & $\begin{array}{l}\bullet[\mathrm{Cr}]=1600 \mathrm{mg} / \mathrm{kg} \text { solution } \\
\bullet[\mathrm{Cr}]=18,000 \mathrm{mg} / \mathrm{kg} / \text { sludge } \\
\bullet[\mathrm{Cr}]=1000 \mathrm{mg} / \mathrm{kg} / \text { sludge } \\
\bullet[\mathrm{Cr}]=200 \mathrm{mg} / \mathrm{kg} / \text { sediment }\end{array}$ & $\begin{array}{l}\text { TCLP: undetected to } 1.34 \mathrm{mg} / \mathrm{L} \\
\text { TCLP: } 0.012 \text { to } 5.9 \mathrm{mg} / \\
\text { TCLP: undetected to } 4.5 \mathrm{mg} / \mathrm{L} \\
\text { TCLP: undetected to } 0.3 \mathrm{mg} / \mathrm{L}\end{array}$ & Stegemann and Cote, 1990 \\
\hline & $\begin{array}{l}\bullet[\mathrm{Cr}]=17.6 \mathrm{mg} / \mathrm{g} \text { of dry starch sludge } \\
\bullet[\mathrm{Cr}]=19.7 \mathrm{mg} / \mathrm{g} \text { of cellulose sludge } \\
\bullet[\mathrm{Cr}]=79.4 \mathrm{mg} / \mathrm{g} \text { of hydroxide sludge }\end{array}$ & $\begin{array}{l}\text { EP tox: } 0.064 \mathrm{mg} / \mathrm{L} \\
\text { EP tox: } 0.075 \mathrm{mg} / \mathrm{L} \\
\text { EP tox: } 0.014 \mathrm{mg} / \mathrm{L}\end{array}$ & Bricka and Hill, 1989 \\
\hline & $\bullet[\mathrm{Cr}\}=754 \mathrm{mg} / \mathrm{kg}$ of sediment & 1.13 to $2.47 \mathrm{mg} / \mathrm{kg}$ leached & Myers and Zappi, 1992 \\
\hline & $\bullet[\mathrm{Cr}]=3170 \mathrm{mg} / \mathrm{kg}$ of dry sludge & EP tox: $0.010 \mathrm{mg} / \mathrm{L}$ & Jones et al., 1992 \\
\hline
\end{tabular}


Table 2 (continued)

\begin{tabular}{|c|c|c|c|}
\hline Species & Concentrations employed " & Observed effect & Reference $^{c}$ \\
\hline \multirow[t]{3}{*}{ Copper } & $\begin{array}{l}\bullet[\mathrm{Cu}]=74 \mathrm{mg} / \mathrm{g} \text { of wet sludge } \\
\bullet[\mathrm{Cu}]=99.2 \mathrm{mg} / \mathrm{kg} / \text { soil } \\
\bullet[\mathrm{Cu}]=91.5 \mathrm{mg} / \mathrm{kg} / \text { soil }\end{array}$ & $\begin{array}{l}\text { Retarder } \\
\text { TCLP: } 0.08 \mathrm{mg} / \mathrm{L} \\
\text { TCLP: } 0.19 \mathrm{mgl}\end{array}$ & $\begin{array}{l}\text { Shin et al., } 1992 \\
\text { Alvarez et al., } 1990\end{array}$ \\
\hline & $\bullet[\mathrm{Cu}]=1730 \mathrm{mg} / \mathrm{kg} /$ sediment & 77.6 to $87.8 \mathrm{mg} / \mathrm{kg}$ leached & Myers and Zappi, 1992 \\
\hline & $\bullet[\mathrm{Cu}]=70 \mathrm{mg} / \mathrm{kg} /$ sediment & TCLP: undetected to $0.79 \mathrm{mg} / \mathrm{L}$ & Stegemann and Cote, 1990 \\
\hline \multirow[t]{9}{*}{ Lead } & $-\left[\mathrm{Pb}\left(\mathrm{NO}_{3}\right)_{2}\right]=10$ and $20 \mathrm{wt} \% /$ cement paste & Retarder, increase of porosity & Davis and Cocke, 1991 \\
\hline & $\begin{array}{l}\bullet\left[\mathrm{Pb}\left(\mathrm{NO}_{3}\right)_{2}\right]=2 \text { wt } \% / \text { cement } \\
-\left[\mathrm{Pb}\left(\mathrm{NO}_{3}\right)_{2}\right]=5 \text { to } 8 \text { wt \% / cement }\end{array}$ & $\begin{array}{l}\text { Slight decrease of UCS } \\
\text { Increase of UCS }\end{array}$ & Cullinane et al., 1987 \\
\hline & $\bullet[\mathrm{Pb}]=5.5 \mathrm{ppm}$ solution & EP tox: $<0.02$ to $0.1 \mathrm{ppm}$ & Claghorn et al., 1990 \\
\hline & $\begin{array}{l}\bullet[\mathrm{Pb}]=666,820 \mathrm{mg} / \mathrm{L} / \text { raw composite } \\
\bullet[\mathrm{Pb}]=20,300 \mathrm{mg} / \mathrm{L} / \text { raw composite } \\
\bullet[\mathrm{Pb}]=967 \mathrm{mg} / \text { raw composite }\end{array}$ & $\begin{array}{l}\text { TCLP: } 0.54 \mathrm{mg} / \mathrm{L} \\
\text { TCLP: } 1.16 \mathrm{mg} / \mathrm{L} \\
\text { TCLP: } 0.08 \mathrm{mg} / \mathrm{L}\end{array}$ & Bricka and Cullinane, 1990 \\
\hline & $\bullet[\mathrm{Pb}]=10,900 \mathrm{ppm} /$ soil & EP tox: $0.28 \mathrm{ppm}$ & Akhter et al., 1990 \\
\hline & $\begin{array}{l}\bullet[\mathrm{Pb}]=8100 \mathrm{mg} / \mathrm{kg} \text { solution } \\
\bullet[\mathrm{Pb}]=40 \mathrm{mg} / \mathrm{kg} / \text { sludge } \\
\bullet[\mathrm{Pb}]=150 \mathrm{mg} / \mathrm{kg} / \text { sedinent } \\
\bullet[\mathrm{Pb}]=70 \mathrm{mg} / \mathrm{kg} / \text { soil }\end{array}$ & $\begin{array}{l}\text { TCLP: undetected to } 4.3 \mathrm{mg} / \mathrm{L} \\
\text { TCLP: undetected } \\
\text { TCLP: undetected } \\
\text { TCLP: undetected to } 0.011 \mathrm{~m} g / \mathrm{L}\end{array}$ & Stegemann and Cote, 1990 \\
\hline & $-\left[\mathrm{Pb}\left(\mathrm{NO}_{3}\right)_{2}\right]=10 \mathrm{wt} \% /$ cement & Fraction released: 4.3 to $15.0 \%$ & Ortego, 1990 \\
\hline & $\begin{array}{l}\bullet[\mathrm{Pb}]=0 \text { to } 2.3 \mathrm{wt} \% / \text { soil } \\
\bullet[\mathrm{Pb}]=18 \text { to } 117 \mathrm{~g} / \mathrm{kg} / \text { soil } \\
\bullet[\mathrm{Pb}]=650 \text { to } 2470 \mathrm{mg} / \mathrm{kg} / \text { soil }\end{array}$ & $\begin{array}{l}\text { TCLP: }<0.1 \mathrm{mg} / \mathrm{L} \\
\text { TCLP: }<0.5 \text { to } 46 \mathrm{mg} / \mathrm{L} \\
\text { TCLP: not detected }\end{array}$ & De Percin, 1990 \\
\hline & $\bullet[\mathrm{Pb}]=2013 \mathrm{mg} / \mathrm{kg} /$ sediment & $0.72 \mathrm{mg} / \mathrm{kg}$ leached & Myers and Zappi, 1992 \\
\hline
\end{tabular}




\section{Species}

Concentrations employed *
Observed efiect "

Reference ${ }^{c}$

Mercury $\quad\left[\mathrm{Hg}\left(\mathrm{NO}_{3}\right)_{2}\right]=10 \mathrm{wt} \%$ solution

- $\left[\mathrm{HgCl}_{2}\right]=0.2 \%$ solution

- $\left[\mathrm{Hg}\left(\mathrm{NO}_{3}\right)_{2}\right]=0.2 \%$ solution

- $\left[\mathrm{HgCl}_{2}\right]=2 \%$ solution

- $\left[\mathrm{Hg}\left(\mathrm{NO}_{3}\right)_{2}\right]=3 \%$ solution

[Hg] $=2 \%$ solution

- $[\mathrm{Hg}]=25,900 \mathrm{mg} / \mathrm{L} /$ raw waste

- $[\mathrm{Hg}]=1.15 \mathrm{mg} / \mathrm{g} /$ dry starch sludge

- $[\mathrm{Hg}]=0.64 \mathrm{mg} / \mathrm{g}$ ! dry cellulose sludge

- $[\mathrm{Hg}]=0.97 \mathrm{mg} / \mathrm{g} / \mathrm{dry}$ cellulose sludge

- $[\mathrm{Hg}]=44 \mathrm{mg} / \mathrm{kg} / \mathrm{dry}$ sludge

- $[\mathrm{Hg}]=200 \mathrm{mg} / \mathrm{kg}$ solution

$\ominus[\mathrm{Hg}]=0.7 \mathrm{mg} / \mathrm{kg} /$ sediment

$\bullet[\mathrm{Hg}]=0.02 \mathrm{mg} / \mathrm{kg} / \mathrm{soill}$

Nickel

-[Ni] $=13.1 \mathrm{mg} / \mathrm{g} / \mathrm{dry}$ starch sludge

$\varphi[\mathrm{Ni}]=19.9 \mathrm{mg} / \mathrm{g} / \mathrm{dry}$ cellulose sludge

- $[\mathrm{Ni}]=80.0 \mathrm{mg} / \mathrm{g} / \mathrm{dry}$ hydroxide sludg

-[Ni] $=29,350 \mathrm{mg} / \mathrm{kg} / \mathrm{dry}$ sludge

- $[\mathrm{Ni}]=122 \mathrm{mg} / \mathrm{kg} /$ sediment

- $[\mathrm{Ni}]=19,000 \mathrm{mg} / \mathrm{kg} / \mathrm{sludge}$

Silver
Retarder

1.2 to 5.4 ppm leached

$0.7 \mathrm{ppm}$ leached

Increase of UCS

Increase of UCS

131 fpm leached

TCLP $28.6 \mathrm{mg} / \mathrm{L}$

EP tox: $<0.008 \mathrm{mg} / \mathrm{L}$

EP tox: $0.002 \mathrm{mg} / \mathrm{L}$

EP tox: $0.562 \mathrm{mg} / \mathrm{L}$

EP tox: $0.95 \mathrm{mg} / \mathrm{L}$

LP: undetected to $3.1 \mathrm{mg} / \mathrm{L}$

LP: undetected to $0.013 \mathrm{mg} / \mathrm{L}$

CLP: undetected

EP tox: $0.015 \mathrm{mg} / \mathrm{L}$

EP tox: $0.004 \mathrm{mg} / \mathrm{L}$

EP tox: $0.002 \mathrm{mg} / \mathrm{L}$

EP tox: $0.083 \mathrm{mg} / \mathrm{L}$

5.5 to $8.9 \mathrm{mg} / \mathrm{kg}$ leached

TCLP: undetected to $0.34 \mathrm{mg} / \mathrm{L}$

EP tox: $<0.02$ to 0.03 ppm

TCLP: Not detected
Bricka and Hill, 1989
McWhinney et al., 1990

Poon and Perry, 1987

Poon and Perry, 1987

Clark et al., 1985

Bricka and Cullinane, 1990

Bricka and Hill, 1989

Jones et al., 1992

Stegemann and Cote, 1990

Jones et al., 1992

Myers and Zappi, 1992

Stegemann and Cote, 1990

Claghorn et al., 1990

Alvarez et al., 1990 
Table 2 (continued)

\begin{tabular}{|c|c|c|c|}
\hline Species & Concentrations employed " & Observed effect & Reference $^{c}$ \\
\hline \multirow[t]{7}{*}{ Zinc } & $\begin{array}{l}\bullet[\mathrm{Zn}] \text { metallic form }=0.005 \text { to } 0.2 \% / \text { cement } \\
\bullet[\mathrm{Zn}]=5 \mathrm{wt} \% / \text { cement and: } \\
{\left[\mathrm{SO}_{3}\right] \text { in cement }<2.5 \%} \\
2.5 \%<\left[\mathrm{SO}_{3}\right] \text { in cement }<5 \% \\
{\left[\mathrm{SO}_{3}\right] \text { in cement }>5.5 \%}\end{array}$ & $\begin{array}{l}\text { Hydrolysis } \\
\text { Accelerator } \\
\text { Retarder } \\
\text { Inhibition of the set }\end{array}$ & $\begin{array}{l}\text { Troxell et al., } 1968 \\
\text { Arliguie and Grandet, } 1990\end{array}$ \\
\hline & $\bullet[\mathrm{Zn}]=900 \mathrm{mg} / \mathrm{kg} /$ sediment & TCLP: undetected to $19.7 \mathrm{mg} / \mathrm{L}$ & Stegemann and Cote, 1990 \\
\hline & $\begin{array}{l}\bullet\left[\mathrm{Zn}\left(\mathrm{NO}_{3}\right)_{2}\right]=2 \mathrm{wt} \% / \text { waste form } \\
\bullet\left[\mathrm{Zn}\left(\mathrm{NO}_{3}\right)_{2}\right]=5 \text { and } 8 \mathrm{wt} \% / \text { waste form }\end{array}$ & $\begin{array}{l}\text { Slight increase of UCS } \\
\text { Decrease of UCS }\end{array}$ & Cullinane et al., 1987 \\
\hline & $\bullet[\mathrm{ZnO}]=5 \mathrm{wt} \% /$ cement mortar & Decrease of UCS & Tashiro et al., 1979 \\
\hline & $\ominus[\mathrm{Zn}]=0.2 \%$ solution & 0.32 to $1.8 \mathrm{ppm}$ leached & Poon et al., 1985,1986 \\
\hline & $-[\mathrm{Zn}]=2.61 \mathrm{mg} / \mathrm{L}$ solution & TCLP: $0.02 \mathrm{mg} / \mathrm{L}$ & Bricka and Cullinane, 1990 \\
\hline & $\bullet[\mathrm{Zn}]=3,017 \mathrm{mg} / \mathrm{kg} /$ sediment & 0.88 to $1.44 \mathrm{mg} / \mathrm{kg}$ leached & Myers and Zappi, 1992 \\
\hline
\end{tabular}

- A solidus or slash (I) preceded and followed by a space is used to indicate based upon the weight of."

- EP = Ertraction Procedure; TCLP = Toricity Characteristic Leaching Procedure; UCS = unconfined compressive strength

- Complete citations are included in the reference section of this report. 
If present in their solid oxide forms, however, calcium and magnesium can present a problem during the hydration of cement. These compounds will be transformed into their hydroxides (slaked) upon reacting with water. This reaction, because it is very exothermic, can present a danger if these oxides are present in large amounts in a dry waste strear...

In addition to the exothermic reaction, there is an expansion in the size cf these compounds upon passing from the oxide to the hydroxide form. If this transformation is slow and does not finish before the end of the set, there is a possibility of severe cracking of the waste form after the set. This problem is encountered in the cement industry during the manufacturing of clinker, and for this reason, the amounts of free $\mathrm{CaO}$ and $\mathrm{MgO}$ present in cements are closely regulated.

\subsubsection{Iron, Manganese, and Titanium}

All of these metals are actually present in portland cement in various amounts. Their concentrations in cement range from 2 to $3 \%$ as $\mathrm{Fe}_{2} \mathrm{O}_{3}$, from 0.16 to $1 \%$ as $\mathrm{Mn}_{2} \mathrm{O}_{3}$, and from 0.1 to $0.46 \%$ as $\mathrm{TiO}_{2}$. The ions of these metals present in a waste stream can substitute in cement hydrates for $\mathrm{Si}^{4+}$ or calcium ions. Data on these metals from the literature are very limited; however, Lea (1971) reports that iron oxide accelerates the initial set, and Conner (1990) states that iron and manganese are well fixed in cement-based waste forms.

Metallic iron may corrode and form oxide, which may increase in volume up to $300 \%$ compared with the metal, and generate stress resulting in degradation of the waste form by formation of cracks. Metallic iron is passivated at the $\mathrm{pH}$ of cement pastes; however, halides promote corrosion at this $\mathrm{pH}$, and corrosion proceeds at lower $\mathrm{pHs}$, which may exist in some waste forms or upon carbonation or leaching of cement paste (Walton et al., 1990). The passivation is related to the formation of a three-dimensional nonporous surface layer. The same is true for manganese upon oxidation (corrosion) to oxide (but to a lesser extent), while titanium metal is not easily oxidized. 


\subsubsection{Thallium, Antimony, Beryllium, Vanadium, and Molybdenum}

These metals belong to a list of species regulated by state and federal governement that are not known to interfere with the set or quality of cement-based waste forms. Analyses are now often performed for some of these species in wastewaters or in the TCLP leachate. No data are available in the literature on thallium and these other metals (Conner, 1990). Beryllium is used in the manufacturing of neutron deflectors in nuclear devices and, therefore, is more likely to be found in areas near federal weapons facilities.

One of the five wastes presented in the study of Stegeman and Cote (1990) contained thallium at a concentration of $20 \mathrm{mg} / \mathrm{kg}$ in an aluminum coil plating sludge. The TCLP test performed on the raw material exhibited a concentration under $0.05 \mathrm{mg} / \mathrm{L}$. Thirteen industrial proprietary solidification processes were tested with this waste, and thallium was undetected in the TCLP leachates from all waste forms produced.

\subsubsection{Aluminum}

Aluminum oxide acts as a set accelerator (Lea, 1971) for cement. Aluminum in alkaline aqueous waste solutions is usually in the form of the aluminate anion $\left(\mathrm{AlO}_{2}^{-}\right)$, which will also accelerate the set of cement, especially when BFS or fly ash is present, for they are activated by this waste anion. At Hanford, a study by Lokken (1992a; 1992b) using simulated waste solutions representing tanks such as 106-AN showed that problems with excessive heat generation were due to the presence of aluminate. Aluminate, present in the Hanford tanks at a concentration of 0.8 to $1 M$, accelerated the set rate, resulting in the centerline grout temperature exceeding Hanford's thermal limit.

Two studies (Claghorn, 1990; Spence et al., 1993) using similar waste solutions containing 0.78 and $0.42 M$ aluminate to represent Hanford wastes were performed without problems by adjusting the grout formulation. This adjustment included use of additives to lower the amount of active slag or ash and/or adding an inert material such as limestone flour (Lokken, 1992a; Lokken, 1992b). 
Aluminate in solution can be pretreated by lowing the $\mathrm{pH}$ of the solution to approximately 6 to 7 , thereby precipitating aluminum hydroxide. Lokken states that the choice of acid used to lower the $\mathrm{pH}$ appears to be important (some being more effective than others), probably due to anion stabilization of aluminum in solution.

Metallic aluminum can cause gas generation problems if present in alkaline cement or grout, due to the formation of hydrogen gas. Troxell et al. (1968) reported using powdered aluminum to form low-strength, porous cement with a low density, using only 0.005 to $0.02 \%$ aluminum, based upon the weight of cement.

\subsubsection{Sodium, Lithium, and Potassium}

With the exception of lithium, these cations are the major soluble species present in most waste streams, and their chemistries are very similar, due to their position in the same column on the periodic table. These cations are extremely soluble and are not bound in cementbased waste forms although they are present in neat portland cement at 0.2 to $1 \% \mathrm{Na}_{2} \mathrm{O}$ and 0.2 to $1.3 \% \mathrm{~K}_{2} \mathrm{O}$. Lea (1971) states that sodium and potassium may accelerate the hydration of $\mathrm{C}_{3} \mathrm{~S}$ and may affect the rate of precipitation of calcium hydroxide in cement pores.

Very little information is available on these cations alone, due to their association with anions in the solution (e.g. sulfate, carbonate, or nitrate) that themselves override any effect of the cations. These cations are, therefore, addressed in other sections of this report in the discussions of the various anions. 


\section{REVIEW OF RADIOACTIVE SPECIES THAT CAN BE IMMOBH IZED IN CEMENT-BASED WASTE FORMS}

Radioactive elements or adioelements, present in some wastes, are not known to interfere with the set of cement when they are immobilized. The main concern for these species is to succeed in tailoring a formulation which will "capture" and maintain them in the matrix. This is usually done by reducing the porosity of the waste forms, decreasing the permeability of the matrix, and increasing the tortuosity of the pore network to slow or halt the rate of diffusion of the radioactive species through the cement matrix. For some species, select additives having specific ion-exchange selectivity can be added to improve retention.

Some radioelements, as a result of their chemistry, will be more easily fixed in the cement structure. An example is ${ }^{90} \mathrm{Sr}$, which is an analogue of calcium and can, therefore, be substituted for calcium in cement chemistry. This cation will he released less easily because of its incorporation, or sorption, in or on the major cement hydrates, especially hydrated calcium aluminates (Glasser et al., 1985). The rates of release, however, will differ, because strontium is more soluble in alkaline solution than is calcium (Pottier and Glasser, 1986). In this case, strontium hydroxide will accompany calcium hydroxide at the ratios of their respective solubility products in the pore solution and will learh from the waste form.

Cesium and technetium, due to their greater mobility, will be more difficult to fix. Some additives (e.g. clays) can be added to the formulation to promote exchange of $\mathrm{Cs}^{+}$ions with others, such as $\mathrm{Na}^{+}$and $\mathrm{K}^{+}$, thus reducing the rate of diffusion of cesium into the environment by many orders of magnitude (Dole, 1985; Glasser et al., 1985). Technetium, on the other hand, needs to be reduced from its pertechnate soluble form (VII) to the more stable $\mathrm{TcO}_{2}$ (IV) form by using reducing agents such as BFS (Glasser et al., 1985).

The mobility of other radioactive species such as ${ }^{60} \mathrm{Co}$ are dominated by their chemistry. Transuranic species, such as uranium and plutonium, usually have such low leach rates from cement-based waste forms that they can barely be detected in many leaching studies. 
Lameille et al. (1986) studied the relationship between the leaching of $\mathrm{Cs}$, Sr, and Co and the microstructure of the portland cement in which they were immobilized. Their conclusion was that the majority (70\%) of these radioelements were fixed in cement hydrates. Cesium was poorly retained in the $\mathrm{CSH}$ and portlandite but was more often found in the aluminate-based hydrates. Strontium was poorly retained in the silicate hydrates and was found mainly in the calcium sulfoaluminate compounds. Cobalt, however, if present in large amounts, is fixed in new specific cobalt oxychloride-type compounds in the host matrix.

Data found in the literature on radioelement retention in cement mainly report on leach indices determined from immobilized radioactive species in cement-based waste forms. The leach indices are characteristic of a particular dry solid blend formulation, and a case-by-case examination needs to be performed. Grutzeck (1989) reported that tailoring waste-form composition enabled his team to improve the retention of radioactive species such as $\mathrm{Cs}, \mathrm{Sr}$, and $I$ by more than a factor of 10 .

\subsection{CESIUM}

The leaching mechanism of cesium from cement-based waste forms was studied by Atkinsun et al. (1983). They concluded that, in the case of waste forms which do not contain additives, cesium mobility involved only two mechanisms: adsorption onto the cement and diffusion through the cement matrix. When zeolites are added, there is another mechanism involved, which is the exchange of $\mathrm{Cs}^{+}$ions, captured in the crystalline network of such additives with the $\mathrm{Ca}^{2+}$ of the cement. Different studies show that, by using blended cement admixtures or sorbents, one can reduce significantly the release of cesium (Kumar and Roy, 1986; Kumar et al., 1987; Plodinec, 1977). Roy (1986) reports studies performed on cesium leaching by Atkinson that confirm that $\mathrm{Cs}^{+}$is primarly released by diffusion mechanisms from cement pastes while strontium is not.

Xuequan et al. (1991) compared the leachability, after a cure of 28 days, of three types of cement pastes containing $0.5 \mathrm{w} \% \% \mathrm{CsNO}_{3}$. The duration of the leaching test was 42 days. An alkali-activated slag cement released $8.1 \%$ of the cesium; an ordinary portland cement, $16.2 \%$; and a high aluminate cement $3.8 \%$. 
Fuhrmann and Colombo (1989) studied the releases of ${ }^{137} \mathrm{Cs}$ from samples containing $0.55 \mathrm{MBq}(15 \mu \mathrm{Ci})$ of ${ }^{137} \mathrm{Cs}$ in seawater and distilled water. This waste was immobilized in Type I portland cement and in cement containing $5 \%$ sodium sulfate matrices. They observed that the release of cesium was 10 times lower in seawater, probably due to the ionic strength of this leachant. They measured an effective diffusion coefficient of $4.8 \times 10^{-10} \mathrm{~cm}^{2} / \mathrm{s}$ for ${ }^{137} \mathrm{Cs}$ in seawater.

Radioactive waste solutions simulating four evaporator concentrates were immobilized by Plecas et al. (1992) in cement-based waste forms. Fifteen formulations were tested, with a cement/waste ratio varying from 0.26 to 1.0 . Each sample prepared contained $3 \times 10^{5} \mathrm{~Bq}$ ${ }^{137} \mathrm{Cs}$, and the two best formulations had diffusion coefficients, after 1 year of leaching, equal to 1.82 and $1.94 \times 10^{-11} \mathrm{~cm}^{2} / \mathrm{s}$. They found that leach rate increases with decreasing cement/waste ratio and decreases with increasing strength of the waste form.

Bernard et al. (1982) measured the amount of radionuclides released from full-scale leaching tests on cement-based waste forms. The cumulative fractional release data are presented in the following table, where $A_{n}$ represents the released activity for a time interval $(t)$, and $A_{0}$ represents the total activity for the considered isotope:

\begin{tabular}{|c|c|c|c|c|}
\hline Sample characteristics & ${ }^{137} \mathrm{Cs}$ & ${ }^{90} \mathrm{Sr}$ & ${ }^{239} \mathrm{Pu}$ & ${ }^{241} \mathrm{Am}$ \\
\hline $\begin{array}{l}\text { Sample I } \\
\text { - Waste form volume, } 200 \mathrm{~L} \\
\text { - Leaching time, } 9 \text { months } \\
\text { - Amount of radionuclides } \\
\text { contained in waste form: } \mathrm{A}_{0}(\mathrm{Ci}) \\
\text { - Fraction of radionuclides } \\
\text { released }\left(\Sigma \mathrm{A}_{n} / \mathrm{A}_{0}\right) \text { after } 9 \text { months }\end{array}$ & $\begin{array}{c}2.0 \\
0.031\end{array}$ & $\begin{array}{c}0.20 \\
0.0033\end{array}$ & $\begin{array}{c}0.16 \\
2.8 \times 10^{-6}\end{array}$ & $\begin{array}{c}0.80 \\
1.2 \times 10^{-6}\end{array}$ \\
\hline $\begin{array}{l}\text { Sample II } \\
\text { - Waste form volume, } 110 \mathrm{~L} \\
\text { - Leaching time, } 6 \text { months } \\
\text { - Amount of radionuclides } \\
\text { contained in waste form } \mathrm{A}_{0}(\mathrm{Ci}) \\
\text { - Fraction of radionuclides } \\
\text { released }\left(\Sigma \mathrm{A}_{\mathrm{\sigma}} / \mathrm{A}_{0}\right) \text { after } 6 \text { months }\end{array}$ & $\begin{array}{l}0.007 \\
0.0089\end{array}$ & $\begin{array}{c}0.006 \\
2.9 \times 10^{-4}\end{array}$ & $\begin{array}{l}\text { Absent } \\
\text { Absent }\end{array}$ & $\begin{array}{l}\text { Absent } \\
\text { Absen }\end{array}$ \\
\hline
\end{tabular}

Rebaggay and Dodd (1989) studied the leaching characteristics of a phosphate-sulfate waste grout produced from one $\mathrm{uf}$ the Hanford site tank wastes. This tank waste contained 
$0.48 \mu \mathrm{Ci} / \mathrm{L}^{137} \mathrm{Cs}$, and the resulting grout did not release measurable amounts of cesium into the leachates of the ANS 16.1 test after the initial washoff during the first day of the test.

The leaching properties of cesium were also studied by Torstenfelt and Hedin (1989) from a waste form containing $300-350 \mathrm{~kg} / \mathrm{m}^{3}$ powdered ion-exchange resin in a cement-based matrix. They measured an apparent diffusivity of cesium from the resin-cement matrix of 0.6 to $1.3 \times 10^{-10} \mathrm{~m}^{2} / \mathrm{s}$. When $5 \%$ zeolite by weight was added to the cement, the diffusivity decreas $2 \mathrm{t}$ to 0.8 to $1.0 \times 10^{-12} \mathrm{~m}^{2} / \mathrm{s}$.

Habayeb (1985) studied the release of ${ }^{134} \mathrm{Cs}$ from five treated decontamination wastes immobilized in cement-based matrices. The aim of his work was to find the best admixture when considering cesium release. The five solutions studied were peroxide bicarbonate ( $72.4 \mathrm{~g} / \mathrm{L} \mathrm{Na} \mathrm{CO}_{3} \cdot 10 \mathrm{H}_{2} \mathrm{O}, 34.3 \mathrm{~g} / \mathrm{L} \mathrm{NaHCO}_{3}, 20.3 \mathrm{~g} / \mathrm{L} \mathrm{H}_{2} \mathrm{O}_{2}$ ); alkaline permanganate $\left(30.0 \mathrm{~g} / \mathrm{L} \mathrm{KMnO}{ }_{4}, 100.0 \mathrm{~g} / \mathrm{L} \mathrm{NaOH}\right) ;$ Turco 4521A [33.0 $\mathrm{g} / \mathrm{L}\left(\mathrm{NH}_{4}\right)_{2} \mathrm{HC}_{6} \mathrm{H}_{5} \mathrm{C} ;, 17.0 \mathrm{~g} / \mathrm{L}$, $\mathrm{H}_{2} \mathrm{C}_{2} \mathrm{O}_{4}$ ); potassium perulfate $\left(54.1 \mathrm{~g} / \mathrm{L} \mathrm{K}_{2} \mathrm{~S}_{2} \mathrm{O}_{8}, 56.1 \mathrm{~g} / \mathrm{L} \mathrm{KOH}\right)$ and Turco $\quad 50.0 \mathrm{~g} / \mathrm{L}$ $\mathrm{H}_{3} \mathrm{PO}_{4}$ ). The three matrices tested, using Canadian cements, were type $30 \mathrm{p}$. nd cement, type 30 portland cement/bentonite, and type 30 portland cement/silicate. The waste forms were doped with ${ }^{134} \mathrm{Cs}$ at an average activity of $304 \mathrm{nCi} / \mathrm{mL}$. The results of this study show that the optimum formulations were sensitive to waste composition. However, the waste form obtaining the best results for containing cesium was the portland cement/bentonite blend. The leaching results of the various waste forms obtained at 80 days are summarized in the following table.

\begin{tabular}{lccc}
\hline & \multicolumn{3}{c}{ Cumulative releases of ${ }^{134} \mathrm{Cs}\left(\sum \mathrm{A}_{n} / \mathrm{A}_{0}\right)(100)$} \\
\cline { 2 - 4 } $\begin{array}{l}\text { Decontamination } \\
\text { waste }\end{array}$ & Type 30 PC & $\begin{array}{c}\text { Type 30 PC }+ \\
\text { bentonite }\end{array}$ & Type 30 PC + silicate \\
\cline { 2 - 4 } & 51.4 & 3.1 & 58.8 \\
\hline Peroxide bicarbonate & 46.0 & 3.0 & 59.4 \\
Alkaline permanganate & 54.1 & 8.4 & 57.5 \\
Turco 452.1 A & 81.1 & 17.9 & 80.7 \\
Potassium persulfate & 86.5 & 28.9 & 78.8 \\
Turco 4512 & & & \\
TC & &
\end{tabular}


Laboratory leaching experiments were performed by Walter et al. (1988) using a commercial low-level BWR waste stream that they immobilized in a cement-based matrix. The radionuclides present in the waste streams were ${ }^{60} \mathrm{Co}\left(1.58 \times 10^{3} \mu \mathrm{Ci} / \mathrm{L}\right),{ }^{137} \mathrm{Cs}$ $\left(2.34 \times 10^{3} \mu \mathrm{Ci} / \mathrm{L}\right)$, and ${ }^{134} \mathrm{Cs}\left(3.6 \times 10^{1} \mu \mathrm{Ci} / \mathrm{L}\right)$. After a 35-day ANS 16.1 leaching test performed on the waste forms, the measured cumulative concentrations in the leachate were $79.9 \%$ for ${ }^{137} \mathrm{Cs}, 51.9 \%$ for ${ }^{134} \mathrm{Cs}$ and only $0.5 \%$ for ${ }^{60} \mathrm{Co}$. Those cumulative concentrations correspond to average leach indices of 7.1 for ${ }^{137} \mathrm{Cs}$ and 11.3 for ${ }^{60} \mathrm{Co}$.

\subsection{STRONTIUM}

Atkinson et al. (1983) studied the leaching mechanisms of strontium from cement-based waste forms. Their conclusion was that strontium is chemically bonded to the cement hydrates by replacing $\mathrm{Ca}^{2+}$ in $\mathrm{CSH}$ or ettringite, a result corroborated by the study of Lameille et al. (1986). They also observed that, in the case of wastes containing high concentrations of sulfate, $\mathrm{Sr}^{2+}$ can be co-precipitated with $\mathrm{Ca}^{2+}$ through the formation of gypsum or ettringite. Strontium can also be included in insoluble carbonates when $\mathrm{CO}_{2}$ is dissolved in the leachant.

Fuhrmann and Colombo (1989) measured an $\mathrm{e}^{\mathfrak{f f}}$ ective diffusion coefficient of $2.5 \times 10^{-12} \mathrm{~cm}^{2} / \mathrm{s}$ when studying the leaching properties in seawater of an OPC sample containing $2.6 \mathrm{MBq}(70 \mu \mathrm{Ci}){ }^{85} \mathrm{Sr}$.

Atkins et al. (1991) observed that more than $99 \%$ of strontium added in hydrating fluids was immobilized in the solid phase, especially as ettringite.

In a study of the leachability of strontium from hydrofracture grouts, McDaniel et al. (1982) explored a variation of formulations containing the same additives added to simulated waste, but they modified their relative proportions in the blend. The concentration of strontium in each sample varied from 2.04 to $3.04 \mathrm{mg}$. They also measured the amount leached over 80 days, which ranged from 7.7 to $50.6 \%$ of the initial quantity. 


\subsection{TRANSURANICS}

Allard et al. (1984) studied the sorption of actinides in concrete systems. They observed that carbonates are mainly responsible for the formation of anionic, low-sorbing species with actinides in their higher oxidation states, such as neptunium(V) and uranium(VI). Precipitate formation explains the low release rates of these species during leaching tests. Roy (1986) confirms the fact that uranium species are relatively insoluble in cement pastes and that their release is not primarly diffusion controlled.

Berner (1990) studied uranium leachability from cement-based waste forms. He concluded that the cumulative uranium leached from the cement is nearly independent of the cement and leachant composition but is strongly dependent upon the solubilities of the uranium phases present in the waste form.

Kertesz et al. (1991) had to tailor a formulation to immobilize alpha incinerator ashes doped with ${ }^{238} \mathrm{Pu}$. The activity of the ash was $10 \mathrm{Ci} /$ metric ton. The initial activity in the waste form was $6 \times 10^{7} \mathrm{~Bq}(1.6 \mathrm{mCi})$, and, after 1 year, the cumulative fraction released was $5 \times 10^{-5}$.

Atkins et al. (1991) studied the retention of uranium in synthetic hydrated calcium uranium oxides. They observed that uranium (VI) reacts rapidly with cement to form a series of solubility-limiting compounds.

Leach tests were performed by Clark et al. (1983) on different waste forms containing plutonium. The cement-based waste form contained $4.38 \times 10^{-2} \mathrm{Ci}$ of plutonium, and the cumulative fraction released after 200 days was between $9.1 \times 10^{-6}$ and $5.9 \times 10^{-5}$, depending upon the nature of the leachant.

Thorium has a similar chemistry to that of uranium and should not present a problem when stabilized in cement-based matrices. This metal and the uranium family form insoluble compounds that should not leach easily from such waste forms. This hypothesis, however, is not confirmed, as data on thorium were not found during the literature search. 


\subsection{COBALT}

Rebaggay and Dodd (1989) evaluated the leaching characteristics of phosphate-sulfate waste grouts from the Hanford site. One of the tanks studied contained $6.67 \mu \mathrm{Ci} / \mathrm{L}$ of ${ }^{60} \mathrm{Co}$. The measured leachability index at the end of a 90 -day test was 10.9 for this radioelement.

A formulation containing $90 \% \mathrm{BFS}$ and $10 \%$ OPC was developed to immobilize the Winfrith reactor sludge (Lee et al., 1986). This sludge contained ${ }^{60} \mathrm{Co}$ at an average concentration of $2.5 \times 10^{11} \mathrm{~Bq} / \mathrm{m}^{3}$. Using a cement/sludge weight ratio of 0.51 , the authors measured $\mathrm{a}^{60} \mathrm{Co}$ leach rate of $10^{-6}$ to $10^{-9} \mathrm{~cm} /$ day during the firs: 100 days of leaching.

The theoretical study of Lameille (1986) suggests that cobalt combines with $\mathrm{OH}^{-}$to form specific cobalt-containing hydrates. These hydrates are supposedly cobalt oxycloride and are found mainly around the silicates.

\subsection{TECHNETIUM}

Technetium is well known to be a difficult radioelement to immobilize in cement-based waste forms because of its high mobility in its predominant anionic soluble form $\left(\mathrm{TcO}_{4}{ }^{-}\right)$.

Therefore, many studies have been conducted to improve formulations to immobilize this species. The general conclusion, from most of the literature, is that a reducing additive such as BFS must be used in order to accomplish the following:

1. Reduce the extremely soluble pertechnetate ion $\mathrm{TcO}_{4}^{-}(\mathrm{VII})$ to technetium oxide $\mathrm{TcO}_{2}$ (IV), which is less soluble. The reducing redox environment formed by slags is due to the sulphur species released during the hydration of the slag, as well as ferrous and manganese (II) ions.

2. Lower the porosity and permeability of the waste form by the addition of BFS. Also, the tortuosity of the pore network is increased, thus slowing the mobility of ${ }^{99} \mathrm{Tc}$ and many other radioelements as well. 
Gilliam et al. (1988) and Bostick et al. (1988) worked with a heavy metal sludge from Portsmouth, Ohio, containing $5.1 \mu \mathrm{g} / \mathrm{g}$ of technetium. Previous studies with the same waste, using fly ash as an additive to a Type I-II portland cement, resulted in a leach index for ${ }^{99} \mathrm{Tc}$ of only 6.1. In the work of Gilliam and Bostick, six different blast furnace slags were studied, and leach indices averaging 10.5 for this problematic species were obtained.

Tallent et al. (1989) developed a formulation for the immobilization of a DSSF waste from the Hanford site. They utilized technetium and nitrate release properties of the resulting grout to investigate the confinement properties of the final waste form developed.

Technetium was used as a tracer in the simulated waste. All the formulations studied, except one, contained BFS at different weight ratios in the dry blend mixture. The overall average technetium leach index obtained was above 8.

Bostick et al. (1989) worked on the treatment and disposal of heavy metals slurry waste from the Portsmouth site containing soluble ${ }^{99} \mathrm{Tc}$. The concentration of technetium in the heavy metals slurry filtrate was $13 \mathrm{mg} / \mathrm{L}$. After immobilizing this filtrate in grout, the following results were obtained: a grout without BFS, containing filtrate pretreated with iron, obtained a leach index of 10.4; the filtrate, immobilized in the same grout but without a pretreatment step, resulted in a leach index of 8.6; and a grout containing BFS produced an index of 10.5 .

The Defense Waste Processng Facility salt solution from the Savannah River Site containing $75.3 \mu \mathrm{Ci} / \mathrm{L}^{99} \mathrm{Tc}$, was studied by Langton (1989). A slag-based saltstone formulation yielded an effective diffusion coefficient of $3.9 \times 10^{-12} \mathrm{~cm}^{2} / \mathrm{s}$, while a cement-based saltstone obtained about $5 \times 10^{-9} \mathrm{~cm}^{2} / \mathrm{s}$. 


\section{REVIEW OF ORGANIC SPECIES THAT MAY INTERFERE WITH VARIOUS WASTE-FORM PROPERTIES}

In the context of the FFCA project, waste streams loaded with organics are supposed to be thermally treated to destroy the organic species before the waste is solidified in the cementbased matrix; therefore, emphasis examining the effect of organics was not emphasized during this literature search. Recent literature searches performed by Spence et Osborne (1993) and Trussel and Spence (1992), developed in more detail the action of organic species on $\mathrm{S} / \mathrm{S}$ with cement-based material.

Organic compounds are commonly used in the cement and concrete industry to serve as water reducers and plasticizers. Of these organic compounds, lignosulfonic acids and their salts, citric acids, and gluconic acids act as water reducers, while naphthalene compounds, melamine, and sulfonated hydrocarbons act as plasticizers or superplasticizers. Plasticizers are known to retard set without affecting the total heat of hydration, and superplasticizers stabilize the formation of ettringite by inhibiting its normal evolution into calcium monosulfoaluminate.

Organic speries such as these have a well-known effect upon the normal hydration of cement, and the concentration at which they are introduced is closely controlled. Their controllable, beneficial action cannot be compared with that of the organics found in many waste streams.

Many researchers, when reporting results of studies using S/S to immobilize organic wastes, arrive at a common conclusion: that is, $\mathrm{S} / \mathrm{S}$ technologies are generally not appropriate to treat organic-bearing wastes (Wiles and Barth, 1992; Brown et al., 1992). However, in some mixed wastes, the ar. ount of organic species present cannot justify some pretreatment options (such as thermal pretreatment or incineration), due to cost limitations. Incineration can transform other waste species such as heavy metals into compounds more difficult to stabilize later. Therefore, S/S might be considered for these kinds of waste. 
Many authors discuss the inability of the available tests such as the TCLP to evaluate the retention of organics in cement-based waste forms, due to the fact that many organics are not miscible in water or acetic acid solution.

Another concern related to the stabilization of organics in cement-based waste forms is that the mechanical action of mixing, as well as the heat generated by the hydration of cement during mixing and curing may lead to evaporation and loss of the more volatile species of organics.

To illustrate the influence of organics present in actual mixed waste streams upon S/S processes, we may cite examples from the SITE program of the EPA. For this program, commercial $\mathrm{S} / \mathrm{S}$ processes are tested on real contaminated wastes. The sites are contaminated with inorganic species such as heavy metals, as well as oil, greases, and various other organics. Interpretation of results is usually inconclusive regarding the presence of organic species, according to de Piercin (1990) and Brown et al. (1992). They report results obtained from three EPA Superfund sites that illustrate this problem. They state that very little scientific literature claims that $S / S$ is effective for treating organic wastes.

Some studies investigated the mechanism of retention of organic species in cement products. Wiles and Barth (1992), for example, reported that organics are unlikely to form insoluble precipitates; neither do organics enter into the structure of cement hydrates. Therefore, physical encapsulation will be the principal way to contain organics in cement-based waste forms. They conclude that $\mathrm{S} / \mathrm{S}$ processes, "should follow some earlier stage of treatment for removal and/or destruction of the volatile and semivolatile constituents."

This idea of pretreatment is shared by Pollard et al. (1991), who, in their review of the fffect of organic waste upon cement, discuss preabsorption of organic contaminants as a pretreatment step for mixed waste organics. The EPA handbook (U.S. EPA, 1989) contains a brief review of organic compounds known to interfere with cement hydration and mentions some pretreatment steps which can be employed. 
Generally, organics can interfere with the development of the cement matrix during the set, or alter the durability of the final waste form. Usually, organics are considered as retarders for the set of cement. Young (1972) made a critical review of the various mechanisms that explain the retardation effect on the set of cement when some "retarder" species are added. He summarized the mechanisms into four groups: (1) absorption, (2) precipitation, (3) complexation, and (4) nucleation control.

Upon considering the effect of organics upon the set of cement, he concluded that the following two retardation effects are probably combined:

1. retardation of the hydration of tricalcium silicate $\left(C_{3} S\right)$ through the adsorption of organics onto calcium hydroxide nuclei, and

2. retardation by adsorption of organics onto the initial products of tricalcium aluminate $\left(\mathrm{C}_{3} \mathrm{~A}\right)$.

Banfill and Saunders (1986) used organics from two groups of compounds, carbohydrates and substituted aromatic compounds, to conduct their study. They studied organic concentrations of $0.05 \mathrm{M}$ in aqueous solution. They concluded that nucleation and growth of calcium hydroxide are hindered by retarding organics.

Authors such as Tittlebaum et al. (1985) stated that triethanolamine (TEA), even at low concentrations, up to $0.5 \%$, alters the set of portland cement. At concentrations between 0.17 and $0.5 \%$ TEA, the initial set time is accelerated; however, the final set is retarded, and the physical structure of the waste form does not mature.

Cartledge et al. (1989) studied three organic compounds miscible with water: ethylene glycol and two forms of phenol, $p$-chlorophenol and $p$-bromophenol. Their conclusion was that cement alone is not able to immobilize these compounds. In concentrations up to $20 \%$ based on the weight of cement, ethylene glycol slows the rate of hydration of cement; otherwise, the hydration process occurs normally. At concentrations above $20 \%$, the cement does not set at all. It was also reported that ethylene glycol is not bonded to the cement structure, because 
recoveries of up to $100 \%$ can be obtained in a one-step leach test. UCS and porosity are greatly modified for concentrations above $10 \%$ ethylene glycol.

The two forms of phenol studied increased the set time, with $p$-chlorophenol having the most pronounced effect. Immobilization by cement is not obtained for either form. Phenol compounds apparently allow the normal mechanism of hydration to occur even if the kinetics are slowed. For concentrations up to $10 \%$, the modifications are still minor for all three compounds; however, incorporation of $20 \%$ or more induced major changes.

It appears that phenol compounds were studied more often than other types of organics. Vipulanandan and Krishnan (1990) incorporated 0.5 and $2 \%$ by weight pure phenol in Type I portland cement. The addition of $2 \%$ phenol increased the set time by a factor of 3 . TCLP leaching tests reccvered up to $100 \%$ of the organics in the leachate, proof that phenol is not chemically bound to the cement structure.

Kolvites and Bishop (1989) used a solution containing $4 \mathrm{~g} / \mathrm{L}$ of phenol or $1.1 \mathrm{~g} / \mathrm{L}$ trichloroethylene (TCE) to hydrate a Type II portland cement (water:cement ratio $=0.50$ ). They conducted column leach tests in both cases to study the retention of each species in the cement paste. Using a mathematical model, they calculated leach indices varying between 7.7 and 8.2, depending upon the cure time of the system. Leach indices were impossible to calculate for TCE, due to the evaporation of this very volatile compound even before the beginning of the leach test. They also observed very little interaction between phenol and cement, but TCE appeared to produce some decomposition products and, therefore, might chemically react with cement.

Sell et al. (1992) studied the interaction of phenol, trichlorophenol (TCP), and pentachlorophenol (PCP) at a concentration of $1 \mathrm{~g} / \mathrm{kg}$ ir a soil sample. They stabilized this contaminated soil by adding clays ano Type I portland cement. The TCLP test performed on these waste forms resulted in the following concentrations measured in the leachates: 25 to $29 \mathrm{mg} / \mathrm{kg}$ for TCP, 1.9 to $31.3 \mathrm{mg} / \mathrm{kg}$ for PCP, and 7 to $49 \mathrm{mg} / \mathrm{kg}$ for phenol. 
Shukla et al. (1992) showed that the leaching performance of PCP and phenol is better when the cure time is increased. They studied concentrations up to $10 \mathrm{mg}$ PCP for $10 \mathrm{~g}$ of Type I portland cement and $10.4 \mathrm{mg}$ phenol for $10 \mathrm{~g}$ of Type II portland cement. In their study, phenol appears to leach more rapidly than TCP from the waste forms, by factors of 6 to 10 , depending upon the cure time.

Cote et al. (1990) prepared a reconstituted sludge containing $500 \mu \mathrm{g}$ per gram of sludge of acenaphthene, aniline, bis(2-chloroethyl)ether, phenol, and lithium. They tested five commercial processes with the contaminated sludge, and measured the ability of the waste form to contain those species by performing a dynamic leaching test (ANSI/ANS-16.1). The leach indices obtained are as follows:

- Lithium

- Acenaphthene

- Aniline

- Bis(2-chloro-ethyl)ether

- Phenol
6.3 to 8.2

9.0 to 11.6

7.3 to 10.0

8.5 to 10.8

6.2 to 10.7

Cote et al. concluded that physical containment was the most important factor for phenol and aniline, while acenaphthene and bis(2-chloroethyl) ether were somehow chemically bonded onto the cemeat structure.

Greenhalgh (1985) incorporated $20 \mathrm{wt} \%(40 \mathrm{vol} \%)$ of waste oil or solvent in a waste form. Upon adding an emulsifier and an aqueous phosphate additive to portland cement, he was able to produce acceptable waste forms for disposal. Greenhalgh concluded that solvent waste loadings up to $45 \mathrm{vol} \%$ can be incorporated into cement by adding the correct additives, but concentrations above $40 \%$ might not be able to pass 10 CFR 61 test requirements.

Riaz and Zamorani (1989) studied the effect of 1,3,5-trichlorobenzene (TCB) in cement. The water:cement weight ratio used was 0.40 , and the ratio of solid organic waste to cement, by weight, was up to 0.20 . For this last concentration, the average amount of $1,3,5-\mathrm{TCB}$ in the cement sample was $2.70 \mathrm{~g}$, and the amount leached at 120 days was $193.5 \mu \mathrm{g}$ in $400 \mathrm{~mL}$ of 
leachate. Despite that, 1,3,5-TCB was a retarder for the rate of hydration, and the authors conclude that this cement matrix is acceptable for this organic.

The influence of ethyl alcohol and 1-4 dioxane on some Type I portland cement properties was studied by Muhua and Roy (1987). Their study focused primarily on rheological properties, using these species as part of the hydrating solution for the cement at as high as $30 \mathrm{vol} \%$. For $30 \%$ dioxane in the solution, they observed a substantial retardation of the cement set. Ethyl alcohol is reported as a retarder for the set, but has a more pronounced effect than dioxane because the alcohol is more readily adsorbed on cement particle surfaces.

A portland cement richer in the $\mathrm{C}_{2} \mathrm{~S}$ phase than normal was used by Singh et al. (1986a; 1986b) to study the effect of lactic and citric acid upon hydration. Contrary to the behavior of other hydroxy carboxylic acids, which act as retarders, lactic acid accelerated the rate of hydration. Concentrations up to $0.4 \mathrm{wt} \%$ in solution were incorporated, with a water:cement ratio of 0.25 in the cement. Results showed that lactic acid, at all the concentrations studied, accelerated the set by accelerating the hydration of the aluminate phase.

When these researchers incorporated citric acid into the solution, at concentrations up to $0.4 \mathrm{wt} \%$ based upon the cement using 0.20 and 0.25 water/cement ratios, they observed two phenomena. For $0.1 \%$ citric acid concentration, they measured an acceleration of the set, while higher concentrations were retarding. They determined by zeta potentiometry measurements that adsorption of citrate ions at the surface of the cement grains was responsible for the retardation observed.

Stinson and Sawyer (1989) reported on a S/S demonstration performed at one of the Superfund sites of a soil that contained, among other contaminants, polychlorinated biphenyls (PCBs). Average concentrations of $300 \mathrm{mg} / \mathrm{kg}$ PCB were found on the site, with maxima up to $950 \mathrm{mg} / \mathrm{kg}$. The leachate of the TCLP performed on the untreated soil contained up to $13 \mu \mathrm{g} / \mathrm{L}$ of PCB. After injection of the additives and mixing with the soil, the measured concentration of the treated soil dropped to an average of $110 \mathrm{mg} / \mathrm{kg}$, with maxima up to $170 \mathrm{mg} / \mathrm{kg}$. TCLP tests performed on the treated samples yielded concentrations below the detection limit of $1 \mu \mathrm{g} / \mathrm{L}$. 
This site was also contaminated with volatile organic compounds (VOCs) at a total concentration up to $1485 \mathrm{mg} / \mathrm{kg}$. The disturbance of the soil by the stabilization process yielded results which were inconclusive for the fixation of VOCs by this process.

Spence et al. (1992) studied the immobilization of a sludge heavily loaded to about $1 \%$ metals and containing $<0.04 \%$ VOCs. Such waste could not be pretreated economically at this low level of VOC contamination, and $\mathrm{S} / \mathrm{S}$ was considered as a possible alternative for stabilizing the contaminated soil. A static leach test was considered more appropriate than the TCLP test to better study the containment of the organic species in the waste forms. Leach indices obtained ranged from 6.0 to 9.4. The conclusion was that, in order to pass the TCLP test, the sludge organic concentration must be limited to a concentration of $1000 \mathrm{mg} / \mathrm{kg}$, and the correct additives must be used in the solids formulation.

Stegeman and Cote (1990) reported the results of an investigation of test methods for solidified waste evaluation. Five different wastes, as well as the solidified products obtained using 15 proprietary solidification processes, were evaluated by four independent laboratories. TCLP was performed, among other tests, on the raw and solidified products. Three of the five wastes studied contained organics. The authors concluded that solidification was not a good technology for organics stabilization. The results obtained are presented in the following table.

\begin{tabular}{|c|c|c|c|}
\hline Organic species & $\begin{array}{l}\text { Concentration in } \\
\text { the raw waste } \\
(\mathrm{mg} / \mathrm{kg})\end{array}$ & $\begin{array}{l}\text { TCLP concentration } \\
\text { (mg/L) of the raw } \\
\text { waste }\end{array}$ & $\begin{array}{l}\text { Range of the TCLP } \\
\text { concentration }(\mathrm{mg} / \mathrm{L}) \text { of the } \\
\text { solidified waste }\end{array}$ \\
\hline Phenol & 3,700 & 3,700 & $0.07-144^{a}$ \\
\hline Pentachlorophenol & 11,000 & 33.7 & $3.0-162^{b}$ \\
\hline $\begin{array}{l}\text { Polyaromatic } \\
\text { Hydrocarbons }\end{array}$ & 300 & $<1.2$ & All 13 undetected \\
\hline $\begin{array}{l}\text { Polychlorinated } \\
\text { Biphenyls }\end{array}$ & 7 & $<0.00006$ & All 15 undetected \\
\hline
\end{tabular}




\section{SUMMARY AND CONCLUSIONS}

A comprehensive literature search has been performed with the objective of determining waste characterization needs to support cement-based waste-form development. More specifically, the goal was to determine which waste species are problematic in terms of consistent production of an acceptable cement-based waste form, and at what concentrations these species become intolerable. The literature search has confirmed that the knowledge of cement-based waste-form chemistry has not progressed to the point where this is possible.

Research to date in the area of cement chemistry has focused primarily on the simplest system: cement, water, and the species of interest. The majority of these studies have provided neither the definitive rationale for the mechanism of interaction between the species and the cement-water paste nor the absolute concentrations at which the interaction occurs. In addition, limited research into the synergistic effect of multiple species shows that while synergistic effects definitely occur, the mechanism of interaction and the concentration levels remain poorly defined.

What is clear from the literature search is that cement-based waste forms, sometimes referred to as a "low-tech option," are anything but simple from the standpoint of waste-form chemistry. Indeed, cement waste-form chemistry is extremely complex and is poorly understood even for some simple system of a single waste constituent in a cement-water paste. It is also clear that the following generalization can be made based upon the collective information presented in this report: the effects of any species on the cement-water paste chemistry are dependent on the matrix components, the chemical form of the species of interest, its solubility in the paste environment, and its ability to contact the cement and, hence, interact. Consequently, quantifying the species of interest and the threshold concentration of that species in an actual waste becomes even more complex due to the nature of the waste itself. The waste is virtually never a single chemical species, but is usually a complex mixture of crystalline and/or amorphous material composed of a variety of chemical constituents present in soluble and/or insoluble form. The chemical form of the species of interest, the solubility of the species of interest, and the ability of the species to contact the cement are factors complicating the waste-form environment. 
The literature search has clearly established that no definitive waste characterization requirements exist. Consequently, only general guidance as to the waste constituents and concentrations of interest can be derived from available data. It is recognized that waste characterization is a costly and time-consuming endeavor. Considering the generic nature of the guidance that can be provided, it is not cost-effective to define an exhaustive list of species. More detailed characterization data needs will develop as experience is gained with each waste in the laboratory-scale treatability studies.

Consequently, the approach to waste characterization needs presented is to request "screening type" characterization. The basic approach is to gather sufficient characterization data to know if a potential "problem species" is present and to utilize the treatability studies to determine if a problem exists. The screening data will suggest potential causes of the problem and provide guidance as to constituents requiring more detailed quantified analyses. It must be clearly understood that this approach requires that archived waste samples be maintained, so that additional analyses can be performed at a later date if required.

\subsection{GENERAL CHARACTERIZATION}

From the text, it is clear that the interaction of a given constituent is greatly influenced by its chemical form and its ability to become mobile/soluble in the aqueous phase. Consequently, the gross chemical form of the waste must be known. In addition, large amounts of discretely identifiable materials, salts and/or chemicals that were added to the waste stream should be identified. This information can be routinely obtained through process knowledge rather than detailed analyses. For example, the Pond Waste Management Project Sludge (an F006 material) is, through process knowledge, known to generally be a hydroxide sludge containing significant quantities of fluoride and chloride salts, as well as ion-exchange resins.

In addition to the gross chemical form characterization, the solid (or liquid) content must be determined. Water (or the liquid phase) provides the principal means of interaction between the waste and the cement. In addition, the $\mathrm{pH}$ of the liquid phase should be determined. 


\subsection{RCRA METALS}

The principal focus of waste-form development is to reduce or restrict the mobility of metals that the EPA considers hazardous. As discussed in the text, many of these metals can also interfere with the cement reactions. For purposes of waste characterization needs, the assumption is made that EPA regulatory concerns dictate the metal concentrations of interest rather than their potential impact on the cementitious reactions. In general, the effectiveness of reduction in mobility of metallic constituents is determined by their concentration levels in the TCLP leaching test. Consequently, a TCLP should be performed on the raw waste to determine the baseline "mobility" of the hazardous metal constituents.

In addition, recognizing that the test leachate "dilutes" the solid waste concentration by at least a factor of 20 ( $100 \mathrm{~g}$ of solid is extracted in $2000 \mathrm{~mL}$ of fluid), one can calculate the minimum solid waste concentrations to be at least 20 times the determined TCLP concentrations if one assumes, in the worse scenario, that all the hazardous species is released. Thus, the TCLP provides a qualitative and quantitative analyses of these metals for comparison with data discussed in Section 8.3. EPA sets the following limits on TCLP leachates:

\begin{tabular}{lc}
\hline \multicolumn{1}{c}{ Species } & Concentrations of interest $(\mathrm{ppm})$ \\
\hline Arsenic & $<5$ \\
Barium & $<100$ \\
Cadmium & $<1$ \\
Chromium & $<5$ \\
Lead & $<5$ \\
Mercury & $<0.2$ \\
Selenium & $<1$ \\
Silver & $<5$ \\
\hline
\end{tabular}




\subsection{ADDITIONAL METALS/CATIONS}

Numerous metals/cations may participate in the cementitious reactions, depending on factors such as concentration and environment. Consequently, it is reasonable to perform a quick screen on both the liquid and solid phase of the waste in order to ascertain the presence of these species. Although it is beyond the scope of this report to specify the required analytical method, one relatively inexpensive method known to the authors which addresses the majority of the metals/cations discussed in the text is the inductively coupled plasma - atomic emission spectroscopy (ICP). Therefore, ICP analyses, or equivalent, are requested for both the liquid and solid phase based on the assumption that said analyses provide data with respect to the following species: $\mathrm{Ag}, \mathrm{Al}, \mathrm{As}, \mathrm{B}, \mathrm{Ba}, \mathrm{Be}, \mathrm{Ca}, \mathrm{Cd}, \mathrm{Co}, \mathrm{Cr}, \mathrm{Cu}$, $\mathrm{Fe}, \mathrm{K}, \mathrm{Li}, \mathrm{Mg}, \mathrm{Mn}, \mathrm{Mo}, \mathrm{Na}, \mathrm{Ni}, \mathrm{P}, \mathrm{Pb}, \mathrm{Sb}, \mathrm{Se}, \mathrm{Si}, \mathrm{Sn}, \mathrm{Sr}, \mathrm{Ti}, \mathrm{V}, \mathrm{Zn}$, and $\mathrm{Zr}$. Note that this assumption is based upon a listing of analyses using ICP provided by the ORNL Analytical Chemistry Division.

\subsection{ANIONS}

Numerous anions have been shown to effect the cementitious reactions. These include chloride, carbonate, sulfate, sulfide, sulfite, nitrate, nitrite, hydroxide, silicate, borate, phosphate, and fluoride. However, as discussed in Sect. 5, these constituents appear to significantly effect the cementitious reactions when they are present as major constituents in the waste (i.e., $>1 \mathrm{wt} \%$ ). Consequently waste characterization limits for all of these constituents are specified as $>1 \mathrm{wt} \%$. However, if the methodology used for analysis of these constituents will provide data at lower concentrations for the same cost, the analytical detection limit should be reported.

\subsection{U.S. DEPARTMENT OF TRANSPORTATION REGULATIONS}

Ultimately, waste samples must be shipped to a site where treatability studies will be performed. Consequently, sufficient analyses should be performed to ensure compliance with applicable DOT regulations. For hazardous constituents, both the hazard code (e.g., F006) and the analytical data to support that determination are required. Examples of 
additional characterization data pertaining to shipping include material classification as a solid or liquid (per 49 CFR 171.8) and radionuclide analyses required to determine proper shipping container (per 49 CFR 173).

Interpretation of $49 \mathrm{CFR}$ requirements is beyond the scope of this report. However, information on this issue related to radionuclide characterization for vendor operational readiness review approval is presented for guidance. At a minimum, appropriate analyses must be performed to identify total activity in the waste and the types and concentrations of radionuclides present, particularly the presence (or lack) of special nuclear material. The general analytical approach should be to conduct the following tests.

1. Alpha/beta/gamma screens should be performed to determine waste unit in curies per gram activity and aggregate activity in curies of the total volume to be shipped.

2. An analysis for total uranium (e.g., parts per million) and an isotopic assay should be performed.

3. Any Special Nuclear Material constituents present, such as isotopes of plutonium, ${ }^{233} \mathrm{U}$, and ${ }^{235} \mathrm{U}$ should be identified and quantified (mass basis). Quantification of ${ }^{235} \mathrm{U}$ is not necessary unless an assay of $0.71 \%$ uranium has been determined, in which case ${ }^{235} \mathrm{U}$ content may be established via determination of total uranium content versus isotopic assav.

4. Deturmination of the need for additional radionuclide analyses $(\mathrm{Cs}, \mathrm{Co}, \mathrm{Np}, \mathrm{Sr}, \mathrm{Tc}, \mathrm{Th}$, etc.) must be made on a case-by-case basis and should be based on

- ability of foregoing information to "close" an activity balance on the waste with a high degree of confidence (i.e., the sum of identified radionuclides and their specific activities account for the total activity present), and/or

- available process knowledge indicating the potential presence of other radionuclides, 
with at a minimum, waste derived from enrichment/diffusion plant activities should be analyzed for technetium.

5. The sample preparation and analytical method as well as sensitivity for all analyses performed should be reported to assist data evaluation.

\subsection{OFF-SITE DISPOSAL}

The final disposition plan for the stabilized wastes is not known at this time. It will be dictated by technical and political constraints and the availability of disposal space. It is anticipated that the demand for disposal volume will be extensive. To meet this demand, all disposal options are being considered, including off-site disposal. Currently, potential offsite commercial disposal for mixed waste is limited to Envirocare. Therefore, sufficient radionuclide characterization should be performed to evaluate the waste compatibility with Envirocare's radioactive material license. As such, the following analyses in picocuries per gram are required: ${ }^{234} \mathrm{U},{ }^{235} \mathrm{U}$, natural uranium, depleted uranium, ${ }^{137} \mathrm{Cs},{ }^{99} \mathrm{Tc},{ }^{230} \mathrm{Th}$, and

${ }^{232} \mathrm{Th}$. As in Sect. 8.5, both the sample preparation and analytical method, as well as sensitivity for all analyses performed, should be reported to assist data evaluation.

\subsection{ORGANICS}

As discussed in the text, organic constituents have the ability to interact with the cementitious reactions even when present at the level of parts per million. Although this is known to be true, the assumption is made that organic waste constituents will be treated to meet LDR requirements in a pretreatment step prior to stabilization. Consequently, the specific organic analyses required will be addressed by other projects supporting the FFCA/LDR and will not be presented in detail here. However, considering the parallel nature of the projects supporting the FFCA/LDR, some indication of their presence in the waste sample received for waste-form development is required. Consequently total organic carbon analysis is requested to serve as that indicator. 


\subsection{QUALITY ASSURANCE}

Waste characterization data needs have been identified which address shipping, treatability study regulations, and waste-form chemistry. It must be noted that the requested waste characterization data, summarized in Table 3, are generic and should be viewed as "screening type" data. As such, sufficient quantities of waste samples should be archived so that more exhaustive characterization can be performed at a later date. Specifying the exact analytical methods for data acquisition is beyond the scope of this report as these methuds will need to be determined by (1) analytical experience and knowledge of effective methods, (2) schedule, (3) budget, and (4) regulatory requirements. From the perspective of the Final Waste Form Project, the primary driver is that the data be technically defensible. In this regard, the assumption is made that the detailed quality assurance/quality control requirements will be specified by the group that actually obtains the waste samples. However, the Final Waste Form Project requires, at a minimum, documentation of the following information on characterization data: procedures on sampling and analyses, confidence limits or levels, and chain of custody.

\subsection{FUTURE NEEDS}

This report has focused on the minimum characterization needs, assuming that current cost and schedule constraints will not support an extensive characterization effort for all of the Appendix B wastes at this time. These screening data are sufficient only for initial "proof-ofprinciple" treatability studies. Ultimately, a more detailed characterization will be required. These requirements will include the following:

1. The variability [concentration range (e.g., minimum and maximum)] of all hazardous constituents and radionuclides must be known, as they are the principal regulatory drivers with respect to product acceptability.

2. The variability [concentration range (e.g., minimum and maximum)] of the principal or major waste constituents ( $>1 \mathrm{wt} \%$ ) must be known, as they will certainly dominate the waste-form chemistry and handling properties. 
3. Sufficient analytical archived samples should be maintained, based upon the assumption that additional characterization data, beyond that presented in this report, will have to be obtained using the number of replicates defined in the analytical quality assurance plan. As development efforts are completed, both trace (minor) and major constituents of concern will be identified by experimentation. The archived samples can then be retrieved and the variability of these constituents determined.

Recognizing the cost and time involved in defining and obtaining sufficient statistically significant samples to determine the variability of waste constituents, it is a reasonable assumption that this analysis can be performed only on a limited number of Appendix B wastes in time to support the initial treatability studies. However, the reader should be aware of the need for this type of information and obtain the more detailed characterization when feasible to do so. 
Table 3. Waste characterization data required to support the development of grout waste forms

\begin{tabular}{|c|c|c|c|c|}
\hline \multirow{2}{*}{$\begin{array}{l}\text { Characterization } \\
\text { requirements }\end{array}$} & \multirow{2}{*}{ Section } & \multicolumn{2}{|c|}{ Performed on } & \multirow{2}{*}{$\begin{array}{c}\text { Analytical } \\
\text { Quantification } \\
\text { Limits } \\
\end{array}$} \\
\hline & & Solid & Liquid & \\
\hline $\begin{array}{l}\text { Gross characterization/ } \\
\text { description }\end{array}$ & 8.1 & $\begin{array}{l}\mathbf{Y} \\
\mathbf{Y}\end{array}$ & $\begin{array}{l}\mathbf{Y} \\
\mathbf{Y}\end{array}$ & \\
\hline $\begin{array}{l}\text { Water content } \\
\mathrm{pH}\end{array}$ & & $\mathbf{Y}$ & $\mathbf{Y}$ & \\
\hline $\begin{array}{c}\text { TCLP } \\
\mathrm{As} \\
\mathrm{Ba} \\
\mathrm{Cd} \\
\mathrm{Cr} \\
\mathrm{Pb} \\
\mathrm{Hg} \\
\mathrm{Se} \\
\mathrm{Ag}\end{array}$ & 8.2 & $\begin{array}{l}\mathbf{Y} \\
\mathbf{Y} \\
\mathbf{Y} \\
\mathbf{Y} \\
\mathbf{Y} \\
\mathbf{Y} \\
\mathbf{Y} \\
\mathbf{Y}\end{array}$ & $\begin{array}{l}\mathbf{Y} \\
\mathbf{Y} \\
\mathbf{Y} \\
\mathbf{Y} \\
\mathbf{Y} \\
\mathbf{Y} \\
\mathbf{Y} \\
\mathbf{Y}\end{array}$ & $\begin{array}{rl}\text { 5. } & \mathrm{ppm} \\
100 . & \mathrm{ppm} \\
1 . & \mathrm{ppm} \\
5 . & \mathrm{ppm} \\
5 . & \mathrm{ppm} \\
0.2 & \mathrm{ppm} \\
1 . & \mathrm{ppm} \\
5 . & \mathrm{ppm}\end{array}$ \\
\hline $\begin{array}{l}\text { ICP a } \\
(\mathrm{Ag}, \mathrm{Al}, \mathrm{As}, \mathrm{B}, \mathrm{Ba}, \mathrm{Be}, \mathrm{Ca}, \mathrm{Cd} \text {, } \\
\mathrm{Co}, \mathrm{Cr}, \mathrm{Cu}, \mathrm{Fe}, \mathrm{K}, \mathrm{Li}, \mathrm{Mg}, \\
\mathrm{Mn}, \mathrm{Mo}, \mathrm{Na}, \mathrm{Ni}, \mathrm{P}, \mathrm{Pb}, \mathrm{Sb} \\
\mathrm{Se}, \mathrm{Si}, \mathrm{Sn}, \mathrm{Sr}, \mathrm{Ti}, \mathrm{V}, \mathrm{Zn}, \mathrm{Zr})\end{array}$ & 8.3 & $\mathbf{Y}$ & $\mathbf{Y}$ & \\
\hline $\begin{array}{l}\text { Anions/Salts } \\
\text { Chloride } \\
\text { Carbonate } \\
\text { Sulfate } \\
\text { Sulfide } \\
\text { Sulfite } \\
\text { Nitrate } \\
\text { Nitrite } \\
\text { Hydroxide } \\
\text { Silicate } \\
\text { Borate } \\
\text { Phosphate } \\
\text { Fluoride }\end{array}$ & 8.4 & $\begin{array}{l}\mathbf{Y} \\
\mathbf{Y} \\
\mathrm{Y} \\
\mathrm{Y} \\
\mathrm{Y} \\
\mathrm{Y} \\
\mathrm{Y} \\
\mathrm{Y} \\
\mathrm{Y} \\
\mathrm{Y} \\
\mathrm{Y} \\
\mathrm{Y}\end{array}$ & $\begin{array}{l}Y \\
Y \\
Y \\
Y \\
Y \\
Y \\
Y \\
Y \\
Y \\
Y \\
Y \\
Y\end{array}$ & $\begin{array}{l}1 \text { wt } \% \\
1 \text { wt } \% \\
1 \text { wt } \% \\
1 \text { wt } \% \\
1 \text { wt } \% \\
1 \text { wt } \% \\
1 \text { wt } \% \\
1 \text { wt } \% \\
1 \text { wt } \% \\
1 \text { wt } \% \\
1 \text { wt } \% \\
1 \text { wt } \%\end{array}$ \\
\hline DOT & 8.5 & $\mathbf{Y}$ & $\mathbf{Y}$ & \\
\hline $\begin{array}{l}{ }^{234} \mathrm{U} \\
{ }^{235} \mathrm{U} \\
\mathrm{U} \text { (Natural) } \\
\mathrm{U} \text { (Depleted) } \\
{ }^{137} \mathrm{Cs} \\
{ }^{230} \mathrm{Th} \\
{ }^{232} \mathrm{Th}\end{array}$ & 8.6 & $\begin{array}{l}\mathrm{Y} \\
\mathrm{Y} \\
\mathrm{Y} \\
\mathrm{Y} \\
\mathrm{Y} \\
\mathrm{Y} \\
\mathrm{Y}\end{array}$ & $\begin{array}{l}\mathrm{Y} \\
\mathrm{Y} \\
\mathrm{Y} \\
\mathrm{Y} \\
\mathrm{Y} \\
\mathrm{Y} \\
\mathrm{Y}\end{array}$ & $\begin{array}{l}\mathrm{pCi} / \mathrm{g} \\
\mathrm{pCi} / \mathrm{g} \\
\mathrm{pCi} / \mathrm{g} \\
\mathrm{pCi} / \mathrm{g} \\
\mathrm{pCi} / \mathrm{g} \\
\mathrm{pCi} / \mathrm{g} \\
\mathrm{pCi} / \mathrm{g}\end{array}$ \\
\hline TOC & 8.7 & $\mathrm{Y}$ & $\mathrm{Y}$ & $50 \mathrm{ppm}$ \\
\hline
\end{tabular}

a Or any other analytical method that provides the requested constituents. 


\section{REFERENCES}

Akhter, H., Butler, L.G., Branz, S., Cartledge, F.K. and Tittlebaum, M.E. 1990.

"Immobilization of $\mathrm{As}, \mathrm{Cd}, \mathrm{Cr}$ and $\mathrm{Pb}$-Containing Soils by Using Cement or Pozzolanic Fixing Agents," Journal of Hazardous Materials 24, 145-155.

Allard, B., Eliasson, L. and Andersson, K. 1984. Sorption of Cs, I and Actinides in Concrete Systems, SKB-KBS-TR-84-15, SKB/KBS, Stockholm.

Alvarez, F.R., Lauch, R.P., Arozarena, M.M. and Allen, M.W. 1990.

"Stabilization/Solidification for Treatment of Superfund Soils," pp. 596-614 in Remedial Action, Treatment, and Disposal of Hazardous Waste, proceedings of the 16th Annual RREL Hazardous Waste Research Symposium, EPA/600/9-90/037, U.S. Environmental Protection Agency, Cincinnati, August.

Arliguie, G. and Grandet, J. 1990a. "Etude de l'hydratation du ciment en presence de zinc, influence de la teneur en gypse," Cement and Concrete Research 20, 346-354.

Arliguie, G. and Grandet, J. 1990b. "Influence de la composition d'un ciment Portland sur son hydratation en presence de zinc," Cement and Concrete Research 20, 517-524.

Atabek, R., Bouniol, P.E., Revertegat, E., Oliver, J., Gegout, P. and Jorda, M., 1990. "Nuclear Waste Immobilization in Cement-Based Materials: Overview of French Studies," pp. 3-14 in Scientific Basis for Nuclear Waste Management XIII, Materials Research Society Symposium Proceedings, Vol. 176, ed. V. M. Oversby and P. W. Brown, Materials Research Society, Pittsburgh.

Atkins, M., Beckley, N., Carson, S., Cowie, J., Glasser, F.P., Kindness, A., Macphee, D., Pointer, C., Rahman, A., Jappy, J.G., Evans, P.A., McHugh, G., Natingley, N.J. and Wilding, C. 1991. Medium-Active Waste Form Characterization: The Performance of CementBased Systems, Task 3: Characterization of Radioactive Waste Forms-A Series of Final Reports (1985-89), No. 1, EUR 13542 EN, Commission rf European Communities, Luxembourg.

Atkinson, A., Nickerson, A.K. and Valentine, T.M. 1983. The Mechanism of Leaching from Cement-Based Nuclear Wasteforms, AERE-R-10809, AERE Harwell, Oxfordshire, England, June.

Banfill, P.F. and Saunders, D.C. 1986. "The Relationship Between the Sorption of Organic Compounds on Cement ard the Retardation of Hydration," Cement and Concrete Research $16,399-410$.

Bensted, J., Callaghan, I.C., and Lepre, A. 1991. "Comparative Study of the Efficiency of Various Borate Compounds as Set-Retarders of Class G Oilwell Cement," Cement and Concrete Research 21, 663-668. 
Bernard, A. and Nomine, J.C. 1981. "Experience acquise dans le conditionnement et la lixiviabilite des dechets PWR enrobes par le ciment," presented at the Seminaire sur la Gestion des Dechets Radioactifs des Centrales Nucleaires, Karlsruhe, Federal Republic of Germany, October 5-9, 1981, IAEA-SR-57/9, Commissariat a l'Energie Atomique, CEN Saclay, France.

Bernard, A., Nomine, J.C., Cornec, G., Bonnet, A. and Farges, L. 1982. "Long-Term Leaching Tests on Full-Scale Blocks of Radioactive Wastes," Nuclear and Chemical Waste Management 3, 161-168.

Berner, U. 1990. A Thermodynamic Description of the Evolution of Pore Water Chemistry and Uranium Speciation During the Degradation of Cement, PSI-62, Paul Scherrer Institut Villigen, Switzerland, June.

Bostick, W.D., Shoemaker, J.L., Fellows, R.L., Spence, R.D., Gilliam, T.M., McDaniel, E.W. and Evans-Brown, B.S. 1988. Blast Furnace Slag-Cement Blends for the Immobilization of Technetium-Containing Wastes, K/QT-203, Oak Ridge Gaseous Diffusion Plant, Oak Ridge, Tenn., November.

Bostick, W.D., Shoemaker, J.L, Osbosne, P.E. and Evans-Brown, B. 1989. Treatment and Disposal Options for a Heavy Metals Waste Containing Soluble Technetium-99, K/QT-230-R, Oak Ridge Gaseous Diffusion Plant, Oak Ridge, Tenn., August.

Bouniol, P.E. 1987. Etude des mechanismes de piegeage du cesium par des melanges additifciment pour le conditionnement des dechets nitres, EUR 11097 FR, $C$ nmission of European Communities, Luxembourg.

Bouniol, P.E., Peyre, C.H., Mattus, A.J. and Pitt, W.W. 1988. "Preliminary Results of the Immobilization of Highly-Salt-Ladened Concentrate in Cement-Based Grout: A Joint DOE/CEA Research Effort," presented at the DOE Model Conference, Oak Ridge, Tenn., October 3-7, 1988, CEA-CONF-9688, Commissariat a l'Energie Atomique, CEN Saclay, France.

Bricka, R.M. and Cullinane, M.J. 1990. "Solidification/Stabilization as a Best Demonstrated Available Technology for Resource Conservation and Recovery Act Wastes, "pp. 437-447 in Remedial Action, Treatment, and Disposal of Hazardous Waste, proceedings of the 15th Annual Research Symposium, EPA/600/9-90/006, U.S. Environmental Protection Agency,

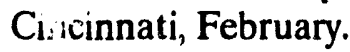

Bricka, R.M. and Hill, D.O. 1989. "Metal Immobilization by Solidification of Hydroxide and Xanthate Sludges," pp. 257-272 in Environmental Aspects of Stabilization and Solidification of Hazardous and Radioactive Wastes, ASTM STP 1033, ed. P.L. Cote and T.M. Gilliam, American Society for Testing and Materials, Philadelphia. 
Brown, T.M. and Bishop, P.L. 1985. "The Effect of Particle Size on the Leaching of Heavy Metals from Stabilized/Solidified Wastes," pp. 356-363 in Proceedings of the International Conference on New Frontiers for Hazardous Waste Management, EPA/600/9-85/025, U.S. Environmental Protection Agency, Cincinnati, September.

Brown, P.W., Harner, C.L. and Prosen, E.J. 1985. The Effect of Inorganic Salts on Tricalcium Silicate Hydration," Cement and Concrete Research 16, 17-22.

Brown, R.E., Jindal, B.S. and Bulzan, J.D. 1992. "A Critical Review of the Effectiveness of Stabilization and Solidification of Hazardous Organic Wastes," pp. 43-60 in Stabilization and Solidification of Hazardous, Radioactive, and Mixed Wastes, Vol. 2, ASTM STP 1123, ed. T.M. Gilliam and C.C. Wiles, American Society for Testing and Materials, Philadelphia.

Butler, L.G., Cartledge, F.K., Chalasani, D., Eaton, H.C, Frey, F., Tittlebaum, M.E. and Yang, S.L. 1990. "Immobilization Mechanisms in Solidification/Stabilization Using Cement/Silicate Fixing Agents," p. 557 in Remedial Action, Treatment, and Disposal of Hazardous Waste, proceedings of the 15th Annual Research Symposium, EPA/600/9-90/006, U.S. Environmental Protection Agency, Cincinnati, February.

Campbell, K.M., El-Korchi, T., Gress, D. and Bishop, P. 1987. "Stabilization of Cadmium and Lead in Portland Cement Paste Using a Synthetic Seawater Leachant," Environmental Progress 6(2), 99-103.

Cartledge, F.K., Eaton, H.C. and Tittlebaum, M. 1989. Morphology and Microchemistry of Solidified/Stabilized Hazardous Waste Systems, EPA/600/2-89/056, U.S. Environmental Protection Agency, Cincinnati, November.

Claghorn, R.D., Dodd, D.A., Rebagay, T.V. and Voogd, J.A. 1990. "Chemical and Biological Toxicity Assessment of Simulated Hanford Site Low-level Waste Grouts, " pp. 460-463 in Nuclear and Hazardous Waste Management, proceedings of Spectrum '90, Knoxville, Tenn., September 30-October 4, 1990, American Nuclear Society, LaGrange Park, Ill.

Clark, A.I., Poon, C.S. and Perry, R. 1985. "The Rational Use of Cement-Based Stabilization Techniques for the Disposal of Hazardous Wastes," pp. 339-346 in Proceedings of the International Conference on New Frontiers for Hazardous Waste Management, EPA/600/9-85/025, U.S. Environmental Protection Agency, Cincinnati, September.

Clark, D.E., Colombo, P., Doty, R.M., Fuhrmann, M. and Neilson, R.M. 1983. Leaching Properties of Solidified TRU Contaminated Incinerator Ash, BNL 33671, Brookhaven National Laboratory, Long Island, N.Y., May.

Clifton, J.R. 1991. Predicting the Remaining Service Life of Concrete, NISTIR 4712, U.S. Department of Commerce, National Instituie of Standards and Technology, Gaithersburg, Md., November.

Clifton, J.R. and Knab, L.I. 1989. Service Life of Concrete, NISTIR 89-4086, U.S. Department of Commerce, National Institute of Standards and Technology, Gaithersburg, Md., June. 
Cocke, D.L. 1990. "The Binding Chemistry and Leaching Mechanisms of Hazardous Substances in Cementitious Solidification/Stabilization Systems, "Journal of Hazardous Materials 24, 231-253.

Conner, J.R. 1990. Chemical Fixation and Solidification of Hazardous Wastes, Van Nostrand Reinhold, New York.

Conner, J.R. 1992. "Chemistry of Cementitious Solidified/Stabilized W/aste Forms," pp. 4182 in Chemistry and Microstructure of Solidified Waste Forms, ed. R.D. Spence, Lewis Publishers, Boca Raton, Fla.

Cote, P.L., Caldwell, R. and Chao, C.C. 1990. "Physical and Chemical Containment of Organic Contaminants in Solidified Wastes," Waste Management 10, 95-102.

CRC Handbook 1992. CRC Handbook of Chemistry and Physics, 73rd ed., 1992-1993, CRC Press, Boca Raton, Fla.

Cullinane, M.J., Bricka, R.M. and Francingues, N.R. 1987. "An Assessment of Materials that Interfere with Stabilization/Solidification Processes," pp. 64-68 in Land Disposal, Remedial Action, Incineration and Treatment of Hazardous Waste, proceedin rs of the Thirteenth Annual Rescarch Symposium, May 6-8, 1987, Cincinnati, EPA/6 -87/015, ed. J.F. Martiny and N.P. Barkley, U.S. Environmental Protection Agency, Cincin i.ati, July.

Daimon, M. 1980. "Mechanism and Kinetics of Slag Cement Hydration," pp. III-2/1»10 in Proceedings of the 7th International Congress on the Chemistry of Cement, Vol. I, Septima, Paris, 1980.

Davis, R.C. and C ， D.L. 1991. "Analysis of the Physical and Chemical Aspects of Leaching Behavio: Lead and Chromium-Doped Portland Cement," presented at the 5th International Symposium on Ceramics in Nuclear and Hazardous Waste Management, Cincinnati, April 28-May 2, 1991, WSRC-MS-91-072, Westinghouse Savannah River Company, Aiken, S.C.

De Angelis, G., Marchetti, A. and Balzamo, S. 1992. "Leach Studies: Influence of Various Parameters on the Leachability of Cesium from Cemented BWR Evaporator Concentrates," pp. 182-192 in Stabilization and Solidification of Hazardous, Radioactive and Mixed Wastes, Vol. 2, STP 1123, ed. T.M. Gilliam and C.C. Wiles, American Society for Testing and Materials, Philadelphia.

de Percin, P.R. 1990. "Results from the Stabilization Technologies Evaluated by the SITE Program," pp. 648-660 in Proceedings of the New England Environmental Expo, Hynes Convention Center, April 10-12, 1990, EPA/600/D-90/232, U.S. Environmental Protection Agency, Cincinnati. 
Dole, L.R. 1985. "Overview of the Applications of Cement-Based Immobilization Technologies Developed at U.S. DOE Facilities," pp. 455-465 in Waste Management '85, Vol. 2, proceedings of the Symposium on Waste Management held at Tucson, Ariz., March 24-28, 1985, CONF-850314-62, ed. R.G. Post.

Fischer, D.F. and Johnson, T.R. 1988. Immobilization of IFR Salt Wastes in Mortar, CONF-880903-45, Argonne National Laboratory, Argonne, Ill.

Fuhrmann, M. and Colombo, P. 1989. "Radionuclide Releases from Cement Waste Forms in Seawater," Radioactive Waste Management and the Nuclear Fuel Cycle 11(4), 365-380.

Gegout, P., Revertegat, E. and Moine, G. 1992. "Action of Chloride Ions on Hydrated Cement Pastes: Influence of the Cement Type and Long-Term Effect of the Concentration of Chlorides," Cement and Concrete Research 22, 451-457.

Ghorab, H.Y., Hilal, M.S. and Antar, A. 1990. "Effect of Mixing and Curing Waters on the Behaviour of Cement Pastes and Concrete. Part II: Properties of Cement Paste and Concrete," Cement and Concrete Research 20, 69-72.

Gilliam, T.M. and J.A. Loflin. 1986. "Leachability Studies of Hydrofracture Grouts," ORNL/TM-9879, Oak Ridge National Laboratory, Oak Ridge, Tenn., November.

Gilliam, T.M., Spence, R.D., Evans-Brown, B.S, Morgan, I.L, Shoemaker, J.L. and Bostick, W.D. 1988. "Performance Testing of Blast Furnace Slag for Immobilization of Technetium in Grout," pp. 109-111 in Spectrum '88, proceedings of the American Nuclear Society International Topical Meeting on Nuclear and Hazardous Waste Management, September 11, 1988, Pasco, Wash., CONF-880903-17, American Nuclear Society, La Grange Park, Ill.

Gilliam, T.M., Hutchins, D.A and Chodak, P. in press. Final Waste-Form Development Project: Performance Criteria for Phase I Treatability Studies, to be published as ORNL/TM-12699, Oak Ridge National Laboratory, Oak Ridge, Tenn.

Glasser, F.P. 1992. "Progress in the Immobilization of Radioactive Wastes in Cement," Cement and Concrete Research 22, 201-216.

Glasser, F.P., Rahman, A.A., Macphee, D., McCulloch, C.E. and Angus, M.J. 1985. Immobilization of Radioactive Waste in Cement Based Matrices, PECD/DOE/RW/85.063, University of Aberdeen, Old Aberdeen, Scotland, June.

Glasser, F.P., Diamond, S. and Roy, D.M. 1987. "Hydration Reactions in Cement Pastes Incorporating Fly Ash and Other Pozzolanic Materials," pp. 139-158 in Fly Ash and Coal Conversion By-products: Characterization, Utilization and Disposal III, proceedings of a symposium held December 1-3, 1986, Boston, Materials Research Society Symposium Proceedings, Vol. 86, ed. G.J. McCarthy, F.P. Glasser, D.M. Roy, and S. Diamond, Materials Research Society, Pittsburgh. 
Greenhalgh, W.O. 1986. "The Immobilization of Organic Liquid Wastes," in Waste Management '86, March 2-6, 1986, Tucson, Ariz., HEDL-SA-3377-FP, Hanford Engineering Development Laboratory, Richland, Wash., August.

Grosse, D.W. 1991. "Review of Treatment for Hazardous Waste Streams," pp. 541-611 in Encyclopedia of Environmental Control Technology, Volume 4: Hazardous Waste Containment and Treatment, ed. P.N. Cheremisinoff.

Grutzeck, M.W. 1989. Physical Chemistry of Portland-Cement Hydrate, Radioactive-Waste Hosts, DOE/ER/45145-4, Pennsylvania State University, University Park.

Habayeb, M.A. 1985. "Leaching Performance of Cemented Decontamination Wastes," Nuclear and Chemical Waste Management 5, 305-314.

Heimann, R.B., Conrad, D., Florence, L.Z, Neuwirth, M., Ivey, D.G., Mikula, R.J. and Lam, W.W. 1992. "Leaching of Simulated Heavy Metal Waste Stabilized/Solidified in Different Cement Matrices," Joumal of Hazardous Materials, 31, 39-57.

INEL 1992 (Idaho National Engineering Laboratory, EG\&G Idaho, Inc.). Mixed and LowLevel Waste Treatment Facility Project, Volume 3: Waste Treatment Technologies, EGG-WMO-10244/Vol. 3, Idaho National Engineering Laboratory, Idaho Falls, April.

Jacobs, J.H. 1992. "Treatment and Stabilization of a Hexavalent Chromium Containing Waste Material," Environmental Progress 11(2), 123-126.

Jeffrey, J., Garner, L. and House, W. 1991. "Cement as a Stabilization Media," pp. 359-363 in Waste Management 91, Vol. II, proceedings of the Symposium on Waste Management held at Tucson, Ariz., February 24-28, 1991, ed. R. G. Post.

Jennings, H.M., Taleb, H., Frohnsdorff, G. and Clifton, J.R. 1986. "Interpretation of the Effects of Retarding Admixtures on Pastes of $\mathrm{C}_{3} \mathrm{~S}, \mathrm{C}_{3}$ A Plus Gypsum, and Portland Cement," pp. 239-243 in Proceedings 8th International Congress on the Chemistry of Cement, Theme 2.1, Vol. III, Rio de Janeiro.

Jones, L.W. 1990. Interferences Mechanisms in Waste Stabilization/Solidification Processes, EPA/600/2-89/067, U.S. Army Engineers Waterways Experiment, Vicksburg, Miss., January.

Jones, L.W., Bricka, R.M. and Cullinane, M.J. 1992. "Effects of Selected Waste Constituents on Solidified/Stabilized Waste Leachability," pp. 193-203 in Stabilization and Solidification of Hazardous, Radioactive, and Mixed Wastes, Vol. 2, ASTM STP 1123, ed. T.M. Gilliam and C.C. Wiles, American Society for Testing and Materials, Philadelphia.

Kass, M.D. and Lefort, H.G. 1991. Reduction in Nitrate Leaching from a Cement Waste-Form by Using Waterproofing Admixture Additions, Y/DZ-742, Oak Ridge Y.12 Plant, Oak Ridge, Tenn., June. 
Kertesz, C.J., Chevanas, P.R., Auffret, L. and Biagini, A. 1991. "Conditioning of Alpha Incinerator Ash by Means of Embedding in Different Matrices," pp. 85-96 in Treatment and Conditioning of Radioactive Incinerator Ashes, CEA-CONF-10292, ed. L. Cecille and K. Kertesz, Elsevier Applied Science.

Kertesz, C.J., Chenavas, P.R. and Naud, G.M. 1990. "The Starting Up of a Pilot Plant for Rad:oactive Incinerator Ash Conditioning-Results of Two Embedding Campaigns," presented at Waste Management 90, Tucson, Ariz., February 25-March 1, 1990, CEACONF-10283, Commissariat a l'Energie Atomique, CEN Saclay, France.

Kim, J.H., Kim, H.Y., Park, H.H. and Suh, I.S. 1992. "Cementation of Borate Waste by Adding Slaked Lime," pp. 338-347 in Stabilization and Solidification of Hazardous, Radioactive and Mixed Wastes, Vol. 2, ASTM STP 1123, ed. T.M. Gilliam and C.C. Wiles, American Society for Testing and Materials, Philadelphia.

Kolvites, B. and Bishop, P. 1989. "Column Leach Testing of Phenol and Trichloroethylene Stabilized/Solidified with Portland Cement," pp. 238-250 in Environmental Aspects of Stabilization and Solidification of Hazardous Radioactive Wastes, ASTM STP 1033, ed. P.L. Cote and T.M. Gilliam, American vociety for Testing and Materials, Philadelphia.

Kumar, A. and Roy, D.M. 1986. "Retardation of $\mathrm{Cs}^{+}$and $\mathrm{Cl}^{-}$Diffusion Using Blended Cement Admixtures," Journal of the American Ceramic Society 69(4), 356-360.

Kumar, A., Komarneni, S. and Roy, D.M. 1987. "Diffusion of $\mathrm{Cs}^{+}$and $\mathrm{Cl}^{-}$through Sealing Materials," Cement and Concrete Research 17, 153-160.

Lameille, J.M., Chiappini, R., Goutiere, G., Petit, J.C. and Regourd, M. 1986. "Relation entre la lixiviation d'elements traces $(\mathrm{Cs}, \mathrm{Sr}$ et $\mathrm{Co}$ ) et la microstructure au cours du vieillissement d'un mortier a base de CPA," communication presented at the 8th International Congress on Cement Chemistry, Rio de Janeiro, September 22-27, 1986, CEACONF-8558, Commissariat a l'Energie Atomique, CEN Saclay, France.

Langton, C.A. 1989. "Slag-Based Materials for Toxic Metals and Radioactive Waste Stabilization," presented at 3rd Annual International Conference on the Use of Fly Ash, Slag and Silica Fume in Concrete, Trondheim, Norway, June 19-24, 1989, DP-MS-87-95-Rev. 2, Savannah River Laboratory, Aiken, S.C.

Langton, C.A., Dukes, M.D. and Simmons, R.V. 1983. "Cement-Based Waste-Forms for Disposal of Savannah River Plant Low-Level Radioactive Salt Waste," presented at the Materials Research Society Annual Meeting, Boston, November 14-17, 1983, CONF-831174-61, E. I. Du :'ont de Nemours, Savannah River Laboratory, Aiken, S.C.

LDR FFCA 1992. "Federal Facility Compliance for Storage of Radioactive Mixed Waste Subject to Land Disposal Restrictions for the Oak Ridge Reservation in Oak Ridge, Tennessee," Docket 92-02 FFR, June 12, 1992, USEPA Region IV/DOE-Oak Ridge. 
Lea, F.M. 1971. The Chemistry of Cement and Concrete, Chemical Publishing Company, Inc., New York.

Lee, D.J, Howard, C.G. and Price, M.S. 1986. "Development of a Cement Encapsulation Process for Spent Powdered Ion Exchange Materials," pp. 112-121 in Spectrum '86, proceedings of the American Nuclear Society International Topical Meeting on Waste Management and Decontamination and Decommissioning, September 14-18, 1986, Niagara Falls, N.Y., CONF-860905-Vol. 1, ed. J.M. Pope, I.M. Leonard, and E.J. Mayer, American Nuclear Society, La Grange Park, Ill.

Lokken, R.O. 1992a. Heat of Hydration of Double-Shell Slurry Feed Grouts, PNL-7860, Pacific Northwest Laboratory, Richland, Wash.

Lokken, R.O. 1992b. Heat of Hydration of Simulated 106-AN Grouts, PNL-7859, Pacific Northwest Laboratory, Richland, Wash.

Lokken, R.O., Martin, P.F.C., Bowen, W.M., Harty, H. and Treat, R.L. 1987. Variability in Properties of Grouted Phosphate/Sulfate N-Reactor Waste, PNL-6030, Pacific Northwest Laboratory, Richland, Wash., January.

Lomenick, T.F. 1990. Proceedings of the Workshop on Radioactive, Hazardous, and/or Mixed Waste Sludge Management, December 4-6, 1990, Knoxville, Tenn., CONF-901264, Oak Ridg. K-25 Site, Oak Ridge, Tenn.

McDaniel, E.W., Morgan, M.T., Moore, J.G., Devaney, H.E. and Dole, L.R. 1982. Strontium Leachability of Hydrofracture Grouts for Sludges-Slumies, ORNL/TM-8198, Oak Ridge National Laboratory, Oak Ridge, Tenn., March.

McVay, C.W., Stimmel, J.R. and Marchetti, S. 1989. "WVNS Experience with Cement Solidification of Decontaminated Spent Fuel Waste," pp. 41-56 in Proceedings of Workshop on Cement Stabilization of Low-level Radioactive Waste, Gaithersburg, Maryland, May 31-June 2, 1989, NUREG/CP-0103, ed. P.R. Reed, U.S. Nuclear Regulatory Commission, Washington, D.C.

McWhinney, H.G. and Cocke D.L. 1993. "A Surface Study of the Chemistry of Zinc, Cadmium, and Mercury in Portland Cement," Waste Management 13, 117-123.

McWhinney, H.G., Cocke, D.L., Balke, K. and Ortego, J.D. 1990. “An Investigation of Mercury Solidification and Stabilization in Portland Cement Using X-Ray Photoelectron Spectroscopy and Energy Dispersive Spectroscopy," Cement and Concrete Research 20, 79. 91.

Malek, R.I., Roy, D.M. and Fang, Y. 1988. Pore Structure Permeability, and Chloride Diffusion in Fly-Ash and Slag Containing Pastes and Mortars, "Pore Structure and Permeability of Cementitious Materials, proceedings of a symposium held November 28-30, 1988, Boston, Materials Research Society Symposium Proceedings, Vol. 137, ed. L.R. Roberts and J.P. Skalny, Materials Research Society, Pittsburgh. 
Mattus, A.J., Gilliam, T.M. and Dole, L.R. 1988. Review of EPA, DOE and NRC Regulations on Establishing Solid Waste Performance Criteria, ORNL/TM-9322, Oak Ridge National Laboratory, Oak Ridge, Tenn., July.

Metcalf \& Eddy, Inc. 1991. Handbook-Stabilization Technologies for RCRA Corrective Actions, EPA/625/6-91/026, U.S. Environmental Protection Agency, Cincinnati, August.

Mollah, M.Y., Tsai, Y.N., Hess, T.R. and Cocke, D.L. 1992. "An FTIR, SEM and EDS Investigation of Solidification/Stabilization of Chromium Using Portland Cement Type V and Type IP," Journal of Hazardous Materials 30, 273-283.

Muhua, T. and Roy, D.M. 1987. "An Investigation of the Effect of Organic Solvent on the Rheological Properties and Hydration of Cement Paste," Cement and Concrete Research 17, 983-994.

Myers, T.E. and Zappi, M.E. 1992. "Laboratory Evaluation of Stabilization/Solidification Technology for Reducing the Mobility of Heavy Metals in New Bedford Harbor Superfund Site Sediment," pp. 304-319 in Stabilization and Solidification of Hazardous, Radioactive, and Mixed Wastes, Vol. 2, ASTM STP 1123, ed. T.M. Gilliam and C.C. Wiles, American Society for Testing and Materials, Philadelphia.

Ortego, J.D. 1990. "Spectroscopic and Leaching Studies of Solidified Toxic Metals," Journal of Hazardous Materials 24, 137-144.

Ortego, J.D., Jackson, S., Yu, G.S, McWhinney, H. and Cocke, D.L. 1989. "Solidification of Hazardous Substances-A TGA and FTIR Study of Portland Cement Containing Metal Nitrates," Journal of Environmental Sciences and Health A24(6), 589-602.

Ouyang, C., Nanni, A and Wen, F. 1988. "Internal and External Sources of Sulfate Ions in Portland Cement Mortar: Two Types of Chemical Attack," Cement and Concrete Research 18, 699-709.

Palmer, J.D. and Smith, D.L.G. 1986. The Incorporation of Low and Medium Level Radioactive Wastes (Solids and Liquids) in Cement, EUR 10561 EN, Commission of European Communities, Luxembourg.

Petersen, R.D., Johnson, A.J. and Peter, K.G. 1986. Nitrate Salt Immobilization Process Development and Implementation, RFP-3919, Rockwell International, Rocky Flats Plant, Golden, Colo.,, November.

Ping, X. and Beaudoin, J.J. 1992. "Mechanism of Sulphate Expansion, I. Thermodynamic Principle of Crystallization Pressure," Cement and Concrete Research 22, 631-640.

Plecas, I.B., Peric, A.D., Drljaca, J.D., Kostadinovic, A.M. and Glodic, S.D. 1992. "Immobilization of Radioactive Waste Water Residues in a Cement Matrix," Cement and Concrete Research 22, 571-576. 
Plodinec, M.J., 1977. Evaluation of Cs-137 Sorbents for Fixation in Concrete, DP-1444, E. I. Du Pont de Nemours, Savannah River Laboratory, Aiken, S.C., January.

Pollard, S.J., Montgomery, D.M., Sollars, C.J. and Perry, R. 1991. “Organic Compounds in the Cement-Based Stabilization/Solidification of Hazardo s Mixed Wastes-Mechanistic and Process Consideration," Journal of Hazardous Materials 28, 313-327.

Poon, C.S. and Perry, R. 1987. "Studies of Zinc, Cadmium and Mercury Stabilization in OPC/PFA Mixtures," in pp. 67-76 in Fly Ash and Coal Conversion By-products:

Characterization, Utilization and Disposal III, Materials Research Society Symposium Proceedings, Vol. 86, ed. G.J. McCarthy, F.P. Glasser, D.M. Roy, and S. Diamond, Materials Research Society, Pittsburgh.

Poon, C.S., Peters, C.J., Perry, R., Barnes, P. and Barker, A.P. 1985. "Mechanism of Metal Stabilization by Cement-Based Fixation Processes," Science of the Total Environment 41, $55-71$.

Poon, C.S., Clark, A.I., Perry, R., Barker, A.P. and Barnes, P. 1986. "Permeability Study on the Cement-Based Solidification Process for the Disposal of Hazardous Wastes," Cement and Concrete Research 16, 161-172.

Pottier, P.E. and Glasser, F.P. 1986. Characterization of Low and Medium-Level Radioactive Waste Forms: Final Report, 2nd Program, 1980-1984, EUR 10579 EN, Commission of European Communities, Luxembourg.

Rebagay, T.V. and Dodd, D.A. 1989. "Leach Characterization of Phosphate-Sulphate Waste Grouts," presented at the Annual Meeting of the American Chemical Society, Dallas, April 9-14, 1989, WHC-SA-0466, Westinghouse Hanford Company, Richland, Wash., March.

Regourd, M. 1982. "L'hydratation du ciment Portland," pp. 193-221 in Le beton hydraulique, Presses de l'Ecole Nationale des Ponts et Chaussees, Paris.

Regourd, M. 1987. "Microstructure of Cement Blends Including Fly Ash, Silica Fume, Slag and Fillers," pp. 185-197 in Fly Ash and Coal Conversion By-product: Characterization, Utilization and Disposal III, proceeding of a symposium held Decer .r 1-3, 1986, Boston, Materials Research Society Symposium Proceedings, Vol. 86, ed. G... McCarthy, F.P. Glasser, D.M. Roy, and S. Diamond, Materials Research Society, Pittsburgh.

Riaz, M. and Zamorani, E. 1989. "A Study of the Effects of 1,3,5-Trichlorobenzene Solidified in Cement," Cement and Concrete Research 19, 124-130.

Roy, D.M. 1986. "Mechanisms of Cer:' nt Paste Degradation Due to Chemical and Physical Factors," pp. 362-380 in Proceedings \& .nternational Congress on the Chemistry of Cement, Vol. I, Rio de Janeiro. 
Sams, T.L., McDaniel, E.W., Tallent, O.K, Francis, C.L. and Washburn, F.A. 1988.

Formulation Studies and Grout Development for Fixation of Variable Phosphate/Sulfate Waste, ORNL/TM-10291/R1, Oak Ridge National Laboratory, Oak Ridge, Tenn., February.

Sell, N.J., Revall, M.A., Bentley, W. and McIntosh, T.H. 1992. "Solidification and Stabilization of Phenol and Chlorinated Phenol Contaminated Soils," pp. 73-85 in Stabilization and Solidification of Hazardous, Radioactive, and Mixed Wastes, Vol. 2, ASTN. STP 1123, ed. T.M. Gilliam and C.C. Wiles, American Society for Testing and Materials, Philadelphia.

Shin, H.S., Kim, J.O., Koo, J.K. and Shin, E.B. 1992. "Mixture Design Optimization Considering Three Disposal Options for Solidified Heavy Metal Sludges" pp. 283-296 in Stabilization and Solidification of Hazardous, Radioactive and Mixed Wastes, Vol. 2, ASTM STP 1123, ed. T.M. Gilliam and C.C. Wiles, American Society for Testing and Materials, Philadelphia.

Shukla, S.S., Shukla, A.S., Lee, K.C., Aminabhair, T.M. and Balundgi, R.H. 1992. "Solidification/Stabilization Study for the Disposal of Pentachlorophenol," Jourral of Hazardous Materials 30, 317-331.

Singh, N.B. , Singh, A.K. and Singh, S.P. 1986a. "Effect of Citric Acid on the Hydration of Portland Cement," Cement and Concrete Research 16, 911-920.

Singh, N.B., Singh, S.P. and Singh, A.K. 1986b. "Effect of Lactic Acid on the Hydration of Portland Cement," Cement and Concrete Research 16, 545-553.

Skalny, J.P. and Young, J.F. 1980. "Mechanisms of Portland Cement Hydration," pp. II1/3-45 in Proceedings of the 7th International Congress on the Chemistry of Cement, Vol. I, Septima, Paris.

Spence, R.D. and Osborne, S.C. 1993. Literature Review of the Stabilization/Solidification of Volatile Organic Compounds and the Implications for Hanford Grouts, ORNL/TM-11824, Oak Ridge National Laboratory, Oak Ridge, Tenn., September.

Spence, R.D., Gilliam, T.M., Morgan, I.L. and Osborne, S.C. 1992.

"Stabilization/Solidification of Wastes Containing Volatile Organic Compounds in Commercial Cementitious Waste Forms," pp. 61-72 in Stabilization and Solidification of Hazardous, Radioactive, and Mixed Wastes, Vol. 2, ASTM STP 1123, ed. T.M. Gilliam and C.C. Wiles, American Society for Testing and Materials, Philadelphia.

Spence, R.D., McDaniel, E.W., Anderson, C.M., Lokken, R.O. and Piepel, G.F. 1993. Development of Grout Formulations for 106-AN Waste: Mixture-Experiment Results and Analysis, Vol. 1: Narrative and Recommendations, ORNL/TM-12437/V1, Oak Ridge National Laboratory, Oak Ridge, Tenn., September.

Stegeman, J.A. and Cote, P.L. 1990. "Summary of an Investigation of Test Methods for Solidified Waste Evaluation," Waste Management 10, 41-52. 
Stinson, M.K. and Sawyer, S. 1989. "In Situ Stabilization/Solidification of PCB-Contaminated Soil," pp. 151-160 in Proceedings of the 3rd International Conference on New Frontiers for Hazardous Waste Management, EPA/600/9-89/072, U.S. Environmental Protection Agency, Cincinnati.

Tallent, O.K., McDaniel, E.W., Del Cul, G.D., Dodson, K.E and Trotter, D.R. 1988. "Immobilization of Technetium and Nitrate in Cement-Based Materials," pp. 23-32 in Scientific Basis for Nuclear Waste Management XI, proceedings of the Materials Research Society Symposium, Boston, November 30-December 3, 1987, Materials Research Symposium Proceedings, Vol. 112, ed. M.J. Apted and R.E. Westerman, Materials Research Society, Pittsburgh.

Tallent, O.K., McDaniel, E.W., Del Cul, G.D., Dodson, K.E. and Trotter, D.R. 1989. Development of Immobilization Technology for Hanford Double-Shell Slumy Feed Waste, ORNL/TM-10906, Oak Ridge National Laboratory, Oak Ridge, Tenn., August.

Tashiro, C., Takahashi, H., Kanaya, M., Hirakida, J., and Yoshide, R. 1977. "Hardening Property of Cement Mortar Adding Heavy Metal Compound and Solubility of Heavy Metal from Hardened Mortar," Cement and Concrete Research 7, 283-290.

Tashiro, C., Oba, J. and Akama, K. 1979. "The Effects of Several Heavy Metal Oxides on the Formation of Ettringite and the Microstructure of Hardened Ettringite," Cement and Concrete Research 9, 303-308.

Taylor, H.F.W. 1986. "Chemistry of Cement Hydration," pp. 82-110 in Proceedings 8th International Congress on the Chemistry of Cement, Vol. I/2.1, Rio de Janeiro.

Taylor, H.F.W. 1990. Cament Chemistry, Academic Press, London.

Thomas, N.L., Jameson, D.A. and Double, D.D. 1981. "The Effect of Lead Nitrate on the Early Hydration of Portland Cement," Cement and Concrete Research 11, 143-153.

Tittlebaum, M.E., Cartledge, F.K., Chalasani, D., Eaton, H. and Walsh, M. 1985. "A Procedure for Characterizing Interactions of Organics with Cement: Effects of Organics on Solidification/Stabilization," pp. 328-336 in Proceedings: International Conference on New Frontiers for Hazardous Waste Management, EPA/600/9-85/025, U.S. Environmenta! Protection Agency, Cincinnati, September.

Torstenfelt, B. and Hedin, G. 1989. "Leaching of Cesium from a Cement Matrix," pp. 495-500 in Scientific Basis for Nuclear Waste Manugemenı XII, Materials Research Society Symposium Proceedings, Vol. 127, ed. W. Lutze and R.C. Ewing, Materials Research Society, Pittsburgh.

Toste, A.P. 1984. Potential Effects of Onganics on the Performance of Grouted Nuclear Wastes. PNL Milestone 39, 10/3/84, Facific Northwest Laboratory, Richland, Wash., September. 
Troxell, G.E., Davis, H.E. and Kelly, J.W. 1968. Composition and Properties of Concrete, 2nd ed., McGraw-Hill Book Company, New York.

Trussell, S. and Spence, R.D. 1993. Feasibility Study on the Solidification of Liquid Low-Level Mixed Waste in the Inactive Tank System at Oak Ridge National Laboratory, Oak Ridge, Tennessee, ORNL/ER-142, Oak Ridge National Laboratory, Oak Ridge, Tenn., January.

U.S. DOE 1993. U.S. Department of Energy Strategic Plan for the Treatment of Appendix B Wastes, DOE/OR-1083, Revision 0, February 12, 1993.

U.S. EPA 1989. Stabilization/Solidification of CERCLA and RCRA Wastes: Physical Tests, Chemical Testing Procedures, Technology Screening, and Field Activities. EPA/625/6-89/022, U.S. Environmental Protection Agency, Cincinnati, May.

U.S. NRC 1989. Proceedings of the Workshop on Cement Stabilization of Low-Level Radioactive Waste Held at Gaithersburg, Maryland, May 31-June 2, 1989, NUREG/CP-0103, ed. P.R. Reed, U.S. Nuclear Regulatory Commission, Washington, D.C., October.

Vejmelka, P. and Sambell, R.A.J. 1984. Characterization of Low and Medium-Level Radioactive Waste Forms: Joint Annual Progress Report, 1982, EUR 9423 EN, Commission of European Communities, Luxembourg.

Vidick, B., Fletcher, P. and Michaux, M. 1989. "Evolution at Early Hydration Times of the Chemical Composition of Liquid Phase of Oil-Well Cement Pastes with and Without Additives. Part II. Cement Pastes Containing Additives," Cement and Concrete Research 19, 567-578.

Vipulanandan, C. and Krishnan, S. 1990. "Solidification/Stabilization of Phenolic Waste with Cementitious and Polymeric Materials," Journal of Hazardous Materials 24, 123-136.

Walter, M.B., Serne, R.J., Johnstone, D.L. and Yonge, D.R. 1988. "Chemical Characterization, Leach and Adsorption Studies of Solidified Low-Level Wastes," Nuclear and Chemical Waste Management 8, 55-67.

Walton, J.C., Plansky, L.E. and Smith, R.W. 1990. Models for Estimation of Service Life of Concrete Barriers in Low-Level Radioactive Waste Disposal, NUREG/CR-5542, U.S. Nuclear Regulatory Commission, Washington, D.C., September.

Way, S.J. and Shayan, A. 1989. "Early Hydration of Portland Cement in Water and Sodium Hydroxide Solutions: Composition of Solutions and Nature of Solid Phases, "Cement and Concrete Research 19, 759-769.

Wiles, C.C. and Barth, E. 1992. "Solidification/Stabilization: Is It Always Appropriate?" pp. 18-32 in Stabilization and Solidification of Hazardous, Radioactive and Mixed Wastes, Vol. 2, ASTM STP 1123, ed. T.M. Gilliam and C.C. Wiles, American Society for Testing and Materials, Philadelphia. 
Wilhite, E.L. 1986. "Waste Salt Disposal at the Savannah River Plant," pp. 157-162 in Spectrum '86, proceedings of the American Nuclear Society International Topical Meeting on Waste Management and Decontamination and Decommissioning, September 14-18, 1986, Niagara Falls, N.Y., CONF-860905-Vol. 1, ed. J.M. Pope, I.M. Leonard, and E.J. Mayer, American Nuclear Society, La Grange Park, Ill.

Xuequan, W., Sheng, Y., Xiadong, S., Mingshu, T. and Liji, Y. 1991. "Alkali-Activated Slag Cement Based Radioactive Waste Forms," Cement and Concrete Research 21, 16-20.

Young, J.F. 1972. "A Review of the Mechanisms of Set-Retardation in Portland Cement Pastes Containing Organic Admixtures," Cement and Concrete Research 2, 415-433.

Zamorani, E., Sheikh, I.A., Della Rossa, M. and Serrini, G. 1989. "Physical Properties and Leachability of an MLW Stream Containing $\mathrm{Cr}, \mathrm{Ni}$, and $\mathrm{Cd}$ Immobilized in a Cement Matrix," pp. 489-494 in Scientific Basis for Nuclear Waste Management XII, Materials Research Society Symposium Proceedings, Vol. 127, ed. W. Lutze and R.C. Ewing, Materials Research Society, Pittsburgh.

Zhou, H. and Colombo, P. 1984. "Solidification of Radioactive Waste in a Cement/Lime Mixture," pp.163-168 in Waste Management '84, Vol. 2, proceedings of the Symposium on Waste Management held at Tucson, Arız., March 11-15, 1984, ed. R.G. Post. 


\section{INTERNAL DISTRIBUTION}

1-5. T. J. Abraham

6. P. M. Backus

7. M. L. Baker

8. C. E. Benson

9-10. J. B. Berry

11. A. Bleier

12 G. F. Boris

13. W. D. Bostick

14. C. H. Brown, Jr.

15. C. E. Buttram

16. C. M. Cecala

17-21. T. B. Conley

22. A. G. Croff

23. L. R. Dole

24. T. L. Donaldson

25. P. L. Flowers

26. C. L. Francis

27. C. E. Frye

28. R. K. Genung

29. V. P. Gilbert

30-39. T. M. Gilliam

40. J. Gilpin

41. H. W. Godbee

42. A. H. Gorin

43. J. R. Hightower

44-46. D. A. Hutchins

47. R. R. Kimmet

48. R. A. Krabill

49. D. K. Little

50. A. P. Malinauskas
51. A. J. Mattus

52-56. C. H. Mattus

57. E. W. McDaniel

58. W. S. McGarvey

59. L. J. Mezga

60. I. L. Morgan

61. M. I. Morris

62. R. W. Morrow

63. C. M. Noakes

64. J. J. Perona

65. S. M. Robinson

66. T. O. Rogers

67. R. J. Sams

68. D. P. Schaefferkoetter

69. R. D. Spence

70. L. H. Stinton

71. T. N. Ternes

72. D. R. Trotter

73. H. P. Wayland, Jr.

74. D. D. West

75. J. E. Williams

76. B. V. Wojtowicz

77. Central Research Library

78. ORNL Y-12 Technical Library Document Reference Section

79. Laboratory Records - RC

80-81. Laboratory Records

82. ORNL Patent Section

\section{EXTERNAL DISTRIBUTION}

83. Doug Allen, Radian Corp., 120 S. Jefferson, Oak Ridge, TN 37830

84. Ed S. Alperin, IT Corporation, 312 Directors Drive, Knoxville, TN 37923

85. Bill Batchelor, Texas A\&M University, Dept. of Civil Engineering, College Station, TX 77803

86. E. A. Burns, S-Cubed, Environmental Technology Sector, P.O. Box 1620, La Jolla, CA 92038-1620 
87. J. C. Griess, 10803 Fox Park Road, Knoxville, TN 37931

88. Larry W. Jones, Univ. of Tennessee, Waste Management Inst., 428 S. Stadium Hall, Knoxville, TN 37996-0710

89. Ian L. Pegg, Vitreous State Laboratory, Hannan Hall, 620 Michigan Avenue, NE, Washington, DC 20064

90-91. Bob Petersen, EET, 129-A Perimeter Park Road, Knoxville, TN 37922

92. S. K. Rutherford, Westinghouse Environmental Management Company of Ohio, P.O. Box 398704, Cincinnati, OH 45239-8704

93. Barry E. Scheetz, Pennsylvania State University, Materials Research Lab., University Park, PA 16802

94. Julia A. Stegemann, Wastewater Technology Centre, P.O. Box 5068, Burlington, Ontario L7R-4L7, Canada

95. William Webb, Radian Corp., 120 S. Jefferson Circle, Oak Ridge, TN 37830

96-97. Office of Scientific and Technical Information, P.O. Box 62,Oak Ridge, TN 37831

\section{DOE HEADQUARTERS}

98. Tom Russell, U.S. Department of Energy, 10 Great Pines, Rockville, MD 20850

99. R. P. Whitfield, U.S. Department of Energy, EM-40, 1000 Independence Ave., S.W., Washington, DC 20585

\section{DOE FIELD OFFICES}

100-109. L. W. Clark, DOE-ORO, P.O. Box 2001, Oak Ridge, TN 37831

110. David M. Corden, DOE-ORO, P.O. Box 2001, Oak Ridge, TN 37831

111. R. L. Egli, Energy Research and Development, DOE-ORO, P.O. Box 2001, Oak Ridge, TN 37831-8600

112. Clifford Hsieh, DOE-ORO, SE-34, P.O. Box 2001, Oak Ridge, TN 37831

113. G. R. Hudson, ORO-AMCE, P.O. Box 2001, Oak Ridge, TN 37831

114. Tony Manion, DOE-ORO, P.O. Box 2001, Oak Ridge, TN 37831

115. R. C. Sleeman, DOE-ORO, P.O. Box 2008, Room 2116, Oak Ridge, TN 37831

116. Gene Turner, DOE, Box A, Aiken, SC 29802

117. Byron D. Walker, DOE, K-25 Site Office, P.O. Box 2003, Oak Ridge, TN 37831-7136

118. Office of Assistant Manager, Energy Research and Development, DOE-ORO, P.O. Box 2001, Oak Ridge, Tennessee 37831 


\section{OTHER FEDERAL AGENCIES}

119. J. J. Barich, U.S. Environmental Protection Agency, 1200 Sixth Avenue, Seattle, WA 98101

120. John M. Cullinane, Jr., USACE Waterways Experiment Station, 3909 Halls Ferry Road, Vicksburg, MS 39180-6199

121. Patricia Erickson, U.S. Environmental Protection Agency, 26 W. Martin Luther King Drive, Cincinnati, OH 45268

122. T. T. Holmes, U.S. Army Corps of Engineers, Waterways Experiment Station, P.O. Box 631, Vicksburg, MS 39180

123. Robert E. Shewmaker, U.S. Nuclear Regulatory Commission, 5-E-4, Washington, DC 20555

124. Carlton Wiles, RREL-EPA, 5995 Center Hill Dr., Cincinnati, OH 45224

\section{OTHER M\&O CONTRACTORS}

125. Dan Armstrong, Westinghouse, Savannah River Plant, Aiken, SC 29802

126. Chuck Baldwin, EG\&G-Rocky Flats Plant, P.O. Box 928, Golden, CO 80402-0464

127. J. Bradford, EG\&G Idaho, Inc., P. O. Box 1625, Idaho Falls, ID 83415-2109

128. Harcourt Bull III, Westinghouse, 704Z, Savannah River Plant, Aiken, SC 29802

129. Ken Burgard, Westinghouse, P.O. Box 1970, MS-R4-03, Richland, WA 99352

130. Wu-Ching Cheng, Sandia National Laboratory, P.O. Box 5800, Albuquerque, NM 87185-5800

131. Peter Colombo, Brookhaven National Laboratory, 50 Rutherford, Bldg. 703, Upton, NY 11973

132. Mel Cowgill, Brookhaven National Laboratory, Bldg. 830, Upton, NY 11973

133. G. Ross Darnell, EG\&G Idaho, Inc., P.O. Box 1625, MS-2424, Idaho Falis, ID 83415-2424

134. J. L. Epstein, Westinghouse Hanford Company, P.O. Box 1970, Richland, WA 99352

135. Andrea Faucette, Rocky Flats Plant, P.O. Box 928, Golden, CO 80402-0464

136. Joe Fortier, Westinghouse, Savannah River Laboratory, Aiken, SC 29802

137. E. C. Garcia, EG\&G, P.O. Box 1625, Idaho Falls, ID 83415

138. Bradley M. Gardner, EG\&G Idaho, Inc., P.O. Box 1625, Idaho Falls, ID 83402

139. Rod Gimple, Westinghouse, Box 398704, Cincinnati, OH 45239

140. John H. Heiser, Brookhaven National Laboratory, 50 Rutherford, Bldg. 703, Upton, NY 11973-5000

141. Carol Janzen, Westinghouse Savannah River Company, P.O. Box 616, Aiken, SC 29802

142. C. L. Jensen, EG\&G, Bldg. 776, Golden, CO 80402-0464 
143. A. J. Johnson, EG\&G Rocky Flats, P. O. Box 464, Golden, CO 80402-0464

144. Paul D. Kalb, Brookhaven National Laboratory, Env. \& Waste Tech. Center, Bldg. 830, Upton, NY 11973

145. Richard Kent Farnsworth, EG\&G Idaho, Inc., Office of Waste Tech. Develop., P.O. Box 1625, Idaho Falls, ID 83415-3710

146. C. A. Langton, Westinghouse Savannah River Company, P.O. Box 616, Aiken, SC 29802

147. J. W. Liskowitz, Institute for Hazardous and Toxic Waste Management, New Jersey Institute of Technology, Newark, NJ 07102

148. R. O. Lokken, Battelle, Pacific Northwest Laboratories, Battelle Boulevard, Richland, WA 99352

149. John W. Mandler, INEL, P.O. Box 1625, Idaho Falls, ID 83415

150. Charles E. McDonald, Westinghouse Hanford Company, P.O. Box 1970, MS H1-60, Richland, WA 99352

151. M. A. Mihalic, Westinghouse-Hanford, Box 1970, L4-88, Richland, WA 99352

152. Dean Nester, Westinghouse, P.O. Box 1970, Richland, WA 99352

153. Paul Pak, USDOE-Richland Operations Office, Environmental Restoration Div., MS-85-19, Richland, WA 99352

154. Thomas R. Pauly, Hanford, P.O. Box 1970, Richland, WA 99352

155. Richard Peters, Battelle, Pacific Northwest Laboratories, Battelle Boulevard, Richland, WA 99?52

156. Gary Piepel, Battelle, Pacific Northwest Laboratories, Battelle Boulevard, Richland, WA 99352

157. N. R. Quick, EG\&i3, P.O. Box 464, Bldg. 881, Golden, CO 80402

158. Barry Siskind, Brookhaven National Laboratory, Bldg. 830, Upton, NY 11973

159. Dennis Thompson, Savannah River Plant, Bldg. 704Z, Aiken SC 29802

160. G. W. Veazey, Los Alamos National Laboratory, P. O. Box 1663, MS E524, Los Alamos, NM 87545

161. J. A. Voogd, Westinghouse Hanford Company, P. O. Box 1970, Richland, WA 99352

162. John Veil, Argonne National Laboratory, 370 L'Enfant Promenade, Suite 702, Washington, DC 20024

163. T. G. Weiss, WB\&S, West Valley Nuclear Services, P.O. Box 191, West Valley, NY 14171

164. F. R. Weitz, Savannah River Laboratory, P.O. Box 616, Aiken, SC 29801

165. Michelle Wells, Savannah River Plant, Bldg. 704Z, Aiken, SC 29802 


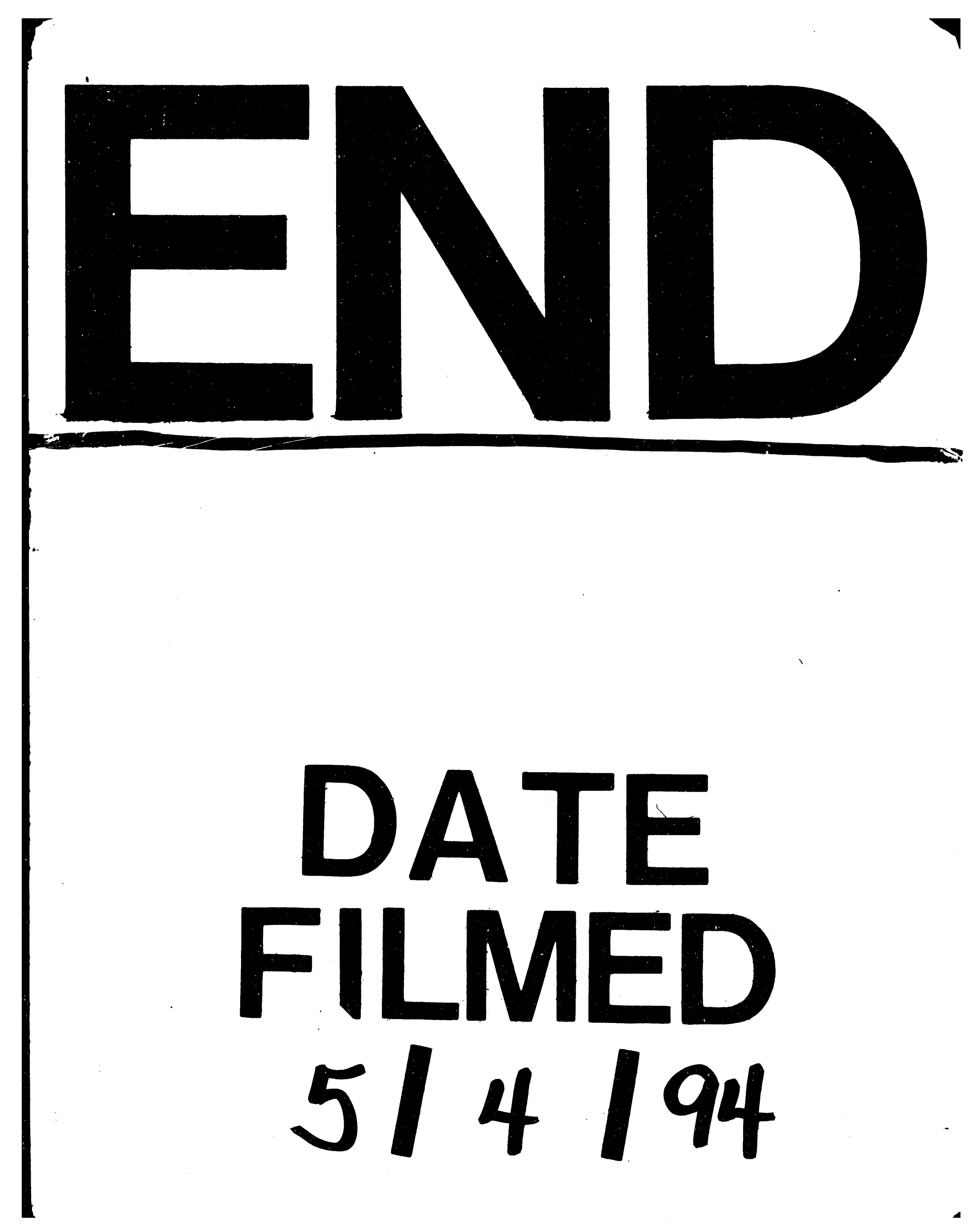


